Érika de Paula Lins

\title{
Tutor, professor ou suporte virtual? Um estudo sobre a construção da identidade profissional no contexto da Educação a Distância
}

Dissertação de Mestrado

Dissertação apresentada ao Programa de PósGraduação em Educação da PUC-Rio como requisito parcial para obtenção do título de Mestre em Educação.

Orientadora: Prof. a Gilda Helena Bernardino de Campos

Rio de Janeiro

Março de 2016 
Érika de Paula Lins

\section{Tutor, professor ou suporte virtual? Um estudo sobre a construção da identidade profissional no contexto da Educação a Distância}

Dissertação apresentada como requisito parcial para obtenção do grau de Mestre pelo Programa de PósGraduação em Educação do Departamento de Educação do Centro de Teologia e Ciências Humanas da PUC-Rio. Aprovada pela comissão Examinadora abaixo assinada.

Prof. a Gilda Helena Bernardino de Campos

Orientadora

Departamento de Educação - PUC-Rio

Profa Magda Pischetola

Departamento de Educação - PUC-Rio

Profa Lígia Silva Leite Faculdade de Educação - UERJ

Prof ${ }^{\mathrm{a}}$ Denise Berruezo Portinari Coordenadora Setorial do Centro de Teologia e Ciências Humana PUC-Rio

Rio de Janeiro, 31 de março de 2016. 
Todos os direitos reservados. É proibida a reprodução total ou parcial do trabalho sem autorização da universidade, da autora e do orientador.

\section{Érika de Paula Lins}

Pedagoga, especialista em Planejamento, Implementação e Gestão da Educação a Distância (UFF) e em Psicopedagogia e Orientação Educacional (UFRRJ). Orientadora Educacional pela Prefeitura Municipal de Cabo Frio desde 2006. Atua também como professora horista na Universidade Estácio de Sá em Cabo Frio, no curso de Pedagogia, e como tutora a distância das disciplinas pedagógicas do CEDERJ/UAB.

Ficha Catalográfica

Lins, Érika de Paula.

Tutor, professor ou suporte virtual? Um estudo sobre a construção da identidade profissional no contexto da Educação a Distância / Érika de Paula Lins; orientadora: Gilda Helena Bernardino de Campos. - 2016.

140 f.: il.(color.); $30 \mathrm{~cm}$

Dissertação (mestrado)-Pontifícia Universidade Católica do Rio de Janeiro, Departamento de Educação, 2016.

Inclui bibliografia

1. Educação - Teses. 2. Tutoria. 3. Docência. 4. Educação à distância. 5. Identidade. I. Campos, Gilda Helena Bernardino de. II. Pontifícia Universidade Católica do Rio de Janeiro. Departamento de Educação. III. Título. 
Aos meus pais, dona Suely e seu José, pelo apoio incondicional ao longo da minha trajetória para alcançar o título de mestre. 


\section{Agradecimentos}

A Deus por ter me fortalecido em todas as etapas do mestrado, me dando todo o amparo espiritual para a conclusão deste trabalho.

Aos meus queridos irmãos Évila e Emílio, pelo incentivo e encorajamento.

Ao meu cunhado Gustavo, pela força e pelo exemplo de vida e superação.

À minha querida orientadora Gilda Campos, pela atenção, acolhimento, ensinamentos e contribuições ao longo da pesquisa. Você me inspira!

Aos colegas da CCEAD pelo apoio, pelas trocas e por todo o aprendizado.

Ao meu grande amigo e incentivador Marcos Antonio Silva, pelos ensinamentos como ex-professor e coordenador de curso.

Aos meus coordenadores e amigos do CEDERJ/UFRRJ, Marco Antonio de Moraes, Ramofly Bicalho, Suemy Yukizaki e Benjamin Pinto, pelo apoio e incentivo para cursar o mestrado.

Aos professores da Banca examinadora da minha dissertação, pelas preciosas contribuições.

Aos meus amigos do início da minha trajetória acadêmica, Danielle Lima Tavares, Danielle Aguiar, Vera Lúcia Aguiar e Janilson Castelo, que me incentivaram a seguir em frente na realização deste sonho.

Aos meus colegas de trabalho da Estácio-Cabo Frio, pelo apoio de sempre. Em especial, à professora Mônica Infante, pela preciosa ajuda no Abstract.

Aos meus colegas da Escola Municipal Prof. Zélio Jotha, pelo apoio carinhoso ao longo do mestrado. 
Aos meus amigos do CEDERJ/UFRRJ, pela parceria de sempre, especialmente aos tutores do curso de Administração, que participaram da pesquisa respondendo o questionário.

Ao CEDERJ, pelo aprendizado e experiência concedida ao longo dos meus nove anos de tutoria.

Aos meus amigos da turma do mestrado, pela parceria, cooperação, amizade e por todo aprendizado construído ao longo das disciplinas e dos encontros marcantes fora da PUC. Em especial Élio Portella, Carolyna Barroca, Roberta Pitta, João Paulo Cabrera, Larissa Naumann, Jéssica Castro, Ângela Souza, Dimas Martorello, Rosa Pires, Liliane Albuquerque, Carla Maria, Elisa Motta, Calu Silveira, Joyci Barcellos e Cintia Costa. Amizade eterna!

Ao meu querido amigo Rômulo Casciano, pelo exemplo de vida, dedicação, postura acadêmica e generosidade. Obrigada pela ajuda com o Survey Monkey e o SPSS. Você é um dos melhores presentes que a PUC me deu. Obrigada por existir na minha vida.

A todos os professores do Programa de Pós-Graduação em Educação da Pontifícia Universidade Católica do Rio de Janeiro, pelas preciosas contribuições para a minha formação.

À Pontifícia Universidade Católica do Rio de Janeiro, pela concessão da bolsa VRAC, que permitiu que eu cursasse o mestrado em um Programa de PósGraduação de excelência.

Muito obrigada. 


\section{Resumo}

Lins, Érika de Paula; Campos, Gilda Helena Bernardino de. Tutor, professor ou suporte virtual? Um estudo sobre a construção da identidade profissional no contexto da Educação a Distância. Rio de Janeiro, 2016. 140p. Dissertação de Mestrado - Departamento de Educação, Pontifícia Universidade Católica do Rio de Janeiro.

A transformação da Educação a Distância nos dias atuais, impulsionada pelas inovações tecnológicas, demanda novas práticas educativas. A interação com os alunos é elemento fundamental nesse processo, tornando a figura do tutor essencial para o desenvolvimento dos alunos. O tutor, entretanto, não possui uma identidade profissional e nem atividades reconhecidas pelas instituições de ensino. Este trabalho teve como objetivo analisar e compreender a identidade profissional dos tutores. Buscou-se identificar o perfil e as percepções desses profissionais sobre o papel que exercem e a definição das atividades de tutoria, partindo de questões como: “A identidade do tutor na Educação a Distância se constrói buscando uma aproximação com a docência ou se estabelece no viés burocráticoadministrativo?”. "Quais são as principais características que compõem o perfil do tutor no que se refere aos aspectos gerais e de formação?". "Quais são as percepções que o tutor possui acerca do lugar que ele ocupa na Educação a Distância?”. "Qual a relação entre os documentos oficiais que fazem referência à tutoria no Brasil e a construção da identidade do tutor?". Para responder a estas questões, um questionário foi aplicado para 117 tutores. O questionário foi composto por 23 perguntas fechadas, analisadas com o auxílio do software SPSS, mais duas perguntas abertas, estudadas através da análise de conteúdo. Os resultados revelaram um perfil de tutores especialistas em EAD com outros vínculos de trabalho, que se sentem desvalorizados e se percebem como docentes frente a uma legislação que evidencia o distanciamento entre tutoria e docência.

\section{Palavras-chave}

Tutoria; Docência; Educação a distância; Identidade 


\section{Abstract}

Lins, Érika de Paula; Campos, Gilda Helena Bernardino de. (Advisor). Tutor, teacher or virtual support? A study on the construction of professional identity in the context of the Distance Education. Rio de Janeiro, 2016. 140p. MSc. Dissertation - Departamento de Educação, Pontifícia Universidade Católica do Rio de Janeiro.

The modification of the Distance Education today, driven by technological innovation, demands new educational practices. Interaction with students is a key element in this process, making the figure of the tutor essential to the development of students. The tutor, however, does not have a professional identity and activities recognized by educational institutions. This study aims to analyze and understand the professional identity of the tutors. It sought to identify the profile and perceptions of these professionals about their role and the definition of mentoring activities, from questions such as "The identity of the tutor in The Distance Education is built by seeking an approach to teaching or is settled in bureaucratic and administrative bias?". "What are the main features that compose the tutor's profile with regard to the general aspects and training?". "What are the perceptions the tutor has about the his place in Distance Education?". "What is the relationship between the official documents the construction of the tutor's identity?". To answer these questions, a questionnaire was applied to 117 tutors. The questionnaire consisted of 23 closed questions, analyzed with the SPSS software, plus two open questions, studied through content analysis. The results revealed a profile of expert tutors in Distance Education with other professional work, a tutor who feels devalued and they perceive themselves as teachers concerning to legislation. The study points to the gap between mentoring and teaching.

\section{Keywords}

Tutoring; Teaching; Distance Education; Identity 


\section{Sumário}

\section{Introdução}

Sobre o caminho percorrido para a construção do objeto 15

1.1 Justificativa 17

1.2 Questões da pesquisa 18

$\begin{array}{ll}1.3 \text { Objetivos da pesquisa } & 19\end{array}$

1.4 Procedimentos metodológicos 20

1.5 Estrutura da dissertação 21

2. O processo de expansão da Educação a Distância no Brasil: um breve histórico 24

2.1 O Consórcio CEDERJ/Fundação Cecierj: conhecendo um pouco da sua história 28

2.2 A Universidade Aberta do Brasil: um breve relato 31

3. Tutor, professor ou suporte virtual?

Uma análise conceitual da identidade do tutor 36

3.1 Tutoria presencial e a distância: especificidades da função do tutor 43

3.2 Competências necessárias para o exercício da função do tutor $\quad 46$

3.3 Tutoria versus docência à luz da legislação da

Educação a Distância: diálogos, limites e tensões. 53

4. A opção metodológica 67

4.1 A seleção da amostra 68

4.2 A construção e validação do questionário aplicado 69

4.3. Análise dos dados: afinal, quem é o tutor? 73

4.3.1 Descrição e análise quantitativa: perfil do tutor, experiência profissional e formação acadêmica 74

4.3.2. Descrição e análise quantitativa: características relacionadas à experiência dos tutores

4.3.3 Descrição e análise quantitativa: percepções do tutor sobre o lugar que ele ocupa na Educação a Distância

4.3.3.1 As percepções dos tutores sobre o lugar que eles ocupam na Educação a Distância à luz da análise fatorial 
4.3.4 Descrição e análise qualitativa: sobre a relevância e a profissionalização da função do tutor

4.3.4.1 A importância do tutor para o ensino a distância 101

4.3.4.2 As competências necessárias para o exercício da tutoria $\quad 103$

4.3.4.3 A tutoria e o processo de precarização na EaD 105

4.3.4.4 Tutoria e docência: limites, tensões e possibilidades $\quad 107$

4.1.5 Você acredita que ser tutor (a) é profissão? 109

5. Apontamentos finais: algumas respostas encontradas 114

6. Referências 122

7. Apêndices 132

Apêndice A: Tabelas das respostas sobre o item: "Comente algo que você considere relevante na sua função como tutor". 132 Apêndice B: Bloco final - Tabelas das respostas das perguntas abertas "Você acredita que ser tutor é uma profissão"? 133

Anexo A: Tabelas das respostas sobre o item: "Comente algo que você considere relevante na sua função como tutor".

Anexo B: Bloco final - Tabela das respostas das perguntas abertas "Você acredita que ser tutor é uma profissão"? 


\section{Lista de Tabelas e Quadros}

Quadro 01 - Características das atividades dos tutores. 45

Quadro 02 - Quadro teórico das competências dos tutores. 49

Quadro 03 - Atribuições dos tutores presenciais do CEDERJ 58

Quadro 04 - Atribuições dos tutores a distância do CEDERJ 59

Quadro 05 - Quadro teórico das questões 71

Tabela 01 - Função dos tutores respondentes $\quad 74$

Tabela 02 - Formação dos tutores respondentes $\quad 75$

Tabela 03 - Formação específica em EAD 76

Tabela 04 - Cursos realizados pelos tutores $\quad 77$

Tabela 05 - Tempo de trabalho na tutoria em EAD 78

Tabela 06 - Outras atividades profissionais exercidas 79

Tabela 07 - Sobre o Projeto Político-Pedagógico do curso 81

Tabela 08 - Matriz de correlação $\quad 94$

Tabela 09 - Matriz de comunalidades das variáveis 95

Tabela 10 - Matriz de componentes $\quad 97$

Tabela 11 - Frequência temática das respostas 100 


\section{Lista de Figuras e gráficos}

Figura 01 - Constituição do funcionamento do sistema UAB 34

Gráfico 01 - Matrículas no Sistema UAB no período de 2007-2013 33

Gráfico 02 - Faixa etária dos tutores $\quad 75$

Gráfico 03 - Faixa etária dos tutores respondentes 74

Gráfico 04 - Sobre a interação com os alunos 74

Gráfico 05 - Percepções dos tutores sobre o lugar que eles ocupam na Educação a Distância $\quad 87$

Gráfico 06 - Variância total dos fatores 96

Gráfico 07 - Rotação espacial 97 


\section{Lista de abreviaturas}

ABED - Associação Brasileira de Educação a Distância

CD - Conselho Deliberativo

CAPES - Coordenação de Aperfeiçoamento de Pessoal de Nível Superior CECIERJ - Fundação Centro de Ciências e Educação Superior a

Distância do Estado do Rio de Janeiro

CEDERJ - Centro de Educação Superior a Distância do Estado do Rio de Janeiro

CAPES - Coordenação de Aperfeiçoamento de Pessoal de Nível Superior CEJAS - Centros de Educação de Jovens e Adultos

EaD - Educação a Distância

FNDE - Fundo Nacional de Desenvolvimento da Educação

INEP - Instituto Nacional de Estudos e Pesquisas Educacionais-Anísio

Teixeira

IES - Instituições de Ensino Superior

LDBEN - Lei de Diretrizes e Bases da Educação Nacional

MEC - Ministério da Educação

PPGE PUC-Rio - Programa de Pós-Graduação em Educação da

Pontifícia Universidade Católica do Rio de Janeiro

SECT - Secretaria de Estado de Ciência e Tecnologia

SEED - Secretaria de Educação a Distância

SPSS - Statistical Package for the Social Sciences

UAB - Universidade Aberta do Brasil

VRAC - Bolsas de isenção de pagamento de mensalidades escolares 
Partimos do princípio que a compreensão desse "profissional" no conjunto dos trabalhadores docentes da EaD é condição essencial para análises em torno das suas competências principais, das tecnologias que ele utiliza, dos males que podem acometer sua saúde, da sua logística de trabalho, da sua concepção sobre aspectos agradáveis ou desagradáveis do trabalho na EaD. (MILL; FIDALGO, 2007). 


\section{Introdução: sobre o caminho percorrido para a construção do objeto}

Algumas questões que envolvem o universo da Educação a Distância ${ }^{1}$ acompanham as minhas indagações e reflexões, desde que comecei a desenvolver um trabalho de tutoria nos cursos de licenciatura do Consórcio CEDERJ/UFRRJ ${ }^{2}$, em 2006, especificamente nas disciplinas pedagógicas dos cursos de licenciatura em Física, Química, Matemática, Ciências Biológicas, História, Geografia e Turismo. Além desse vínculo de trabalho, passei por dois $\operatorname{cursos}^{3}$ de especialização, que fomentaram as minhas indagações, levantando outras questões sobre o universo do ensino virtual.

Nessa mesma direção, ingressei no Mestrado em Educação Brasileira do Programa de Pós-Graduação em Educação da Pontifícia Universidade, onde as questões levantadas em minha trajetória na Educação a Distância foram amadurecendo e receberam a delimitação necessária para a composição do meu objeto de pesquisa.

Dentro dessa trajetória cabe também destacar a relevância das contribuições das disciplinas cursadas no Mestrado em Educação Brasileira da PUC/Rio, especificamente, a disciplina Políticas para a Educação a Distância ${ }^{4}$, na qual as

\footnotetext{
1 Utilizarei neste trabalho a definição do termo de Educação a Distância que se encontra no Decreto do Ministério da Educação, de ${ }^{\circ}$ 5.622: Art. $1^{\circ}$ Para os fins deste Decreto, caracteriza-se a Educação a Distância como modalidade educacional na qual a mediação didático-pedagógica nos processos de ensino e aprendizagem ocorre com a utilização de meios e tecnologias de informação e comunicação (2005). Cabe também destacar que o termo "Educação a Distância" será apresentado neste trabalho com as iniciais grafadas em letras maiúsculas, no sentido de evidenciar a relevância que a Educação a Distância vem assumindo no cenário educacional brasileiro.

2 Consórcio CEDERJ/UFRRJ - Centro de Ciências e Educação Superior a Distância do Estado do Rio de Janeiro em parceria com a Universidade Federal Rural do Rio de Janeiro. Trata-se de um consórcio entre as instituições públicas de Ensino Superior do Estado do Rio, que buscam oferecer diferentes cursos de graduação na modalidade a distância. O Consórcio entre o CEDERJ é composto pelo CEFET, UENF, UERJ, UFF, UFRJ, UFRRJ e UNIRIO.

$3 \mathrm{O}$ primeiro curso se refere à Especialização em Psicopedagogia e Orientação Educacional na Universidade Federal Rural do Rio de Janeiro, concluído em 2006. O segundo curso oferecido pela UFF, foi de Especialização em Planejamento, Implementação e Gestão da Educação a Distância, concluído em 2011.

4 Ministrada pela professora Gilda Helena B. de Campos.
} 
discussões temáticas proporcionaram reflexões fundamentais sobre as estruturas políticas que organizam essa modalidade de ensino, corroborando para o levantamento e análise de alguns documentos legais ${ }^{5}$ que regem a Educação a Distância no Brasil e se relacionam com o trabalho de tutoria no âmbito da Educação a Distância.

Ao mesmo tempo, o meu interesse pela Educação a Distância e a construção da identidade do tutor ganhou força quando ingressei no grupo de pesquisa Cooperação e Avaliação em Educação a Distância. A participação nas reuniões do grupo se constituiu num campo fértil, contribuindo de forma significativa para o delineamento desta pesquisa.

Em meio aos temas em debate atualmente no campo da Educação, o impacto das atividades na Educação a Distância e a sua relação com o trabalho docente têm merecido destaque nas pesquisas educacionais. Estudos recentes como SANTOS; WINCHUAR (2014), SANTOS et. al. (2014), NUNES (2013), MENDES (2013), MILL; FIDALGO (2007), VILLARDI; OLIVEIRA (2005), entre outros, apontam para a preocupação com a qualidade dessa modalidade de ensino, considerando a sua expansão no cenário educacional brasileiro.

Ao mesmo tempo, a trajetória da Educação a Distância vem sendo construída por muitas transformações nos últimos anos, acarretando em modificações nas práticas educativas nesse formato de ensino, em que o processo de aprendizagem assume um papel decisivo para a formação dos alunos. Utilizamse recursos vinculados à tecnologia que, por sua vez, buscam garantir a verificação da aprendizagem dos alunos. Entretanto, apesar da Educação a Distância utilizar a tecnologia como ponto central do seu processo de aprendizagem, ela não se distancia do objetivo central do modelo de educação presencial: a formação do aluno.

As peculiaridades do mundo virtual ao qual essa modalidade de ensino pertence demarcam fortemente o seu espaço, corroborando para o surgimento de novas estratégias de ensino e novas ferramentas de aprendizagem, culminando na reformulação dos processos de mediação do conhecimento. Nesse contexto, a

5 Decreto-Lei $\mathrm{n}^{\circ} 5.622$ que regulamenta o credenciamento de instruções para oferta de cursos e programas na modalidade a distância, os Referenciais de Qualidade para Educação Superior a Distância (2007), a Resolução CD/FNDE (2009) e o Regimento Interno da Fundação Centro de Ciências e Educação Superior a Distância do Estado do Rio de Janeiro (2010). 
interação com os alunos aparece como um fator decisivo, abrindo espaço para o surgimento da figura do tutor dentro desse cenário.

A partir de tais discussões que se referem à expansão da Educação a Distância no Brasil, o presente estudo pretende discutir as práticas desenvolvidas pelo tutor no universo da Educação a Distância, tendo como objeto de análise a compreensão da figura do tutor, suas especificidades e o delineamento da sua identidade profissional.

Para se referir ao ator central desse estudo, adotamos o conceito de tutor, uma vez que os Decretos e Leis que foram discutidos ao longo do texto utilizam a palavra "tutor" para designar as atribuições que lhe cabem, muito embora o conceito sofra variações e, em alguns cursos e estudos sejam chamados por outras nomenclaturas. Ao mesmo tempo, utilizarei a definição de SCHMID (2004) sobre o conceito de tutor, uma vez que ele define esse ator como aquele que estabelece o contato com o aluno no universo virtual para, "através de uma relação pessoal, facilitar a este o desenvolvimento de todo o seu potencial intelectual e comunicacional" (p.278).

\section{1. \\ Justificativa}

O propósito de investigar a construção da identidade profissional do tutor se justifica, na medida em que o tutor ainda não possui um lugar delimitado dentro do processo de ensino e aprendizagem a distância. Percebe-se algumas pesquisas no campo da Educação a Distância que apontam para o crescimento dessa modalidade de ensino no Brasil, fazendo com que o trabalho de tutoria, mesmo sem uma delimitação clara, emerja como um elo crucial entre os alunos e o processo de ensino-aprendizagem nos cursos a distância, reforçando a necessidade de um entendimento mais amplo sobre este ator no processo.

Nesse contexto, percebe-se que a questão envolvendo a identidade do tutor representa uma problemática que precisa ser estudada, considerando os múltiplos e distintos papéis que lhe são atribuídos nos diferentes cursos e instituições, interferindo na compreensão da sua identidade e enfraquecendo a legitimação da sua função. 
Conhecer as especificidades do papel do tutor se configura como algo necessário para que ele consiga desempenhar o seu papel frente ao processo de ensino-aprendizagem nos cursos a distância. Sobre essa necessidade, NUNES (2013) destaca que:

\begin{abstract}
Mas para que um tutor exerça sua função a contento, em primeiro lugar ele e as demais pessoas envolvidas no curso devem conhecer bem o seu papel. Porém, instituições diferentes atribuem, geralmente, papéis distintos aos tutores. Dentro de uma mesma instituição, os cursos podem, também, apresentar essa diversidade. E, inclusive, dentro de um mesmo curso (p. 2).
\end{abstract}

Nessa mesma direção, VILLARDI (2005) reforça a necessidade de estudos sobre a temática:

\begin{abstract}
A questão da tutoria é, nesse momento, uma das mais relevantes a ser estudada e abordada, uma vez que a observação de alguns processos de formação, via $\mathrm{EaD}$, vem apontando a atuação do tutor como decisiva para o sucesso da iniciativa e permanência do aluno até o final do curso (p. 440).
\end{abstract}

Dessa maneira, esta pesquisa se configura como mais uma possibilidade de ampliar a discussão sobre o tema, buscando contribuir na legitimação do trabalho do tutor no cenário da educação a distância. Além disso, a opção por pesquisar o papel do tutor na Educação a Distância ganha força à medida que esta função possui uma série de atribuições que são consideradas fundamentais para o pleno funcionamento dos cursos.

\title{
1.2.
}

\section{Questões da pesquisa}

No que se refere à questão central do projeto, pretende-se responder a seguinte pergunta: a identidade do tutor na Educação a Distância se constrói buscando uma aproximação com a docência ou se estabelece no viés burocráticoadministrativo?

Ao mesmo tempo, a questão central fomentou a construção de outras perguntas, que estarão colaborando para uma compreensão mais clara do que se busca responder: 
- Quais são as principais características que compõem o perfil do tutor no que se refere aos aspectos gerais e de formação?

- Quais são as percepções que o tutor possui acerca do lugar que ele ocupa na Educação a Distância?

- Qual a relação entre os documentos oficiais que fazem referência à tutoria no Brasil e a construção da identidade do tutor?

É importante destacar que o conceito de docência neste estudo está associado ao papel exercido pelo professor nas diferentes formas dos processos educativos. Partimos da definição de GATTI (2009), que entende o professor como elemento indispensável aos processos educativos, independente da modalidade de ensino, no que se fere ao exercício de práticas docentes com vistas:

(...) a criação/produção/revisão/recomposição dos materiais didáticos, até aos contatos com os alunos, mais diretos ou indiretos, em diferentes momentos, por diferentes modalidades: na colocação de temas, de problemas, em consultas, em tutoria, em revisões, em processos de recuperação, etc.; por e-mails, por webcam, por telefone, em bases de atendimento, etc. (GATTI, 2009, p. 91).

Nesse sentido, entendemos a docência como o exercício das práticas docentes do professor nas diferentes modalidades de ensino, sendo discutida neste estudo no âmbito da modalidade a distância.

\section{3.}

\section{Objetivos da pesquisa}

Este estudo tem como objeto a análise e compreensão da figura do tutor e o delineamento de sua identidade profissional. Discute as práticas desenvolvidas por ele no universo da Educação a Distância, uma vez que ainda não houve avanços frente à compreensão das suas atividades e, consequentemente, na compreensão da sua identidade profissional. Além disso, a partir deste estudo discutimos os objetivos específicos a seguir:

- Apresentar as principais características dos tutores, buscando delinear o perfil do grupo pesquisado, a fim de identificar, a partir dos dados coletados, os elementos que vão auxiliar na compreensão sobre os principais aspectos da identidade do tutor, relacionadas à docência e atividades administrativas; 
- Descrever a percepção dos tutores frente à sua identidade e a visão que possuem sobre o locus que ocupam na Educação a Distância.

- Relatar e discutir os principais achados e sobre o que diz a legislação frente a construção da identidade do tutor.

\section{4.}

\section{Procedimentos metodológicos}

Adotamos para o desenvolvimento metodológico para este trabalho a abordagem qualitativa, com delineamento exploratório-descritivo, considerando que o nosso objeto de análise ainda carece de estudos e discussões no campo da pesquisa em Educação, pois trata-se "de uma nova classe de trabalhadores ainda não compreendida suficientemente: os tutores virtuais" (MILL et.al, 2010, p. 75).

O caráter exploratório e descritivo se justifica nos seguintes objetivos da pesquisa: (1) Identificar as principais características da identidade do tutor do curso de Administração do CEDERJ/UFRRJ; (2) Identificar as percepções que o tutor possui acerca do lugar que ocupa na Educação a Distância, uma vez que "entre as pesquisas descritivas, salientam-se aquelas que têm por objetivo estudar as características de um grupo" (GIL, 2002, p. 41).

Além disso, a pesquisa bibliográfica também fez parte do delineamento metodológico desta pesquisa, a partir dos livros e artigos científicos que abordam o tema, assim como das fontes das leis e Decretos relacionados à Educação a Distância e a função do tutor de modo a contribuir na busca de informações para as respostas das questões levantadas neste estudo.

Esta pesquisa considera que a abordagem qualitativa não rejeita as múltiplas formas de quantificação, uma vez que os métodos qualitativos e quantitativos podem ser adotados como métodos complementares (DEMO, 2001).

Nesse sentido, organizamos os procedimentos metodológicos da seguinte forma:

- Revisão de literatura sobre estudos teóricos a respeito do tutor;

- Revisão de literatura sobre questões, características, métodos e práticas em tutoria na modalidade a distância;

- Elaboração de um quadro referente às atividades da tutoria; 
- Seleção do campo de estudo;

- Elaboração do questionário da pesquisa;

- Seleção da amostra para a pesquisa;

- Painel de especialistas para a validação do questionário;

- Seleção de ferramenta online para a aplicação do questionário;

- Aplicação do questionário;

- Tabulação dos dados colhidos pelo questionário;

- Análise dos resultados da tabulação;

- Retorno à literatura e ao quadro de características a fim de analisar as respostas ao questionário aplicado à amostra do quadro de competências e características elaborado anteriormente;

- Redação dos resultados da pesquisa.

\section{5 .}

\section{A estrutura da dissertação}

A dissertação está estruturada em cinco capítulos. No primeiro capítulo, organizamos a introdução, apresentando as questões de estudo, objetivos e a justificativa do trabalho.

O segundo capítulo apresenta um breve panorama sobre as políticas públicas para Educação a Distância, voltando o nosso olhar para a expansão do Ensino Superior no Brasil a partir do surgimento do Consórcio CEDERJ e da Universidade Aberta do Brasil.

No terceiro capítulo apresentamos uma discussão teórica sobre a construção da identidade do tutor, passando pela análise conceitual do conceito de identidade a partir dos estudos de DUBAR (1997), TARDIF; RAYMOND (2000) e MILL; FIDALGO (2007), partindo da ideia de que a construção da identidade profissional passa pelo processo de socialização e se constrói por intermédio das relações estabelecidas entre os sujeitos. Em outro tópico deste capítulo, adentramos nas principais características do tutor em âmbito presencial e a distância, assim como também elencando as principais competências presentes em suas ações tutoriais tendo como pano de fundo os Referenciais de Qualidade para a Educação Superior a Distância (2007) e os estudos de TENÓRIO et. al. (2015), NUNES (2013), CASTRO (2013), MENDES (2013), MILL et. al (2008), 
ALONSO (2010), MACHADO; MACHADO, CAMPOS; AMARAL (2007), (2004) e SILVA (2008).

$\mathrm{Na}$ seção final deste capítulo, apresentamos uma análise de alguns materiais que regem e norteiam a Educação a Distância no Brasil, tendo como objetivo um entendimento amplo sobre a identidade do tutor e o papel que ele ocupa no universo da Educação a Distância, assim como a sua aproximação com a docência. Para tanto, utilizamos os seguintes materiais:

- O Decreto n ${ }^{\circ} 5.622$ de 19 de dezembro de 2005, que regulamenta o art. 80 da Lei $\mathrm{n}^{\circ}$ 9.394, de 20 de dezembro de 1996;

- O Decreto $n^{\circ}$ 6.303, de 12 de dezembro de 2007, que apresenta alterações nos dispositivos do Decreto $\mathrm{n}^{\circ}$ 5.622;

- Os Referenciais de Qualidade para Educação Superior a Distância (2007);

- A Resolução do Conselho Deliberativo (CD) / Fundo Nacional de Desenvolvimento da Educação - FNDE (2009);

- O Regimento interno da Fundação Centro de Ciências e Educação Superior a Distância do Estado do Rio de Janeiro (2010);

- A Convenção Coletiva (2014) firmada entre o Sindicato dos Professores do Município do Rio de Janeiro (SIMPRO-RIO) e o Sindicato das Entidades Mantenedoras de Estabelecimento de Ensino Superior do Estado do Rio de Janeiro (SEMERJ) - que discutem as atribuições e o regime de trabalho do tutor a distância;

- O Instrumento de Avaliação Externa (2010) utilizado pelas comissões avaliadoras das Instituições de Ensino Superior (presenciais e a distância);

- O Instrumento de Avaliação Externa (2014) utilizados pelas comissões avaliadoras das Instituições de Ensino Superior (presencial).

- Edital para seleção de Tutores para os cursos de graduação do Consórcio CEDERJ. Fundação Cecierj (2015);

- O Projeto de Lei n ${ }^{\circ}$ 2435/2011 - Dispõe sobre a regulamentação do exercício da atividade de Tutoria em Educação a Distância.

O quarto capítulo se divide em duas partes: a primeira está voltada para a apresentação da metodologia escolhida para o desenvolvimento da pesquisa e 
apresenta as etapas da construção, aplicação e análise do questionário. Na segunda parte, apresentamos os resultados dessa dissertação, no sentido de responder aos objetivos e questões desta pesquisa.

No quinto e último capítulo são apresentados apontamentos sobre os achados da pesquisa, em relação às questões de estudo e propondo novos olhares sobre o tema. 


\section{2 \\ O processo de expansão da Educação a Distância no Brasil: um breve histórico}

Nos últimos anos, devido aos avanços tecnológicos e sua relação direta com a educação, os cursos a distância passaram a ganhar mais espaço, como podemos perceber nos estudos da Associação Brasileira de Educação a Distância (ABED) e nos relatórios do $\operatorname{INEP}^{6}$. No relatório analítico publicado no ano de 2014, a ABED aponta um aumento significativo nas matrículas de alunos nessa modalidade de ensino, que alcançou um total de 692.279 alunos matriculados.

Segundo os dados fornecidos pelo INEP, o Censo da Educação Superior de 2013 apontou que os três cursos mais procurados na modalidade a distância são o de Pedagogia, com 34,2\% das matrículas; o curso de Administração, com 27,3\% das matrículas e o de Serviço Social, com $8,1 \%$ das matrículas. Esses cursos representam um percentual significativo frente ao crescimento do número de matrículas nos cursos de graduação a distância.

Dessa maneira, a Educação a Distância tem despontado no cenário educacional brasileiro nos últimos anos como um caminho viável para a promoção de ofertas de vagas de Ensino Superior no país. Nos últimos anos, o Brasil vem expandindo o acesso ao Ensino Superior tanto na modalidade presencial quanto a distância, se constituindo numa forma de ensino:

(...) na qual a mediação didático-pedagógica nos processos de ensino e aprendizagem ocorre com a utilização de meios e tecnologias de informação e comunicação, com estudantes e professores desenvolvendo atividades educativas em lugares ou tempos diversos (Decreto ${ }^{\circ} 5622$, de 19/12/2005, Art. $1^{\circ}$ ).

Seguindo a linha de definição do Decreto $n^{\circ}$ 5622, PRETI (1993) destaca o viés não tradicional de aprendizagem, uma vez que para ele a Educação a Distância é definida como:

\footnotetext{
${ }^{6}$ Instituto Nacional de Estudos e Pesquisas Educacionais - Anísio Teixeira.
} 
(...) uma modalidade não tradicional, típica da era industrial e tecnológica, cobrindo distintas formas de ensino-aprendizagem, dispondo de métodos, técnicas e recursos, postos à disposição da sociedade (p. 3).

Em meio ao processo de expansão da Educação a Distância, especificamente aos cursos voltados para o Ensino Superior, percebe-se que essa modalidade de ensino se apresenta como uma oportunidade concreta para que as pessoas que trabalham e que geograficamente não possuem acesso ao Ensino Superior passem a ter a possibilidade de estudar em horários flexíveis, permitindo que conciliassem as atividades de trabalho com os estudos. De fato, a Educação a Distância tem possibilitado a formação de professores, tanto inicial como continuada, em regiões que carecem de qualificação nas diferentes regiões do Brasil.

Na década de 70, a Alemanha, Espanha e a Inglaterra criaram as primeiras universidades públicas que ofereciam cursos a distância, abarcando um grande contingente de alunos trabalhadores. O surgimento da Educação a Distância foi um grande marco para o reconhecimento dessa modalidade no cenário educacional, uma vez que "ao longo da experiência que acumularam, conseguiram obter bom padrão de qualidade nos programas desenvolvidos" (GATTI; BARRETO, p. 87, 2009).

Nesse contexto, o governo brasileiro não vislumbrou a possibilidade de criar uma universidade pública que oferecesse o ensino a distância, entretanto, houve a implementação de alguns programas nacionais de ensino a distância, como o Projeto Minerva ${ }^{7}$ e o Logos, destinado à formação de professores leigos, ambos da década de 70 .

Acompanhando o recente percurso histórico da Educação a Distância no cenário brasileiro, cabe destacar o surgimento da Coordenadoria Nacional de Educação a Distância, que foi criada apenas em 1992 e, logo em seguida, a Secretaria de Educação a Distância, 1995. De acordo com GATTI; BARRETO (2009), mesmo com a criação da referida secretaria, o governo não assumiu de fato uma política para a Educação a Distância, passando apenas a dar apoio a projetos que objetivavam atender algumas demandas no campo educacional

\footnotetext{
${ }^{7}$ Programa de rádio que visava incrementar a formação geral das populações pouco escolarizadas.
} 
brasileiro, como por exemplo, o TELECURSO ${ }^{8}$, o Proformação ${ }^{9}$ e Um Salto para o Futuro ${ }^{10}$.

Segundo GATTI; BARRETO (2009),

Em 1992 o MEC criou a Coordenadoria Nacional de Educação a Distância e, em 1995, a Secretaria de Educação a Distância (Seed). Embora tendo instituído a Seed, o poder público não assume de fato uma política para EAD. Como assinala Preti (2005b), o governo passa apenas a implementar ou apoiar projetos para atender a demandas específicas no campo educacional, como o Telecurso 2000, criado em 1994 com o objetivo de prover formação geral de nível médio, e programas voltados à formação de professores, como o Proformação, dirigido a professores leigos; Um Salto para o Futuro, destinado à formação continuada de professores de $1^{\mathrm{a}}$ a $4^{\mathrm{a}}$ séries e de educação infantil, e alguns cursos de licenciatura (p.89).

A aprovação da Lei de diretrizes e Bases da Educação brasileira (LDB) $n^{\circ}$ 9.394/96 representa muito para a expansão da Educação a Distância no Brasil, pois é a partir dela que a modalidade a distância é legitimada para o Ensino Superior e passa a ganhar força no cenário educacional brasileiro.

Diante desse panorama, a Educação a Distância inicia a construção da sua trajetória no Brasil desde as primeiras décadas do século XX, muito embora, apenas na década de 90, através da Lei de Diretrizes e Bases da Educação (9.394/96), por meio do Artigo 80, tenha sido reconhecida em termos legais:

Art. 80. O Poder Público incentivará o desenvolvimento e a veiculação de programas de ensino a distância, em todos os níveis e modalidades de ensino, e de educação continuada.

$\S 1^{\circ}$ A educação a distância, organizada com abertura e regime especiais, será oferecida por instituições especificamente credenciadas pela União. $\S 2^{\circ}$ A União regulamentará os requisitos para a realização de exames e registro de diplomas relativos a cursos de educação a distância. § $3^{\circ}$ As normas para produção, controle e avaliação de programas de educação a distância e a autorização para sua implementação, caberão aos respectivos sistemas de ensino, podendo haver cooperação e integração entre os diferentes sistemas. $\S 4^{\circ}$ A educação a distância gozará de tratamento diferenciado. (BRASIL, 1996).

Nessa mesma direção, após o surgimento da LDBEN no 9.394/96 a democratização do Ensino Superior ganha força. A carência de professores

\footnotetext{
${ }^{8}$ Programa criado em 1994, com o objetivo de promover a formação geral de ensino médio e a formação de professores.

${ }^{9}$ Programa dirigido a professores leigos.

${ }^{10}$ Programa destinado à formação continuada de professores dos anos iniciais e de educação infantil, e de alguns cursos de licenciatura.
} 
qualificados já era evidente, sendo a LDBEN no 9.394/96 um fator decisivo para que essa qualificação acontecesse, especificamente, através da Educação a Distância.

Ainda sobre os desdobramentos do reconhecimento legal da Educação a Distância como modalidade de ensino, vale destacar que em 2005, por meio do Decreto $\mathrm{n}^{\circ}$ 5.622, foram regulamentados os Artigos 80 e 81 da LDBEN $n^{\circ}$ 9.394/96, que tratam das questões relacionadas ao credenciamento das instituições de ensino, assim como também, das questões relativas ao funcionamento dos cursos de Educação a Distância no Brasil.

O Decreto $\mathrm{n}^{\circ} 5.622$ surge fortalecendo o processo de efetivação e reconhecimento da Educação a Distância, evidenciando a sua relação com o processo de expansão do ensino no Brasil, como podemos perceber na definição do próprio Decreto $\mathrm{n}^{\circ} 5.622$ :

[...] modalidade educacional na qual a mediação didático-pedagógica nos processos de ensino e aprendizagem ocorre com a utilização de meios e tecnologias de informação e comunicação, com estudantes e professores desenvolvendo atividades educativas em lugares ou tempos diversos (BRASIL, 2005).

Vale também destacar que o Decreto apresenta orientações sobre credenciamento, no que se refere a documentos que comprovem a existência de estrutura física e de recursos humanos e tecnológicos necessários para a oferta de cursos na modalidade a distância. Além disso, o Decreto reforça a valorização da formação continuada dos tutores, colocando em evidência esse novo personagem da educação a distância, que passa a assumir as práticas cotidianas nos ambientes virtuais de aprendizagem, especificamente, as práticas voltadas para a relação ensino-aprendizagem.

A partir da breve trajetória histórica apresentada, há evidências de que a Educação a Distância vem se constituindo como um caminho fértil para a universalização do Ensino Superior, uma vez que essa modalidade de ensino possibilita o acesso dos professores das diferentes regiões do Brasil, fomentando assim a execução de políticas públicas.

Dando continuidade ao recorte na trajetória da Educação a Distância no país, cabe destacarmos duas experiências marcantes para a expansão do Ensino Superior no Brasil: O surgimento do Consórcio CEDERJ e a criação da 
Universidade Aberta do Brasil. Sendo assim, segue uma breve apresentação das duas experiências, destacando a relevância de ambas para a história da consolidação do Ensino Superior a distância, da promoção de ofertas de vagas e, consequentemente, da democratização do Ensino Superior no Brasil.

\section{1. \\ O Consórcio CEDERJ/Fundação Cecierj: conhecendo um pouco da sua história}

O consórcio CEDERJ - Centro de Ciências e Educação Superior a Distância do Estado do Rio de Janeiro, foi criado em 1999 através da iniciativa do Governo do Estado do Rio de Janeiro e reúne as universidades públicas do Rio de Janeiro. São elas: Universidade Federal do Rio de Janeiro - UFRJ, Universidade Federal Rural do Rio de Janeiro - UFRRJ, a Universidade Federal Fluminense - UFF, Universidade Estadual do Norte Fluminense Darcy Ribeiro - UENF, Universidade do Estado do Rio de Janeiro - UERJ e Universidade Federal do Estado do Rio de Janeiro - UNIRIO.

A Fundação Cecierj - Centro de Ciências e Educação Superior a Distância do Estado do Rio de Janeiro, também foi criada em 2002, a partir da Lei Estadual $\mathrm{n}^{\mathrm{o}} 103$, de 18/03/2002 ${ }^{11}$, com o objetivo de tornar viável a realização do que se propunha o consórcio CEDERJ, ou seja, promover a educação superior para as populações que não tinham acesso ao ensino superior público.

O CEDERJ surgiu com base na necessidade de atender a população do interior do Estado do Rio de Janeiro que não tinha acesso ao Ensino Superior, devido ao distanciamento geográfico entre os municípios do interior e as universidades públicas do Estado do Rio. Sendo assim, de acordo com as informações apresentadas no portal do CEDERJ, o Consórcio possui 31 polos em todo o Estado do Rio de Janeiro, atendendo a mais de 30 mil alunos matriculados e distribuídos nos seguintes cursos:

- Administração (UFRRJ)

- Administração Pública (UFF)

- Engenharia de Produção (UFF e CEFET)

\footnotetext{
${ }^{11}$ Fonte: site da Fundação Cecierj/CEDERJ - http://CEDERJ.edu.br/CEDERJ/
} 
- Licenciatura em Ciências Biológicas (UENF, UFRJ e UERJ)

- Licenciatura em Física (UFRJ)

- Licenciatura em Geografia (UERJ)

- Licenciatura em História (UNIRIO)

- Licenciatura em Letras (UFF)

- Licenciatura em Matemática (UFF e UNIRIO)

- Licenciatura em Pedagogia (UERJ, UENF e UNIRIO)

- Licenciatura em Química (UENF e UFRJ)

- Licenciatura em Turismo (UFRRJ e UNIRIO)

- Licenciatura em Letras (UFF)

- Tecnologia em Gestão de Turismo (CEFET-RJ)

- Tecnologia em Segurança Pública e Social (UFF)

- Tecnologia em Sistema da Computação (UFF)

O CEDERJ se transformou em autarquia a partir do Parecer CEE $\mathrm{N}^{\circ}$ 035/2011, sendo vinculado à Secretaria de Estado de Ciência e Tecnologia e integrada à Administração Estadual indireta, tendo o Governo do Estado como responsável pelo financiamento e toda a operação do CEDERJ, na época. Essa questão viria a mudar a partir da criação da Universidade Aberta do Brasil, uma vez que a partir do surgimento da UAB houve uma modificação na divisão das responsabilidades administrativas do CEDERJ. FREIRE (2013) destaca essa mudança em seu estudo sobre o Consórcio CEDERJ:

Inicialmente, o Estado era responsável pelo financiamento e toda operação do CEDERJ, e, aos municípios, cabia a tarefa de organização da infraestrutura dos polos. Alguns anos depois, essa configuração sofreu uma importante mudança: com a criação, em de 2005, do Sistema Universidade Aberta do Brasil (UAB), o financiamento do consórcio passou a ser, principalmente, responsabilidade do Governo Federal, via UAB. A partir de então, o Consórcio passou a ser constituído pela colaboração dos três níveis da Federação: o Governo Federal (pela UAB e universidades federais), o Governo Estadual (através da Fundação CECIERJ, que administra o Consórcio CEDERJ e as universidades estaduais) e dos Governos Municipais (com os polos de apoio presencial) (p.21).

Com relação às estruturas administrativas e pedagógicas, o CEDERJ informa através do seu portal que os cursos oferecidos são coordenados por professores do quadro efetivo das universidades públicas do Rio de Janeiro, com o 
auxílio de tutores presenciais e a distância distribuídos no atendimento das disciplinas dos cursos.

No que se refere às atribuições dos tutores, de acordo com as informações listadas no portal do CEDERJ, o tutor presencial atua nos polos do CEDERJ atendendo os alunos em horários fixos, geralmente por duas horas semanais para cada disciplina, promovendo a interação do aluno com os conteúdos da disciplina, priorizando, de acordo com o CEDERJ, uma relação de aprendizagem que favoreça a autonomia dos alunos frente à construção da sua aprendizagem.

Quanto à tutoria a distância, de acordo com as informações apresentadas no portal do CEDERJ, é realizada por meio da plataforma do CEDERJ e por um sistema de Discagem Direta Gratuita (DDG) em horários pré-estabelecidos, divulgados nas salas virtuais da plataforma para que os alunos possam entrar em contato com os tutores nos dias e horários de atendimento dos tutores.

Os tutores e coordenadores são pagos através do sistema de bolsas. A partir do Decreto 5.800/06 e, posteriormente, a Lei $\mathrm{n}^{\circ}$ 11.273/06, autorizando o Fundo Nacional de Desenvolvimento da Educação - FNDE a remunerar a estrutura organizacional do programa com as bolsas de estudos e pesquisa. Em pouco tempo, o FNDE passou essa atribuição para a CAPES - Coordenação de Aperfeiçoamento de Pessoal de Nível Superior, uma vez que a Fundação Cecierj passou a fazer parte do grupo de universidades ligadas ao sistema Universidade Aberta do Brasil.

Com relação ao material didático, segundo as informações apresentadas no portal do CEDERJ, a elaboração é feita por professores chamados de conteudistas, geralmente são docentes indicados pelas universidades que participam do Consórcio. Eles elaboram o conteúdo das aulas, de acordo com os objetivos da disciplina. Após a publicação, que é feita pelo próprio CEDERJ, o material é enviado para os alunos de forma impressa ${ }^{12}$.

Além dos cursos de graduação, o CEDERJ promove cursos de extensão, pré-vestibular social e cursos de atualização para professores. Disponibiliza também um programa de ensino voltado para jovens e adultos, o CEJAS - Centros de Educação de Jovens e Adultos, que atende o segundo segmento do Ensino

\footnotetext{
12 Os materiais das disciplinas também são disponibilizados em pdf nas salas virtuais das disciplinas.
} 
Fundamental ( $6^{\circ}$ ao $9^{\circ}$ ano), voltado para jovens a partir de 15 anos de idade e que já concluíram o primeiro segmento do Ensino Fundamental.

Retomando a questão da oferta de cursos de graduação pelo CEDERJ, vale ressaltar que atualmente acontece através do surgimento do Consórcio entre o Sistema Universidade Aberta do Brasil (UAB)/Coordenação de Aperfeiçoamento de Pessoal de Nível Superior (CAPES), passando a partilhar as responsabilidades financeiras, logísticas e acadêmicas com o Consórcio CEDERJ. Segundo SANTOS (2015):

\begin{abstract}
No âmbito político, o modelo consorciado CEDERJ/UAB/Capes se caracteriza pela junção de diferentes responsabilidades por parte das instituições envolvidas no consórcio: ao Governo estadual, através da Fundação CECIERJ e da SECT, cabe a gestão administrativa, logística e acadêmica do modelo pedagógico proposto; o Governo Federal responde, fundamentalmente, pelo pagamento de bolsas e pela regulação dos cursos; as universidades consorciadas são responsáveis pelo projeto político-pedagógico e pela gestão acadêmica dos cursos, junto ao consórcio CEDERJ; e as prefeituras fluminenses, em conjunto com o CEDERJ, são responsáveis pela instalação e manutenção dos polos de apoio presencial localizados nos municípios (p. 15).
\end{abstract}

Dessa maneira, surge o modelo consorciado CEDERJ/UAB/Capes que passa a dividir as responsabilidades e necessidades organizacionais e estruturais em parceria com as universidades públicas brasileiras.

\title{
2.2.
}

\section{A Universidade Aberta do Brasil: um breve relato}

A Universidade Aberta do Brasil (UAB) foi instituída pelo Decreto $\mathrm{n}^{\circ}$ 5.800, de 8 de junho de 2006, buscando reunir as diversas universidades públicas $^{13}$ do país, com o objetivo de implementar um sistema nacional dessa

\footnotetext{
${ }^{13}$ Lista das universidades que participam do programa UAB: Região Centro-Oeste, Distrito Federal: UnB; Goiás: UFG; UEG; Mato Grosso: UFMT; IFMT; Unemat. Mato Grosso do Sul: UFMS; UEMS; Região Nordeste: Alagoas: UFAL; IFAL; Uncisal; UNEAL; Bahia: UFBA; IFBA; UEFS; UESB; UESB; UNEB; Ceará: UFC; IFCE; UECE; Maranhão: UFMA; UEMA; IFMA; Paraíba: UFPB; IFPB; IFPB; Pernambuco: UFPE; Univasf; UFRPE; IFPE; UPE; Piauí: UFPI; UESPI; Rio Grande do Norte: UFRN; Ufersa; IFRN; UERN; Sergipe: UFS; Região Norte: Amazonas: UFAM; IFAM; UEA; Pará: UFPA; IFPA; UEPA; Rondônia: UNIR; Roraima: UFRR. Tocantins: UFT; UNITINS; Região Sudeste Espírito Santo: UFES; IFES; Minas Gerais: UFMG; UFV; UFJF; UFLA; UFOP; UFSJ; UFU; UFVJM; Unifal; Unifei; IFTM; UEMG; Unimontes; Rio de Janeiro: CEDERJ (UENF, UERJ, UFF, UFRJ, UNIRIO); UFRRJ; Cefet-RJ; FIOCRUZ; São Paulo: Unifesp; UFSCar; UFABC; Unesp; Região Sul: Paraná: UFPR; UTFPR; UEM; UEPG;
} 
modalidade, ampliando a oferta de vagas no país. A UAB surgiu com o objetivo de promover a formação e capacitação inicial e continuada de professores que trabalham na Educação Básica, conforme é ressaltado no Decreto no 2429 que regulamenta o sistema da $\mathrm{UAB}$ :

É sua prioridade "a formação e capacitação inicial e continuada de professores para a educação básica, com a utilização de metodologias de educação a distância, convocando as instituições de educação superior públicas para a oferta de cursos superiores a distância" (Brasil, 2006).

Além de ter como prioridade a formação e capacitação inicial e continuada de professores, o sistema UAB tem como objetivo ampliar a oferta de matrículas no Ensino Superior para formar professores leigos que já atuam na Educação Básica.

Segundo CASTRO, 2013:

De um lado a necessidade de expandir o acesso ao ensino superior, de outro a necessidade de formar os professores leigos já em serviço e formar mais professores para atender a demanda da educação básica já universalizada em um país de proporções continentais como o Brasil (p.17).

Para tanto, busca-se articular as universidades já existentes, promovendo o Ensino Superior público frente às regiões distantes dos centros urbanos e, consequentemente, das universidades públicas (BRASIL, 2006). Assim, iniciou-se um processo de adesão à UAB de alguns consórcios existentes, inclusive o Consórcio CEDERJ:

\begin{abstract}
A partir desse momento, alguns consórcios já instituídos aderiram à UAB e esse foi o caso do Consórcio CEDERJ. A adesão se deu em resposta ao edital lançado pela UAB que previa o financiamento para cursos superiores públicos na modalidade a distância. O documento priorizava que esse aporte financeiro se desse principalmente aos consórcios, haja vista que os principais critérios de escolha das instituições eram o maior número de vagas que elas pudessem oferecer e a maior abrangência geográfica (FREIRE, 2013, p. 26).
\end{abstract}

A partir desse aporte financeiro para cursos públicos superiores na modalidade a distância, várias iniciativas para o oferecimento de $\mathrm{EaD}$ foram 
surgindo em todo o país, evidenciando o aumento do número de matrículas nas IES (FREIRE, 2013).

Nessa mesma direção o número de matrículas do sistema UAB aumentou significativamente, como podemos verificar no gráfico abaixo, considerando o período de 2007 a 2013:

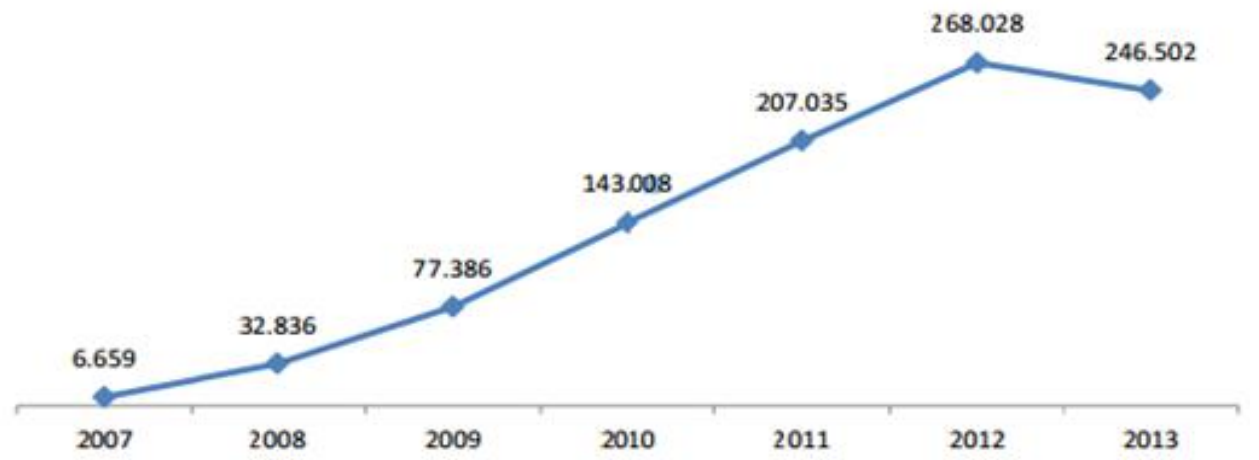

Gráfico 1: Matrículas no Sistema UAB 2007-2013. Fonte: http://portal.mec.gov.br/

Sobre a organização estrutural, segundo informações do portal da UAB, o sistema se organiza a partir dos polos de apoio presencial, que são espaços físicos disponibilizados e mantidos por municípios ou governos de estado que assumem o compromisso de garantir a infraestrutura física e pedagógica para os cursos, ou seja, laboratórios de informática, bibliotecas entre outros.

A UAB tem como base de seu funcionamento a articulação entre as instituições de ensino superior e os governos estaduais e municipais, buscando atender às demandas locais por Educação Superior, por meio das instituições de ensino responsáveis por ministrar os cursos oferecidos em determinados municípios ou microrregião através dos polos de apoio presencial instalados nos prédios das universidades que fazem parceria com o sistema.

Com relação à organização da gestão pedagógica dos cursos, de acordo com as informações apresentadas no portal da $\mathrm{UAB}$, a figura do Coordenador assume a função de articular o sistema UAB às universidades que participam do programa, dando apoio aos coordenadores dos cursos e aos polos presenciais. De acordo com as informações listadas no portal da UAB, a partir da realização da articulação entre as instituições públicas de ensino e os polos de apoio presencial, a UAB, juntamente com a CAPES passa a assegurar o fomento, no sentido de garantir o bom funcionamento dos cursos. 
A figura 1 ilustra a organização do funcionamento:

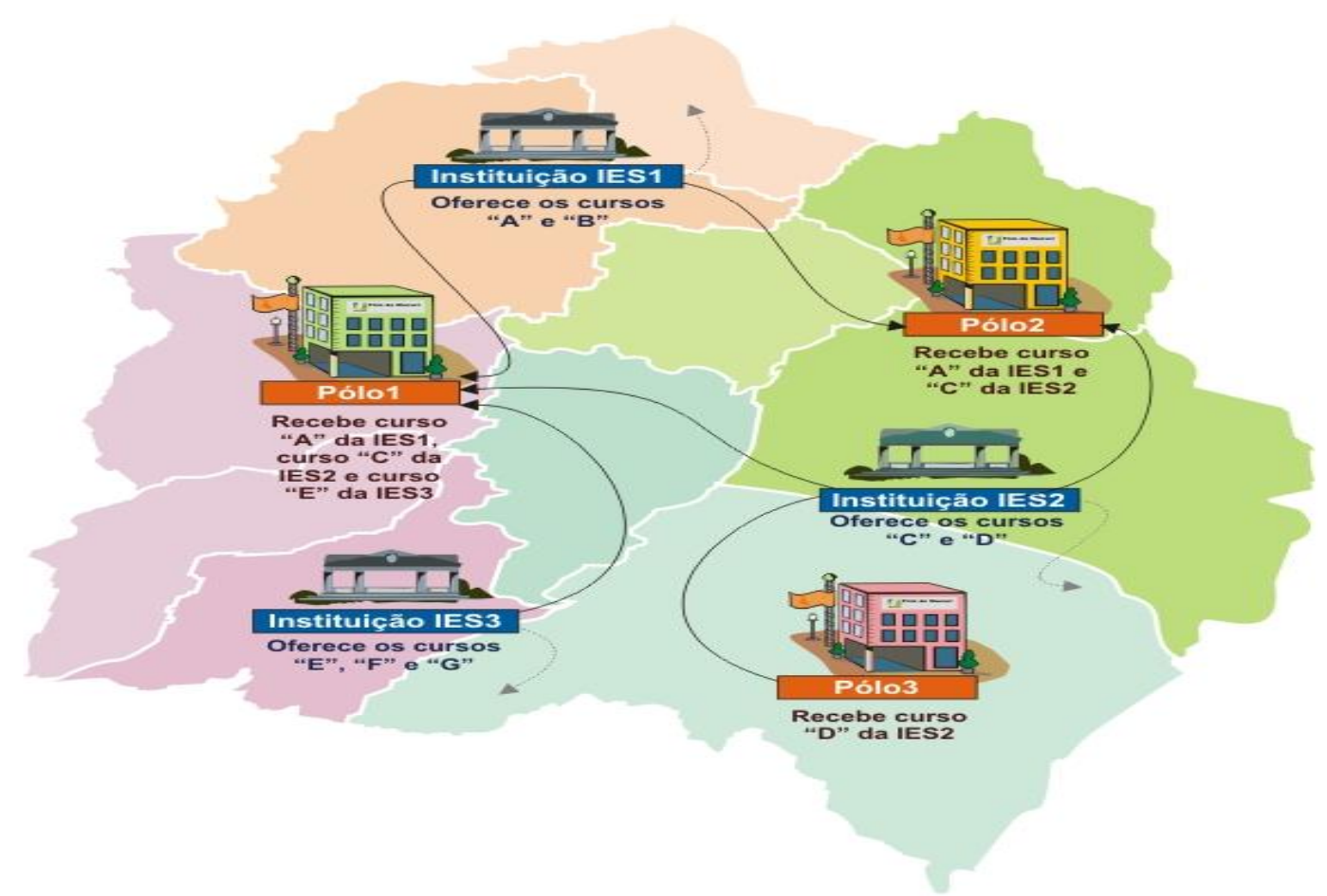

Figura 1: Constituição do funcionamento do sistema UAB - disponível no sítio eletrônico da UAB (http://uab.capes.gov.br/index.php/sobre-a-uab/teste).

Com relação ao trabalho de tutoria, os tutores são divididos entre os presenciais e a distância. Os tutores precisam ter experiência no magistério ou formação em cursos de pós-graduação. Assim como no CEDERJ, devem buscar promover a interação do aluno com os conteúdos da disciplina priorizando uma relação de aprendizagem que favoreça a autonomia dos alunos frente aos temas e conteúdos discutidos.

Além desses atores, de acordo com as informações listadas no portal da $\mathrm{UAB}$, os cursos contam com o professor formador, que é responsável por ministrar aulas nos polos presenciais. Ao mesmo tempo, existe também a função de professor conteudista, responsável pela produção do material didático, desenvolvimento de projetos e de pesquisas que se relacionem aos cursos da UAB.

Sobre o pagamento das bolsas dos tutores e coordenadores dos cursos, a UAB segue a resolução CD/FNDE $n^{\circ} .44$ de 29 de dezembro de 2006 que estabelece as diretrizes para a liberação de bolsas de estudo e de pesquisa aos 
profissionais ligados aos cursos do Sistema Universidade Aberta do Brasil, liberadas pela CAPES.

Com relação a CAPES, vale ressaltar que esta teve papel crucial frente ao aumento do processo de expansão da Educação a Distância, sendo fundamental para a articulação entre as políticas da Educação Básica e Superior.

Nessa mesma direção, GATTI; BARRETO (2009) ressaltam que:

Diante do aumento da complexidade dos processos de expansão da educação e, em particular, da modalidade EAD, o Ministério da Educação amplia e fortalece o papel da Capes a partir de 2007, instituindo ações voltadas à formação de professores para o ensino básico, em busca de uma articulação mais orgânica entre as políticas da educação básica e superior (p. 100).

Esse aumento significativo na oferta de cursos a partir do sistema UAB/Capes vem ganhando força no cenário educacional, alcançando números bem expressivos nos últimos anos, conforma destaca SANTOS (2015):

Feito em parceria com as universidades públicas brasileiras, o Sistema UAB/Capes registrava, em 2011, a oferta de 930 cursos de formação inicial em nível superior, sendo 697, ou seja, 74,9\%, de formação de professores e os demais cursos se destinavam à formação de gestores e pessoal administrativo. Neste mesmo ano, a região Sudeste representava a segunda região com maior oferta de cursos em $\mathrm{EaD}$ - o Nordeste era a primeira -, apresentando 155 cursos, ou seja, 22,2\% do total de cursos. Nesta região, o Estado do Rio de Janeiro apresentava 24 cursos, representando $15,5 \%$ do total de cursos oferecidos na região e 3,4\% do Brasil. (GATTI et al., 2011) (p. 18).

Diante do exposto, cabe ressaltar que a UAB vem se constituindo como um espaço relevante frente ao processo de expansão da educação, tornando-se um importante instrumento para as políticas atuais de formação docente no país, tendo um papel de articulador entre as instituições de Ensino Superior que fazem parte do sistema $\mathrm{UAB}$, no sentido de atender as demandas locais das regiões onde as universidades estão inseridas. $\mathrm{O}$ sistema UAB garante $\mathrm{o}$ fomento $^{14}$ às universidades cadastradas no programa, assegurando o funcionamento dos cursos.

\footnotetext{
${ }^{14}$ Recursos financeiros concedidos para a manutenção dos cursos, no que se refere à produção e distribuição de materiais didáticos, à aquisição de laboratórios pedagógicos, toda a infraestrutura dos cursos e, também à capacitação dos profissionais envolvidos.
} 


\section{3 Tutor, professor ou suporte virtual $?^{15}$ Uma análise
conceitual da identidade do tutor}

A identidade humana não é dada, no acto do nascimento. Constróise na infância e deve re-construir-se sempre ao longo da vida (DUBAR 1997: 13).

As questões que envolvem a identidade docente vêm sendo alvo de vários estudos nos últimos anos no campo da Educação. Entretanto, quando o tema se volta para a identidade do tutor em cursos a distância, percebe-se que ainda precisamos caminhar em direção de estudos que coloquem em evidência a necessidade de uma compreensão clara sobre o seu trabalho em ambientes virtuais, no que se refere à construção da sua identidade profissional, uma vez que "a identidade do tutor, professor e/ou mediador que atua na educação a distância não é um dado em consenso, a começar pela nomenclatura de sua função e posteriormente suas atribuições" (CASTRO, 2013, p. 47).

Para refletir sobre a identidade do tutor, destacaremos inicialmente as contribuições de Dubar (1997). Para ele, a questão da identidade se vincula ao viés social, sendo o processo de identidade social reconstruído permanentemente a partir do processo de socialização.

Nesse contexto, a identidade nunca é um fato dado, mas construído e reconstruído através do processo de socialização, onde a incerteza e a precariedade assumem um papel crucial frente a esse processo, pois é por meio delas que a reconstrução da identidade acontece.

Dessa maneira, percebe-se que a construção da identidade profissional passa pelo processo de socialização, de modo que se constrói por intermédio das relações estabelecidas entre os sujeitos ao longo da vida. Esse processo de socialização pressupõe uma construção identitária singular do indivíduo, assim

\footnotetext{
${ }^{15} \mathrm{O}$ termo suporte virtual é entendido neste estudo como uma função desvinculada do fazer pedagógico, na qual o tutor é concebido apenas como um garantidor do cumprimento das questões burocráticas dos cursos no formato $\mathrm{EaD}$.
} 
como também uma identidade mais plural, imersa em um determinado grupo social, na qual o indivíduo se socializa e faz parte.

Nesse contexto, a identidade social se constitui num:

(...) resultado por vezes estável e provisório, individual e colectivo, subjectivo e objectivo, biográfico e estrutural, de diversos processos de socialização que, conjuntamente constroem os indivíduos e definem as instituições (DUBAR 2000, p. 109).

Em consonância com os processos de socialização mencionado por DUBAR (2000), TARDIF; RAYMOND (2000) definem "socialização como um processo de formação do indivíduo que se estende por toda a história de vida e comporta rupturas e continuidades" (p.217).

DUBAR (2000) e TARDIF; RAYMOND (2000) convergem na visão de que a socialização pressupõe uma construção identitária, que se dá por meio da interação com os outros, em determinados grupos sociais, inclusive em grupos de trabalhadores.

$\mathrm{Na}$ concepção de TARDIF; RAYMOND (2000), quem modifica o trabalhador é o trabalho, numa relação contínua em que ambos acabam transformando um ao outro e, consequentemente interferindo na construção da identidade do trabalhador, "pois a sua identidade carrega as marcas de sua própria atividade, e uma boa parte de sua existência é caracterizada por sua atuação profissional" (TARDIF; RAYMOND, 2000, p. 210)".

Para MIL; FIDALGO (2007), a identidade do tutor passa pelo conceito de Polidocência, ou seja, por uma visão que envolve o trabalho coletivo na Educação a Distância, se constituindo num "conjunto articulado de trabalhadores, necessário para a realização das atividades de ensino-aprendizagem na educação a distância, denominamos de Polidocência” (p. 6).

O conceito de Polidocência definido por MILL; FIDALGO (2007) também sugere a presença da socialização em sua composição conceitual, pois é partir da articulação entre os trabalhadores na EAD que a Polidocência se constrói. Essa articulação acontece por meio das práticas coletivas travadas mediante a socialização entre todos os envolvidos no processo de ensinoaprendizagem a distância. 
SANTOS; WINCHUAR (2014) corroboram com a definição de Polidocência, destacando o caráter coletivo da identidade dos sujeitos, enfatizando que não pode ser pensada de forma isolada, pois se complementa na relação com o outro, evidenciando a presença da socialização nesse processo:

Nessa direção, percebe-se que não existe a possibilidade de pensar esses sujeitos de forma isolada, pois, se complementam no outro, no processo de ensino e aprendizagem a distância e fazem parte de um grupo. Mesmo ocupando posições diferenciadas, possuem um perfil aproximado (p. 15).

Nesse contexto, percebe-se que a questão da socialização possui um papel de destaque na construção identitária, uma vez que "a identidade dos sujeitos está ligada à sua existência no meio social e ao papel que desempenha na organização e no funcionamento da sociedade" (SANTOS et. al., 2014, p.3).

Considerando a construção da identidade profissional do tutor, vale destacar que em meio às relações estabelecidas entre os tutores e as diferentes instituições de ensino onde atuam, certamente, o aspecto estrutural e os processos de socialização que ocorrem nesses diferentes espaços acabam por interferir na construção da identidade do tutor, resultando em definições construídas a partir das representações que as instituições constroem sobre as práticas realizadas pelos tutores, definindo o olhar que as instituições vão formar acerca desse personagem, assim como também sobre as representações dos tutores sobre a própria identidade.

Alguns estudos apontam para questões relacionadas à identidade do tutor e evidenciam que essa temática precisa ser analisada com mais ênfase, uma vez que a função do tutor vem se tornando fundamental para o pleno desenvolvimento das práticas educativas na Educação a Distância. Os trabalhos de SANTOS; WINCHUAR, (2014), SANTOS et. al. (2014), NUNES (2013), CAMPOS; AMARAL (2011), NEVES; FIDALGO (2008), OLIVEIRA (2008), VILLARDI (2005), MILL; FIDALGO (2007), GONZALES (2005), MACHADO; MACHADO (2004), entre outros, sinalizam a necessidade de uma ampliação nos estudos e pesquisas sobre a identidade do tutor, que é permeada por contradições que interferem diretamente na qualidade dos cursos a distância no Brasil.

O levantamento de pesquisas e trabalhos sobre o tema apontou que os estudos sobre a identidade dos tutores nos últimos anos buscaram identificar as especificidades desta função, de modo a conhecer a sua importância frente ao 
desempenho dos alunos e à permanência nos cursos, assim como trouxe à discussão a relação da tutoria diante da garantia da qualidade dos processos de aprendizagem. Esses apontamentos reforçaram a intenção de pesquisar a temática, tal como a sua necessidade é apontada por VILLARDI (2005):

\begin{abstract}
A questão da tutoria é, nesse momento, uma das mais relevantes a ser estudada e abordada, uma vez que a observação de alguns processos de formação, via $\mathrm{EaD}$, vem apontando a atuação do tutor como decisiva para o sucesso da iniciativa e permanência do aluno até o final do curso (p. 440).
\end{abstract}

Segundo CASTRO (2013):

O mediador pedagógico, quando concebido como tutor, também enfrenta problemas quanto à sua identidade. "Pois não tem um reconhecimento profissional, social, econômico e empregatício compatível com suas atribuições, embora seja o responsável direto, na maioria dos sistemas constituídos na EAD, pelo atendimento mais próximo aos alunos" (Alonso, 2010:1330). A cada ano se intensifica o debate pela regulamentação das atividades em tutoria na educação a distância, como pode ser notado no recente movimento pelo Projeto de Lei 2435/2011 que prevê a regularização dessa atividade profissional (p.13).

Em meio aos temas vinculados às pesquisas no campo da Educação a Distância, a atuação diversificada do tutor tem se destacado, pois assume atribuições distintas nos cursos. Entretanto, mesmo diante da inexistência de um modelo único de atuação, tais atribuições convergem no objetivo de mediar o conhecimento, sendo um elo significativo para o andamento do processo de aprendizagem dos alunos.

Sobre a diversidade de papéis do tutor PRETI (2003) destaca que:

(...) o tutor é uma pessoa que assume diversos papéis e cujo objetivo principal é o acompanhamento do estudante em seus esforços de aprender. Segundo Deslise et al. (1985), tendo conhecimento de base do conteúdo, ele é um facilitador que ajuda o estudante a compreender os objetivos do curso, um observador que reflete, um conselheiro sobre os métodos de estudo, um psicólogo que é capaz de compreender as questões e as dificuldades do aprendiz e de ajudálo a responder de maneira adequada e, finalmente, um especialista em avaliação formativa (p.6).

Dessa maneira, um aprofundamento sobre os múltiplos modelos de atuação do tutor se configura como uma necessidade.

No que se refere ao aspecto legal da atuação do tutor, há uma predominância nas pesquisas sobre as leis e as condições do trabalho docente, mas não 
especificamente do tutor, pois o mesmo raramente é associado à função docente, o que levanta questionamentos sobre o distanciamento das funções de tutoria e docência.

De acordo com NEVES; FIDALGO (2008):

A inexistência de ordenamentos jurídicos claros que regulam a atividade do docente virtual remete a se pensar em que medida as questões relativas aos direitos e deveres desse profissional podem se consolidar. Pois, na legislação não há alusão sobre a regulamentação da profissão tutor, portanto, não há garantias no que se refere ao processo de profissionalização desses também docentes (p. 6).

Considerando esse contexto, a atuação do tutor surge como algo a ser investigado com mais propriedade, tendo em vista que os estudos trazem à discussão múltiplas questões ligadas ao trabalho de tutoria e que corroboram para que a identidade do tutor permaneça indefinida, dificultando a legitimidade dos limites de sua atuação.

A função desempenhada pelo tutor no cenário da Educação a Distância ainda é recente e a delimitação das suas funções não é clara e definida, reforçando a criação de outros termos para designar a função, como por exemplo, mediador pedagógico e professor-tutor. $\mathrm{O}$ que se percebe é que o conceito tutor acaba ultrapassando os limites impostos ao significado do seu termo, assim como destaca GONZALES, 2005:

No cenário da educação a distância, o papel do tutor extrapola os limites conceituais, imposto na sua nomenclatura, já que ele, em sua missão precípua, é educador como os demais envolvidos no processo de gestão, acompanhamento e avaliação dos programas. (p. 1).

Partindo da visão de GONZALES (2005), identificamos que o termo tutor extrapola os limites conceituais do seu próprio termo, certamente acabando por promover diferentes definições e formas de tutoria, não existindo apenas um modelo único de tutoria. Essa questão dos diferentes modelos de tutoria também é retratada por SANTOS et. al (2014):

Não existe um modelo único de tutoria, nem um comportamento padrão indicado para o tutor, ou seja, ele vai sendo construído ao longo de sua experiência e ao criar um formato institucional em EaD, determinando as alterações que melhor atendam as suas necessidades dentro de sua estrutura administrativa, pedagógica, tecnológica e comunicacional. Mas independente do modelo que a instituição usar, 
a tutoria, sem dúvida alguma, é a forma mais eficaz de mediação e interação em um curso a distância (p. 2).

Autores como CAMPOS; AMARAL (2011) apresentam definições para o termo tutor, a partir de diferentes nomenclaturas e expressões. A diferenciação dos termos é determinada pela perspectiva teórico-filosófica de cada curso. Nesse sentido, Para CAMPOS; AMARAL (2011):

A expressão Mediação Pedagógica é aqui utilizada, preferencialmente à tradicional denominação Tutoria para sublinhar a complexidade da atuação do Mediador Pedagógico - o tutor - em cursos na modalidade a distância - EAD -, em uma perspectiva sócio-interacionista (p. 50).

CAMPOS; AMARAL (2011) abordam a complexidade da atividade de tutoria, ressaltando que o termo não permite receber toda a complexidade que envolvem as atividades desenvolvidas na tutoria:

\begin{abstract}
A tutoria ou, como preferimos, a mediação pedagógica a distância é, uma atividade essencialmente individualizada e permanente no processo de desenvolvimento de um curso na modalidade a distância. Acompanhar e oferecer ao aluno todo o auxílio necessário ao processo de aprendizagem, incentivando-o a realizar as tarefas propostas é o seu objetivo. Ela deve contribuir para o estabelecimento de relações entre os conhecimentos adquiridos e as situações concretas, facilitando a solução das dificuldades encontradas. Estamos nos referindo a uma atividade de tutoria bem mais complexa do que o termo tutoria permite perceber (p. 51).
\end{abstract}

Para SANTOS; WINCHUAR, (2014) o tutor deve ser compreendido como um agente motivador, que deve permanecer em constante busca de inovação em meio aos ambientes de aprendizagem colaborativa, atendendo as necessidades dos alunos:

O tutor procura a inovação, a todo o momento, a partir de ambientes de aprendizagem colaborativos, estando atento e em constante contato com os alunos, para o atendimento de suas necessidades. Ele é um agente motivador, contribuindo para que o aluno alcance seus objetivos e construa sua autonomia (p. 4).

A definição de OLIVEIRA (2008) sobre o termo tutor destaca o caráter motivador das ações didáticas dentro do viés administrativo-pedagógico, em que o tutor assume um papel de cunho motivador, em meio ao universo de ações administrativo-pedagógicas que permeiam o processo de aprendizagem dos alunos. Para ele: 
(...) esta figura quem lida diretamente com o estudante, seja para prestar esclarecimentos administrativos, seja no processo de ensino e aprendizagem, na avaliação do processo formativo do estudante ou, simplesmente, na monitoria das atividades dos estudantes. Por isso, é considerado o 'fator humanizador' do sistema de educação na modalidade a distância (OLIVEIRA, 2008, p. 30)

De acordo com MACHADO; MACHADO (2004), os aspectos que definem o termo tutor giram em torno da questão do domínio dos assuntos relacionados à matéria que o tutor trabalha e de habilidades voltadas para as questões relacionadas ao planejamento, avaliação, atributos psicológicos e éticos. Segundo as autoras, o tutor:

(...) deve conhecer com profundidade os assuntos relacionados com a matéria e área profissional em foco. A habilidade para planejar, acompanhar e avaliar atividades, bem como motivar o aluno para o estudo, também são relevantes. Na formação pessoal, deve ser capaz de lidar com o heterogêneo quadro de alunos e ser possuidor de atributos psicológicos e éticos: maturidade emocional, empatia com os alunos, habilidade de mediar questões, liderança, cordialidade e, especialmente a capacidade de ouvir (p.7).

Em consonância aos aspectos definidos por MACHADO; MACHADO (2004) sobre o tutor, NUNES (2013) em seu trabalho de análise de conteúdo sobre os itens identificados como atribuições dos tutores, reforça o viés pedagógico da função, destacando a necessidade do tutor ser compreendido como um sujeito ligado diretamente ao trabalho pedagógico.

O tutor deve ser compreendido como um dos sujeitos que participa ativamente da prática pedagógica. Suas atividades desenvolvidas a distância e/ou presencialmente devem contribuir para o desenvolvimento dos processos de ensino e de aprendizagem e para o acompanhamento e avaliação do projeto pedagógico (p.2-3).

Os Referenciais de Qualidade para a Educação Superior a Distância (BRASIL, 2007) consideram o trabalho de tutoria como algo fundamental para o processo de aprendizagem, uma vez que o tutor desempenha um papel ativo dentro das atividades pedagógicas desenvolvidas nos cursos na modalidade a distância, onde precisa ser percebido "como um dos sujeitos que participa ativamente da prática pedagógica. Suas atividades desenvolvidas a distância e/ou presencialmente devem contribuir para o desenvolvimento dos processos de ensino e de aprendizagem". (BRASIL, 2007, p. 21). 


\section{1.}

\section{Tutoria presencial e a distância: especificidades da função do tutor}

A questão da identidade profissional do tutor se configura como uma lacuna no universo da Educação a Distância, uma vez que "o tutor ainda é um profissional que carece de perfil profissiográfico que lhe confira uma formação definida e um espaço determinado na modalidade" HACKMAYER; BOHADANA (2014, p.1). Assim, o delineamento do seu perfil se faz cada vez mais necessário.

A expansão de cursos a distância acarretou o crescimento significativo de profissionais exercendo a função de tutor, promovendo também a ampliação de estudos acerca da sua identidade profissional, como por exemplo, os de HACKMAYER; BOHADANA (2014), ALONSO (2010), MENDES (2013) e MILL; FIDALGO (2015). Ao refletirmos sobre o trabalho de tutoria, torna-se necessário buscarmos identificar as principais características destes atores.

Para ALONSO (2010):

É salutar, portanto, no cenário da $\mathrm{EaD}$, que se efetivem, definitivamente, os novos campos profissionais que surgem com o seu uso, sem que se confunda a quem cabe o papel de mediar aprendizagem/conhecimento e de tomar decisões pedagógicas afetas ao processo da formação (p. 12).

Considerando que o conceito de tutoria surge em meio a uma multiplicidade de papéis, é importante salientar que a sua prática se estabelece virtualmente e presencialmente, partindo de objetivos comuns: a mediação da aprendizagem, sendo essa a sua principal característica.

Entre as denominações atribuídas a este docente, estão: tutor virtual, tutor eletrônico, tutor presencial, tutor de sala de aula, tutor local, orientador acadêmico, animador e diversas outras. O que caracteriza este trabalhador é sua função de acompanhar os alunos no processo de aprendizagem, que se dá, na verdade, pela intensa mediação tecnológica (MILL; FIDALGO, 2015, p. 1).

Além das diferentes denominações apresentadas por MILL; FIDALGO (2015), vemos a partir dos estudos de MENDES (2013) que o tutor assume múltiplos papéis em diferentes espaços: 
Há o tutor que é responsável por uma disciplina em um ou dois polos. Há o tutor que é responsável por uma disciplina, mas atende vários polos ao mesmo tempo. Há o tutor que não tem uma disciplina específica e é responsável por um polo, ou seja, atende todas as disciplinas que são ofertadas. Há o tutor que atua em um polo diferente em cada semestre (p. 13).

Os Referencias de Qualidade para a Educação Superior a Distância (2007) orientam a elaboração e implementação dos cursos a distância. Dentro desse processo, os referenciais também destacam apontamentos sobre as formas de interação entre tutor, professor e alunos.

Dessa maneira, os Referenciais de Qualidade para a Educação Superior a Distância citam as principais atribuições dos tutores presenciais e a distância (BRASIL, 2007) como:

\begin{abstract}
A tutoria presencial atende os estudantes nos pólos, em horários pré-estabelecidos. Este profissional deve conhecer o projeto pedagógico do curso, o material didático e o conteúdo específico dos conteúdos sob sua responsabilidade, a fim de auxiliar os estudantes no desenvolvimento de suas atividades individuais e em grupo, fomentando o hábito da pesquisa esclarecendo dúvidas em relação a conteúdos específicos, bem como ao uso das tecnologias disponíveis. Participa de momentos presenciais obrigatórios, tais como avaliações, aulas práticas em laboratórios e estágios supervisionados, quando se aplicam. O tutor presencial deve manter-se em permanente comunicação tanto com os estudantes quanto com a equipe pedagógica do curso.
\end{abstract}

A tutoria a distância atua a partir da instituição, mediando o processo pedagógico junto a estudantes geograficamente distantes, e referenciados aos pólos descentralizados de apoio presencial. Sua principal atribuição deste profissional é o esclarecimento de dúvidas através fóruns de discussão pela Internet, pelo telefone, participação em videoconferências, entre outros, de acordo com o projeto pedagógico. O tutor a distância tem também a responsabilidade de promover espaços de construção coletiva de conhecimento, selecionar material de apoio e sustentação teórica aos conteúdos e, frequentemente, faz parte de suas atribuições participar dos processos avaliativos de ensino-aprendizagem, junto com os docentes (p.21)

Nesse sentido, as ações do tutor se dividem em dois papéis: a tutoria presencial e a tutoria a distância em consonância com os Referenciais de Qualidade para a Educação Superior a Distância (BRASIL, 2007) que apontam para a intercambialidade das funções frente a "um modelo de educação a distância que privilegie forte mobilidade espacial de seu corpo de tutores" (BRASIL, 2007, p. 22). 
Sobre o trabalho desenvolvido pelos tutores, MENDES (2013) destaca aspectos convergentes entre as funções e, ao mesmo tempo, demarca especificidades inerentes aos dois tipos de atuação:

A tutoria presencial atende os estudantes nos polos presenciais. O tutor deve conhecer o projeto do curso e o material didático, a fim de auxiliar os estudantes em suas atividades individuais e em grupo, fomentando a pesquisa e esclarecendo dúvidas específicas e sobre as tecnologias usadas. Deve participar dos momentos presenciais, como avaliações e aulas práticas, e se manter em comunicação com os alunos e com a equipe do curso.

A tutoria a distância atua a partir da instituição, mediando o processo pedagógico junto a estudantes geograficamente distantes. Deve esclarecer dúvidas por meio de recursos tecnológicos, promover espaços de construção coletiva de conhecimento e participar dos processos avaliativos (p. 13).

Para ilustrar as principais características das atividades desenvolvidas pelos tutores presenciais e a distância, elencamos em um quadro das principais formas de interação dos tutores com os alunos, baseado na discussão estabelecida sobre a subdivisão do trabalho de tutoria a partir do espaço e tempo de trabalho.

\begin{tabular}{|c|c|c|}
\hline \multicolumn{3}{|c|}{ Quadro das principais características das atividades dos tutores } \\
\hline Tutores & $\begin{array}{l}\text { Formas de interação em } \\
\text { relação ao tempo e espaço }\end{array}$ & Principais atividades desenvolvidas \\
\hline Presenciais & $\begin{array}{l}\text { Síncrona; } \\
\text { Atendimento aos } \\
\text { estudantes nos polos } \\
\text { presenciais em horários pré- } \\
\text { estabelecidos. }\end{array}$ & $\begin{array}{l}\text { - Auxiliar os alunos em suas atividades } \\
\text { individuais e em grupo; } \\
\text { - Incentivar a pesquisa e esclarecer as dúvidas } \\
\text { específicas e sobre as tecnologias utilizadas; } \\
\text { - Participar dos momentos presenciais, } \\
\text { avaliações e aulas práticas. }\end{array}$ \\
\hline A distância & \begin{tabular}{ll}
\multicolumn{3}{l|}{ Síncrona e assíncrona; } \\
Mediação do processo \\
pedagógico junto a \\
estudantes & geograficamente \\
distantes. &
\end{tabular} & $\begin{array}{l}\text { - Esclarecer dúvidas dos alunos por meio de } \\
\text { recursos tecnológicos; } \\
\text { - Ampliar e promover espaços de construção } \\
\text { coletiva de conhecimento; } \\
\text { - Participar dos processos avaliativos. }\end{array}$ \\
\hline
\end{tabular}

Quadro 01 - características das atividades dos tutores. Elaboração própria, tendo como fonte: Referenciais de Qualidade para a Educação Superior a Distância (2007), HACKMAYER e BOHADANA (2014), ALONSO (2010), MENDES (2013) e MILL e FIDALGO (2015). 
As ações do tutor partilham do mesmo objetivo de promover a construção de conhecimentos dos alunos através da interação-mediação com eles. Neste caso, não se trata de subdividir o trabalho para defender o lado mais importante nas ações desenvolvidas pelos tutores, mas sim a necessidade de reconhecer a relevância do tutor dentro desse processo de interação/mediação com os alunos frente à construção de conhecimentos, "sendo este entendido como um dos principais agentes da mediação pedagógica na modalidade a distância" (CASTRO, 2013, p. 23).

Nesse contexto, os Referenciais de Qualidade para a Educação Superior a Distância (BRASIL, 2007) considera que:

O tutor deve ser compreendido como um dos sujeitos que participa ativamente da prática pedagógica. Suas atividades desenvolvidas a distância e/ou presencialmente devem contribuir para o desenvolvimento dos processos de ensino e de aprendizagem. (BRASIL, 2007, p. 21)

A função do tutor se constitui, portanto, em um elo fundamental entre o distanciamento físico do aluno e a universidade. Desse modo, possui um papel de mediação frente à construção de conhecimento, reduzindo as barreiras físicas que dificultam o acesso de boa parte dos alunos, uma vez que "o tutor atua mediando o processo pedagógico junto a estudantes geograficamente distantes" (Referenciais de Qualidade para a Educação Superior a Distância, BRASIL, 2007, p. 21)

\section{2.}

\section{Competências necessárias para o exercício da função do tutor}

A discussão sobre as atividades do tutor assume um caminho multifacetado, onde o viés administrativo surge diante das questões de cunho pedagógico, trazendo à tona a necessidade de compreendermos as competências necessárias para o exercício da função do tutor.

O conceito de competência é amplo e muito debatido no campo da pesquisa em Educação. Autores de diversas linhas de pesquisa discutem sobre o conceito e apresentam diferentes definiçõos.

Segundo FLEURY; FLEURY (2001): 
Competência é uma palavra do senso comum, utilizada para designar uma pessoa qualificada para realizar alguma coisa. $\mathrm{O}$ seu oposto, ou o seu antônimo, não implica apenas a negação desta capacidade, mas guarda um sentimento pejorativo, depreciativo. Chega mesmo a sinalizar que a pessoa se encontra ou se encontrará brevemente marginalizada dos circuitos de trabalho e de reconhecimento social ( $\mathrm{p}$. 2).

TENÓRIO et.al. (2015) destacam a necessidade de o tutor desenvolver competências específicas para a sua atuação nas diversas dimensões do seu trabalho:

O tutor é um educador que comumente assume o papel de professor a distância e precisa desenvolver competências específicas para sua atuação em diversas dimensões, como pedagógica, técnica, gerencial, tecnológica e socioafetiva (BERNARDINO, 2011; TENÓRIO;SOUTO;TENÓRIO, 2014; TEIXEIRA et.al. 2015). Na EaD, ele atua como mediador da aprendizagem dos alunos e deve promover a interação (p. 57).

Para CAMPOS (2009), “em síntese, competência é a capacidade de o sujeito mobilizar recursos para resolver uma série de situações" (p.272).

Nesse sentido, cabe destacar que o termo "competência" utilizado nesta dissertação é baseado nos estudos de CAMPOS (2009) que aborda o conceito de competência a partir da visão de alguns autores como PERRENOUD (2000), FLEURY et. al. (2001) e HERNANDEZ (2002).

Na concepção de PERRENOUD et al. (2002) temos, por exemplo:

Atualmente, define-se uma competência como a aptidão para enfrentar um conjunto de situações análogas, mobilizando de uma forma correta, rápida, pertinente e criativa, múltiplos recursos cognitivos: saberes, capacidades, microcompetências, informações, valores, atitudes, esquemas de percepção de avaliação e de raciocínio (p. 19).

A escolha do termo "competência" utilizado por CAMPOS (2009) se justifica pela aproximação que a autora faz do termo com o nosso objeto de pesquisa. Trata-se de uma compreensão mais ampla no que se refere às competências voltadas para a prática de tutoria na Educação à Distância.

Segundo os estudos de CAMPOS (2009), os referidos autores definem o conceito de competência da seguinte forma: 
- Capacidade de mobilizar diversos recursos cognitivos para enfrentar situações (PERRENOUD, 2000);

- Um saber agir responsável e reconhecido que implica mobilizar, integrar e transferir os conhecimentos, recursos, habilidades (FLEURY et. al, 2001);

- Conjunto de saberes e capacidades incorporadas por meio da formação e da experiência, somados à capacidade de integrá-los, utilizá-los e transferi-los em diferentes situações (HERNANDEZ, 2002).

As definições dos autores citados por CAMPOS (2009) apontam para alguns conceitos em comum: (1) mobilização, (2) aplicação de recursos e (3) solução de problemas.

Nesse sentido, as definições apresentadas pelos autores citados evidenciam a necessidade de o tutor apresentar uma postura diferenciada no que se refere a sua formação.

Para CAMPOS (2009), "a formação dos indivíduos deve ser voltada para a inovação, e há evidências de que o desenvolvimento de novas competências é fato constante" (p. 273).

Ainda no âmbito das competências necessárias à função do tutor e da necessidade dele dominar competências relacionadas aos princípios de interatividade, SILVA (2008) considera que:

Os princípios da interatividade podem ser encontrados em sua complexidade nas disposições técnicas do computador online. São três basicamente: a) participaçãointervenção: participar não é apenas responder "sim" ou "não" ou escolher uma opção dada, supõe interferir no conteúdo da informação ou modificar a mensagem; b) bidirecionalidade-hibridação: a comunicação é produção conjunta da emissão e da recepção, é co-criação, os dois pólos codificam e decodificam; c) permutabilidade-potencialidade: a comunicação supõe múltiplas redes articulatórias de conexões e liberdade de trocas, associações e significações.

Diante disso, elaboramos um quadro teórico a partir da revisão de literatura realizada e selecionamos as principais competências destacadas pelos autores que fazem parte do nosso estudo.

Observando as competências listadas na tabela 02 do quadro teórico é possível identificar convergências entre elas. Nesse sentido, o acompanhamento e auxílio frente às dúvidas dos alunos, a participação nos processos de avaliação e o 
domínio dos conteúdos do curso aparecem nas definições listadas com frequência

e surge como competências fundamentais para o exercício da função de tutor.

\begin{tabular}{|c|c|}
\hline \multicolumn{2}{|c|}{ QUADRO TEÓRICO DAS COMPETÊNCIAS DOS TUTORES } \\
\hline CAMPOS; AMARAL (2011) & $\begin{array}{l}\text { - Realizar atividade essencialmente individualizada e permanente no } \\
\text { - } \quad \text { Acompanhar e oferecer ao aluno todo o auxílio necessário ao processo } \\
\text { de aprendizagem, incentivando-o a realizar as tarefas propostas é o } \\
\text { seu objetivo; } \\
\text { - Contribuir para o estabelecimento de relações entre os conhecimentos } \\
\text { adquiridos e as situações concretas, facilitando a solução das } \\
\text { dificuldades encontradas; } \\
\text { - Estabelecer contato com os alunos por meio das ferramentas } \\
\text { comunicacionais (grupos, listas de discussão, correio-eletrônico e chat); } \\
\text { Verificar o grau de satisfação do aluno com o curso por métodos } \\
\text { estatísticos, fichas de avaliação e de observação. }\end{array}$ \\
\hline NUNES (2013) & $\begin{array}{l}\text { - Atuar diretamente com os alunos, sanando suas dúvidas; } \\
\text { - } \quad \text { Avaliar os alunos, tentando identificar suas dificuldades, mediando o } \\
\text { processo de aprendizagem; } \\
\text { - Utilizar os mais diferentes recursos; } \\
\text { - Planejar e orientar debates entre alunos quer presencial ou } \\
\text { virtualmente. }\end{array}$ \\
\hline \begin{tabular}{|lr} 
REFERENCIAIS & DE \\
QUALIDADE & PARA \\
EDUCAÇÃO SUPERIOR & A \\
DISTÂNCIA (2007) &
\end{tabular} & $\begin{array}{l}\text { - Esclarecer dúvidas através dos fóruns de discussão pela internet, pelo } \\
\text { telefone, participação em videoconferências, entre outros, de acordo } \\
\text { com o projeto pedagógico; } \\
\text { - Promover espaços de construção coletiva de conhecimento, selecionar } \\
\text { material de apoio e sustentação teórica aos conteúdos; } \\
\text { - Participar dos processos avaliativos de ensino-aprendizagem junto com } \\
\text { os docentes; } \\
\text { - Manter-se em permanente comunicação tanto com os estudantes } \\
\text { quanto com a equipe pedagógica do curso. }\end{array}$ \\
\hline CASTRO (2013) & $\begin{array}{l}\text { - } \quad \text { Dar voz e vez aos alunos (modelo comunicacional); } \\
\text { - } \quad \text { Incentivar a cooperação e a aprendizagem colaborativa; } \\
\text { a liberdiar os alunos a conviver com a flexibilidade, com a diferença e com } \\
\text { aúltiplas entradas e conexões. }\end{array}$ \\
\hline MENDES (2013) & $\begin{array}{ll}\text { - } & \text { Esclarecer as dúvidas dos alunos; } \\
\text { - } \quad \text { Realizar o acompanhamento dos alunos; } \\
\text { - } \quad \text { Realizar a correção de trabalhos. } \\
\end{array}$ \\
\hline MILL et. al (2008) & $\begin{array}{l}\text { - } \quad \text { Acompanhar os alunos em seus estudos; } \\
\text { - } \quad \text { Trabalhar a autonomia do aluno; } \\
\text { - } \quad \text { Orientar os alunos em suas dificuldades. } \\
\end{array}$ \\
\hline ALONSO (2010) & $\begin{array}{l}\text { - } \quad \text { Acompanhar o aluno, trabalhando cotidianamente com ele; } \\
\text { - } \quad \text { Participar dos processos de avaliação das aprendizagens. }\end{array}$ \\
\hline TENÓRIO et.al. (2015) & $\begin{array}{l}\text { - Desenvolver competências (em sua atuação) pedagógicas, técnicas, } \\
\text { gerenciais, tecnológicas e socioafetivas. }\end{array}$ \\
\hline MACHADO; MACHADO (2004) & $\begin{array}{l}\text { - } \quad \text { Conhecer com profundidade os assuntos relacionados com a matéria e } \\
\text { - } \quad \text { Planejar, acompanhar e avaliar atividades; } \\
\text { - Ter a capacidade de ouvir os alunos; } \\
\text { - Motivar o aluno para o estudo. }\end{array}$ \\
\hline SILVA (2008) & $\begin{array}{l}\text { - } \quad \text { Participar e intervir; } \\
\text { - Saber lidar com a bidirecionalidade-hibridação, ou seja, dominar a } \\
\text { emissão e a recepção de informações; } \\
\text { - Saber lidar com a permutabilidade-potencialidade, dominando as } \\
\text { múltiplas redes articulatórias de conexões e significados. }\end{array}$ \\
\hline
\end{tabular}


A partir das competências listadas percebe-se que o tutor precisa reunir a capacidade de mobilizar recursos necessários para conseguir lidar com situações relacionadas ao universo de ensino-aprendizagem online. Percebe-se também, a partir do quadro teórico exposto, que as ações que envolvem a prática de tutoria são peculiares à modalidade de ensino a distância, o que automaticamente, requer do tutor competências específicas que atendam as características dessa modalidade de ensino.

Nessa mesma direção CAMPOS (2009) ressalta que:

A definição de competência como a capacidade de o sujeito mobilizar os recursos necessários para o enfrentamento de novas situações e a consequente mobilização de suas estruturas conceituais está em estreita relação com algumas características da educação a distância (Campos, 2000), entre elas, o aprendizado autônomo e flexível - o aluno se torna responsável pelo seu processo de aprendizado à medida que decide quando e como quer aprender (p. 273).

Nesse sentido, CAMPOS (2009) apresenta o aprendizado autônomo e flexível como uma das características da Educação a Distância. Para tanto, vemos que é necessário que o tutor mobilize recursos necessários para lidar com essa e outras características do universo da Educação a Distância.

Sobre essa necessidade, CAMPOS; AMARAL (2011) destacam que em cursos a distância a realização de tarefas semelhantes as que foram descritas no quadro teórico é um dos fatores mais importantes para a seleção dos profissionais que se candidatam para trabalhar como tutor, sendo necessário que os mesmos tenham um perfil que atenda a essa necessidade.

Originalmente, o tutor tem como função principal o atendimento aos alunos, no sentido de esclarecer dúvidas quanto aos conteúdos ou a verificação do cumprimento das tarefas propostas. Entretanto, a interação com os alunos vai exigir do tutor estratégias que viabilizem ações que ultrapassam o universo da função original.

Para CASTRO (2013):

(...) o tutor não mais tutora ou assegura o cumprimento das tarefas de cada aluno, mas ele passa mediar as discussões e o conhecimento entrelaçado uns com outros, sendo assim o principal responsável pela mediação pedagógica (p.48). 
Dessa maneira, o tutor precisa fazer uso de competências que garanta o andamento do processo de aprendizagem dos alunos, indo além do esclarecimento de dúvidas, sendo necessário que o tutor também possua competências para mediar o processo de aprendizagem dos alunos, fazendo uso das tecnologias que instrumentalizam todo o processo no universo virtual de aprendizagem.

De acordo com CASTRO (2013) “a mediação pedagógica é reconhecida como principal estratégia no processo de ensino-aprendizagem da educação a distância" (p.22). Entretanto, a autora ressalta que a mediação deve acontecer entre alunos e professores, "estabelecendo as tecnologias da informação como uma estratégia pedagógica e não um fim em si mesmo” (p.22).

NUNES (2013) também menciona a tecnologia como instrumento de mediação entre alunos e tutores, reforçando a ideia do uso da tecnologia como estratégia pedagógica, diminuindo a distância física e temporal entre eles:

O uso da tecnologia no processo de mediação vai requerer do tutor competências que o permitam "usar os mais diferentes recursos (texto, som, vídeo, fórum, chat, videoconferência etc.) para se fazer compreender" (NUNES, 2013, p. 2).

Primeiramente deve-se considerar que na EaD existe uma distância física e temporal entre alunos e tutores, e a tecnologia está presente como instrumento de mediação. Isso exige uma nova postura tanto na parte do aluno como na parte do tutor (p. 2).

Quando falamos do uso da tecnologia como estratégia pedagógica, surge a questão da utilização das ferramentas online e off-line e suas múltiplas interferências no processo de aprendizagem dos alunos, uma vez que a utilização dessas ferramentas vai exigir competências que viabilizem a interação dos alunos com os conteúdos.

Nesse sentido, SILVA (2008) destaca que:

Portanto, o computador online não é um meio de transmissão de informação como a televisão, mas espaço de adentramento e manipulação em janelas móveis, plásticas e abertas a múltiplas conexões entre conteúdos e interagentes geograficamente dispersos. Para além das interferências, manipulações e modificações nos conteúdos presentes na tela do computador off-line, os interagentes podem interagir realizando compartilhamentos e encontros de colaboração síncronos e assíncronos (p.70). 
Além das competências necessárias para utilizar a tecnologia como estratégia pedagógica, cabe também mencionar as características apresentadas no quadro teórico das competências relacionadas ao conhecimento teórico-prático e que devem fazer parte das ações dos tutores. Segundo MACHADO; MACHADO (2004), a formação teórica do tutor deve estar atualizada frente a sua formação prática, uma vez que:

Este necessita entender a estrutura do assunto que ensina, os princípios da sua organização conceitual e os princípios das novas idéias produtoras de conhecimento na área. Sua formação teórica sobre o âmbito pedagógico-didático deverá ser atualizada com a formação na prática dos espaços tutoriais (p.3).

Considerando as competências destacadas pelos autores do quadro teórico apresentado, o tutor precisa fazer uso das mesmas tendo em vista que ele vai lidar com questões vinculadas ao dia-a-dia dos alunos e que não estão diretamente atreladas aos conteúdos específicos, mas sim, as questões de vínculo afetivoemocional, dentre elas, o desencanto pelo saber, a vontade de abandonar o curso entre outras.

Nesse contexto, cabe ao tutor ultrapassar os limites do domínio dos conteúdos específicos, mas deter também outras competências relacionadas à comunicação com os alunos, aos instrumentos metodológicos específicos da educação a distância e à utilização de ferramentas que devem fazem parte da mediação no sentido de verificar o grau de satisfação dos alunos em relação ao curso, para tentar evitar que as questões de vínculo afetivo-emocional, como o desencanto pelo saber, interfiram no processo de aprendizagem.

Para CAMPOS (2011):

O mediador pedagógico, ao acompanhar o processo de ensino-aprendizagem, deve verificar também o grau de satisfação do aluno com o curso por métodos estatísticos, fichas de avaliação e de observação (p. 54).

As competências listadas evidenciam a importância dos múltiplos papéis desempenhados pelos tutores, tornando-os participantes indispensáveis no processo de aprendizagem dos alunos do ensino a distância. 


\section{3.}

Tutoria versus docência à luz da legislação da Educação a Distância: diálogos, limites e tensões

$O$ aumento da oferta de cursos a distância tem levado profissionais, de formação distinta, a assumirem a função de tutor. Muitos desses sujeitos realizam esta tarefa sem preparo pedagógico específico, atuando apenas como "estimuladores" (estimulam leituras, debates, trabalhos colaborativos $e \quad o$ cumprimento dos prazos de entrega de trabalhos) e "informante" (dão informações administrativas). Assim, o tutor acaba se limitando a atuar como "porta-voz" de professores e coordenadores de curso. Seria esse o seu papel? (VILARINHO; CABANAS, P. 482, 2008).

A Educação a Distância traz em sua essência diversos aspectos que merecem reflexões e estudos mais detalhados, dentre quais, destaca-se a figura do mediador pedagógico, geralmente conhecido como tutor, cujas funções não estão claramente definidas no cenário da Educação a Distância, assim como também, nas discussões sobre o trabalho docente.

As questões levantadas por VILARINHO; CABANAS (2008) na epígrafe, nos levam a refletir sobre a necessidade de uma legislação que apresente não só as garantias de boas condições de trabalho, mas que também delimitem a formação e as funções do tutor. Ao mesmo tempo, as autoras fazem um questionamento sobre qual seria o papel do tutor, uma vez que ele acaba assumindo funções administrativas ou respondendo por outros personagens que participam do processo de planejamento dos cursos na modalidade a distância, deixando transparecer uma multiplicidade de papéis que colaboram para a indefinição das especificidades das atribuições do tutor.

Nesse sentido, percebe-se que a questão envolvendo a identidade do tutor representa uma problemática, ocasionada por algumas lacunas nas leis e decretos específicos que amparam essa função, assim como também sobre as condições de trabalho desse ator, interferindo de forma significativa na construção de uma identidade profissional que legitime a função do tutor.

Considerando a importância de um entendimento mais amplo sobre a identidade do tutor e o papel que ele ocupa no universo da Educação a Distância e buscando responder sobre a relação entre os documentos oficiais que fazem 
referência à tutoria no Brasil e a construção da identidade do tutor, optamos pela realização de uma análise sobre materiais que regem e norteiam a Educação a Distância no Brasil. Dessa forma, selecionamos como pano de fundo para a análise os seguintes materiais:

- O Decreto $n^{\circ} 5.622$ de 19 de dezembro de 2005, que regulamenta o art. 80 da Lei n ${ }^{\circ}$ 9.394, de 20 de dezembro de 1996;

- O Decreto $n^{\circ}$ 6.303, de 12 de dezembro de 2007, que apresenta alterações nos dispositivos do Decreto $\mathrm{n}^{\circ}$ 5.622;

- Os Referenciais de Qualidade para Educação Superior a Distância (2007);

- A Resolução do Conselho Deliberativo (CD)/ Fundo Nacional de Desenvolvimento da Educação - FNDE (2009);

- O Regimento interno da Fundação Centro de Ciências e Educação Superior a Distância do Estado do Rio de Janeiro (2010);

- Os dois últimos editais de seleção pública destinada à concessão de bolsas a tutores presenciais e a distância para atuação nos cursos de graduação 2015.2;

- A Convenção Coletiva (2014) firmada entre o Sindicato dos Professores do Município do Rio de Janeiro (SIMPRO-RIO) e o Sindicato das Entidades Mantenedoras de Estabelecimento de Ensino Superior do Estado do Rio de Janeiro (SEMERJ) - que discutem as atribuições e o regime de trabalho do tutor a distância;

- O Instrumento de Avaliação Externa (2010) utilizado pelas comissões avaliadoras das Instituições de Ensino Superior (presenciais e a distância).

- O Instrumento de Avaliação Externa (2014) utilizado pelas comissões avaliadoras das Instituições de Ensino Superior (presencial).

- Edital para seleção de Tutores para os cursos de graduação do Consórcio CEDERJ. Fundação Cecierj (2015);

- O Projeto de Lei n ${ }^{\circ}$ 2435/2011 - Dispõe sobre a regulamentação do exercício da atividade de Tutoria em Educação a Distância. 
O primeiro documento do levantamento de materiais é a Convenção Coletiva firmada entre o Sindicato dos Professores do Município do Rio de Janeiro (SIMPRO-RIO) e o Sindicato das Entidades Mantenedoras de Estabelecimento de Ensino Superior do Estado do Rio de Janeiro (SEMERJ), de abril de 2014. Trata-se do único documento que atribui às ações de tutoria a função docente, inclusive através da nomenclatura professor-tutor, utilizada ao longo do documento para especificar a função, assim como foi verificado na Cláusula 28 ${ }^{\mathrm{a}}, \mathrm{n}^{\mathrm{o}}$ 28.2.2, que se refere à Educação a Distância:

28.2.2 - As atribuições do professor-tutor a distância são:

a - Orientar e acompanhar a participação dos alunos nas atividades propostas no ambiente virtual de aprendizagem;

b - Avaliar o desempenho dos alunos mediante provas, trabalhos e participação em atividades interativas;

c - Orientar os alunos nos meios de comunicação disponíveis, dentro dos prazos e das cargas-horárias previamente estabelecidos;

$\mathrm{d}$ - avaliar e corrigir as atividades avaliativas dentro dos prazos e das cargashorárias estabelecidos;

e - Orientar os alunos dentro do prazo e da carga-horária definidos no modelo de EAD adotado pela instituição;

f - Elaborar relatórios com indicação dos índices de evasão e de aprovação nas atividades desenvolvidas;

$\mathrm{g}$ - Exercer todas as atividades inerentes à função de professor-tutor a distância;

$\mathrm{h}$ - Adequar-se às novas tecnologias de ensino-aprendizagem;

i - Exercer atividades de pesquisa e extensão (Convenção Coletiva, 2014).

O Decreto de $\mathrm{n}^{\circ}$ 5.622, de 19 de dezembro de 2005, através do Art. 26, parágrafo IV-b, apresenta uma distinção entre tutor e professor, quando se refere às exigências para que as instituições vinculadas possam realizar as atividades específicas para a oferta de cursos na modalidade a distância, especificamente, no que se refere à capacitação de tutores e professores:

Art. 26. As instituições credenciadas para oferta de cursos e programas a distância poderão estabelecer vínculos para fazê-lo em bases territoriais múltiplas, mediante a formação de consórcios, parcerias, celebração de convênios, acordos, contratos ou outros instrumentos similares, desde que observadas as seguintes condições:

IV - indicação das responsabilidades pela oferta dos cursos ou programas a distância, no que diz respeito a:

a) implantação de polos de educação a distância, quando for o caso;

b) seleção e capacitação dos professores e tutores (BRASIL, 2005).

Nessa mesma direção, a Resolução CD/FNDE no 26, de 5 de junho de 2009 , não se refere ao tutor como professor, muito embora a resolução mencione a 
exigência de experiência no magistério do ensino básico ou superior para o exercício das atividades de tutoria:

[...] possuir formação de nível superior e experiência mínima de um ano no magistério do ensino básico ou superior. Caso não comprove essa experiência, deve comprovar formação pós-graduada ou vinculação a programa de pósgraduação para poder exercer a função e fazer jus à bolsa mensal no valor de R \$ 765,00 (setecentos e sessenta e cinco reais). (BRASIL, 2009).

Concomitantemente a essa questão, a Fundação Centro de Ciências e Educação Superior a Distância do Estado do Rio de Janeiro (2010), apresenta em seu Regimento Interno (2010) uma definição não muito clara acerca da função do tutor, dividindo-a em duas modalidades: a tutoria presencial e a tutoria a distância. Entretanto, cabe destacar que o contato com os alunos é evidenciado na descrição das suas atribuições, deixando transparecer uma relação voltada para a docência, e não apenas vinculada ao viés burocrático:

Parágrafo Único - A tutoria se dará em duas modalidades:

I - Tutoria Presencial, que será realizada nos polos regionais, quando os alunos contarão com sessões semanais de encontro presencial para disciplinas iniciais dos cursos de graduação, ou com outra periodicidade proposta pelas coordenações, em função das especificidades de cada curso.

II - Tutoria a distância, que será realizada por meio de fax, telefone ou Internet (FUNDAÇÃO CECIERJ, p.28, 2010).

O Decreto $\mathrm{n}^{\circ}$ 6.303, de 12 de dezembro de 2007, que apresenta alterações nos dispositivos do Decreto $\mathrm{n}^{\circ}$ 5.622, no Artigo 26, parágrafo IV, define as indicações pela oferta de cursos ou programas a distância, apresentando no item "b" uma diferenciação entre professores e tutores, no que se refere à seleção e capacitação:

Art. 26. As instituições credenciadas para oferta de cursos e programas a distância poderão estabelecer vínculos para fazê-lo em bases territoriais múltiplas, mediante a formação de consórcios, parcerias, celebração de convênios, acordos, contratos ou outros instrumentos similares, desde que observadas as seguintes condições:

IV - indicação das responsabilidades pela oferta dos cursos ou programas a distância, no que diz respeito a:

a) implantação de polos de educação a distância, quando for o caso;

b) seleção e capacitação dos professores e tutores;

c) matrícula, formação, acompanhamento e avaliação dos estudantes;

d) emissão e registro dos correspondentes diplomas ou certificados (Brasil, 2007). 
Diante desse panorama, em consonância com as questões levantadas na leitura preliminar das leis e decretos apresentados, observa-se que as atribuições do tutor se entrelaçam, em alguns momentos, com a função docente. Muito embora as questões de cunho burocrático, como atendimento telefônico e a utilização de fax estejam diretamente relacionadas à sua função, evidenciando a indefinição das atribuições do tutor e, consequentemente, da sua identidade profissional.

Os dois últimos editais de seleção pública destinados à concessão de bolsas a tutores presenciais e a distância para atuação nos cursos de graduação do CEDERJ (2015), especificam a função do tutor em presencial e a distância e reforçam o entrelaçamento da função do tutor com a função docente, destacando atividades que se aproximam diretamente ao trabalho docente, como por exemplo, trabalhar diretamente com os conteúdos da disciplina, participar da aplicação das avaliações e da construção dos gabaritos etc.

Ao observarmos as atribuições elencadas nos dois últimos editais foi possível perceber que estes orientam o trabalho dos tutores a partir de ações inerentes à função docente como, por exemplo, planejar, avaliar, corrigir provas e interagir com os alunos sobre os conteúdos das diversas disciplinas que pretendem atuar.

Corroborando a definição de GATTI (2009) sobre docência adotada para este estudo, em que a docência é estabelecida por "um saber que alia conhecimento e conteúdos à didática e às condições de aprendizagem para segmentos diferenciados, educação para ser humano se faz em relações humanas profícuas" (p.91).

A tabela abaixo elenca as atribuições que os tutores presenciais devem desenvolver de acordo com o último edital do processo seletivo para tutores do CEDERJ (2015).

É possível perceber que as atribuições entre tutoria e docência se entrelaçam, uma vez que avaliar, planejar, corrigir, aplicar provas, orientar monografias e trabalhos de conclusão de curso e interagir com os alunos sobre os conteúdos das disciplinas dos cursos são ações recorrentes para o desempenho da função de tutor presencial do CEDERJ: 


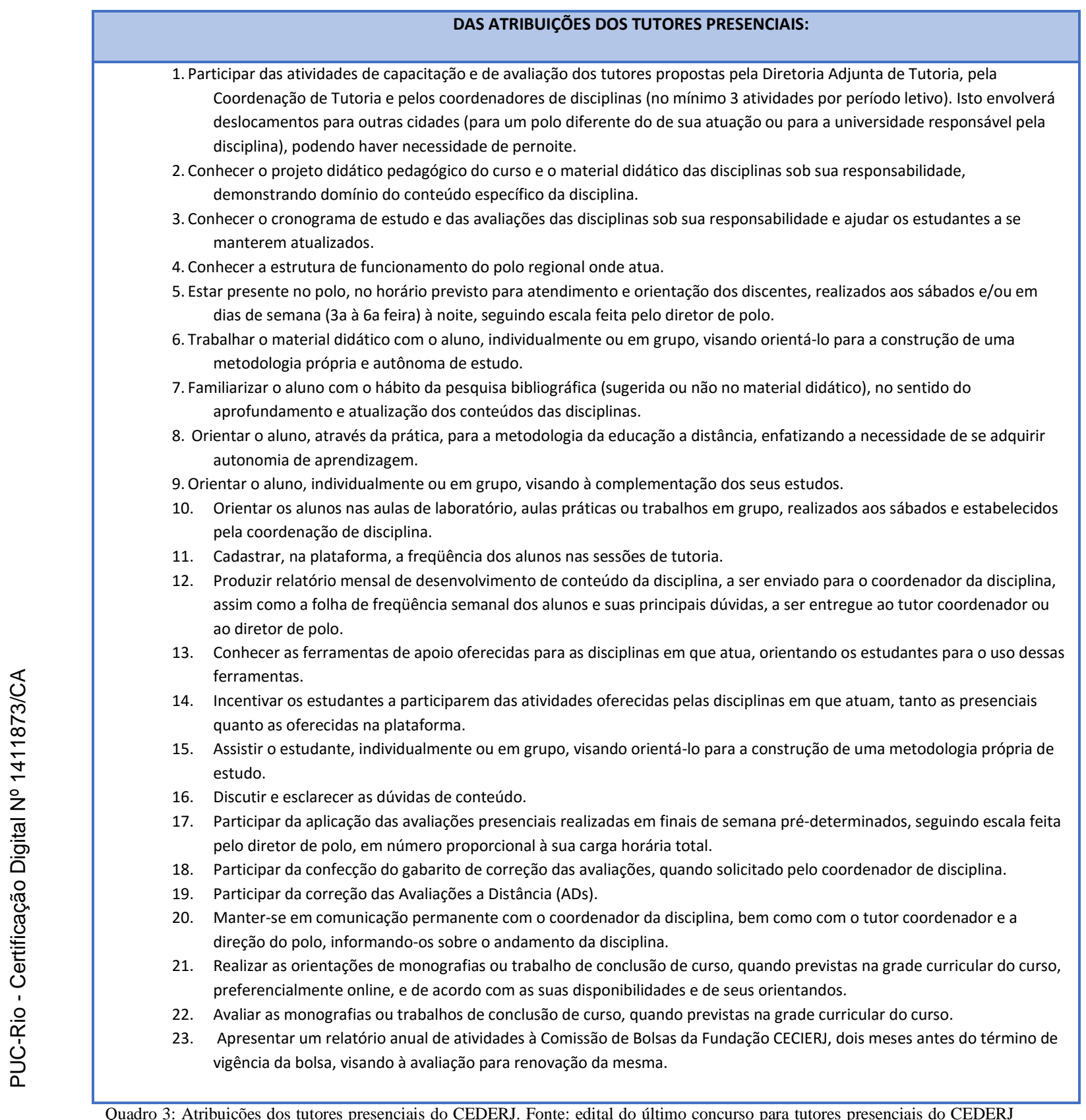

(2015). Disponível em: http://cederj.edu.br/fundacao/wp-content/uploads/2015/05/Edital-Tutor-Presencial-2015.2.pdf.

As mesmas atribuições recorrentes que se relacionam com ações docentes, como avaliar monografias, planejar, orientar os alunos frente aos conteúdos da disciplina, corrigir provas, entre outras atividades, que também foram encontradas na tabela anterior, aparecem nas atribuições dos tutores a distância do CEDERJ, segundo o último edital do processo seletivo para tutores (2015), conforme podemos verificar na tabela 4 : 
1. Participar das atividades de capacitação/avaliação de tutores propostas pela Diretoria Adjunta de Tutoria e pelas coordenações de tutoria dos cursos e coordenadores de disciplina.

2. Conhecer o projeto didático pedagógico do curso e o material didático da disciplina sob sua responsabilidade, demonstrando domínio do conteúdo da área.

3. Conhecer o cronograma de estudo e das avaliações das disciplinas sob sua responsabilidade e ajudar os estudantes a se manterem atualizados.

4. Conhecer a estrutura de funcionamento da sala de tutoria da universidade onde atua.

5. Cumprir com pontualidade os horários de atendimento aos alunos na sala de tutoria das universidades, de acordo com o estabelecido pela Coordenação do Curso e Diretoria Adjunta de Tutoria, bem como as tarefas designadas pela Coordenação do Curso.

6. Atender as consultas dos estudantes, sempre incentivando-os a encontrar a resposta e certificando-se de que a dúvida foi sanada.

7. Orientar os alunos, para o método de educação à distância, enfatizando a necessidade de se adquirir autonomia de aprendizagem e sobre a importância da utilização de todos os recursos oferecidos para a aprendizagem.

8. Encorajar e auxiliar os estudantes na busca de informações adicionais nas mais diversas fontes de informação: bibliotecas virtuais, endereços eletrônicos, bibliotecas, etc.

9. Comunicar-se com os alunos que não procuram a tutoria a distância ou ausentes nas avaliações, através de email/telefone, encorajando-os a recorrer à tutoria a distância/presencial como um auxílio no processo de aprendizagem.

10. Auxiliar o professor coordenador de disciplina na oferta de oportunidades de aprendizagem através da plataforma (fórum, "chats", construção de páginas da disciplina, formação de grupos de estudo virtuais, etc), acompanhando e atualizando as informações pertinentes à sua disciplina na plataforma.

11. Emitir relatórios periódicos com o registro da participação do estudante, suas principais dúvidas e respectivas orientações e encaminhamentos e registros de informações sobre os tipos e os níveis de dificuldades que os estudantes apresentam em relação a tópicos das disciplinas e respectivo material didático.

12. Auxiliar o professor coordenador de disciplina na elaboração, preparação e teste de atividades práticas presenciais.

13. Participar da correção das avaliações tanto presenciais como a distância, bem como da elaboração de gabaritos, sempre que solicitado.

14. Participar do processo de avaliação do material didático do CEDERJ, quando solicitado.

15. Participar das visitas presenciais aos polos, sempre que solicitados pelas Coordenações.

16. Participar de encontros, atividades culturais, videoconferências, videotutorias e seminários presenciais programados pela coordenação do curso.

17. Realizar as orientações de monografias ou trabalho de conclusão de curso, quando previstas na matriz curricular do curso, preferencialmente on-line, e de acordo com as suas disponibilidades e de seus orientandos.

18. Avaliar as monografias ou trabalhos de conclusão de curso, quando previstas na matriz curricular do curso.

19. Apresentar um relatório anual de atividades à Comissão de Bolsas da Fundação CECIERJ dois meses antes do término de vigência da

Quadro 4: Atribuições dos tutores presenciais do CEDERJ. Fonte: edital do último concurso para tutores a distância do CEDERJ

(2015). Disponível em: http://cederj.edu.br/fundacao/wp-content/uploads/2015/05/Edital-Tutor-a-Dist\%C3\%A2ncia-2015.2.pdf

Nessa mesma direção, MILL et. al. (2010) corroboram as questões levantadas neste estudo, fortalecendo a ideia de que os tutores ainda não são compreendidos dentro das suas especificidades, o que sugere a necessidade de ampliação de estudos sobre a temática:

(...) novas formas de ensinar e aprender foram geradas e, portanto, profissionais com um novo perfil são demandados. Além disso, observamos o surgimento de uma nova classe de trabalhadores ainda não compreendida suficientemente: os tutores virtuais (p. 75). 
A partir dos documentos analisados, percebe-se que a ação docente na educação a distância se entrelaça ao trabalho de tutoria, dificultando a diferenciação entre tutoria e docência. Sobre essa questão, ALONSO (2010) enfatiza que:

Se o tutor é quem acompanha o aluno, trabalha cotidianamente com ele, participa dos processos de avaliação das aprendizagens, do curso etc., conforme atribuição descrita há pouco, a pergunta é: no que essas atribuições são diferentes das docentes? (...) A discussão sobre o papel do docente na $\mathrm{EaD}$, por conseguinte daquele que poderia junto com ele desenvolver atividades de formação, seria essencial para a consolidação da modalidade (ALONSO, 2010, p.1330).

A questão do vínculo entre o tutor e as Instituições de Ensino Superior também surge como mais um elemento a ser analisado. Os tutores não possuem um vínculo com garantias trabalhistas e são contratados como bolsistas temporários, assumindo a função por dois anos, podendo renovar por mais dois. De acordo com a Resolução CD/FNDE n ${ }^{\circ}$, de 30 abril de 2010, são pagas pela UAB/CAPES quantias de $\mathrm{R} \$ 1.100,00$ ou $\mathrm{R} \$ 1.300,00$ ao professor-pesquisador, que coordena a disciplina e, para o tutor, a bolsa corresponde a $\mathrm{R} \$ 765,00$, independente se for graduado, especialista, mestre ou doutor. Além dessa diferença significativa nos valores pagos, a ausência de uma relação de trabalho que garanta os direitos trabalhistas mínimos dos tutores evidencia de forma contundente a diferenciação entre tutoria e docência, corroborando para a legitimação da precarização do trabalho docente a distância.

Segundo MENDES (2013):

Em 2006, foi aprovada a Lei $\mathrm{n}^{\circ} 11.273$, que autoriza a concessão de bolsas de estudo e de pesquisa aos participantes de programas de formação inicial e continuada de professores para a educação básica. Nessa lei, são estabelecidos os valores que serão pagos a todos os que atuarem na promoção do EAD. A vigência da bolsa está diretamente relacionada ao tempo de duração do curso, mas de acordo com a lei não deve ultrapassar quatro anos. O tutor não tem direito a férias, décimo terceiro salário, bem como a qualquer outro direito trabalhista (p.13).

Nesse sentido, percebe-se a ausência de um vínculo mais formal de trabalho entre os tutores e as Instituições de Ensino Superior (IES) que recebem pela UAB/CAPES, evidenciando a precarização do trabalho de tutoria, uma vez que não existe garantia dos direitos trabalhistas para o exercício da função.

Sobre a precarização do trabalho de tutoria, MENDES (2013) destaca que: 
O trabalho desempenhado pelos tutores é a expressão dessa precarização, pois ele não assegura qualquer direito a esses trabalhadores, que poderão ficar até quatro anos na função sem férias, décimo terceiro, registro em carteira. E, além de não possuírem qualquer proteção como trabalhadores, não poderão contabilizar esse tempo para a aposentadoria (p.17).

Para os tutores que recebem pelo CEDERJ, o valor mensal da bolsa é inferior ao que é pago pela UAB/CAPES, podendo variar pela carga horária trabalhada, número de alunos atendidos ou pelo modelo de tutoria exercido.

De acordo com SANTOS (2015):

Para o tutor presencial, o valor mensal da bolsa varia de acordo com a carga horária de tutoria, mas, parte de $\mathrm{R} \$ 275,00$ por mês para 2 horas semanais (8 horas mensais), podendo variar até cinco vezes mais em função do número de alunos e/ou disciplinas, de acordo com as necessidades da Fundação CECIERJ (Edital 01/2014, publicado em 24 de abril de 2014). Neste pagamento estão incluídas as aplicações de avaliações presenciais que, geralmente, ocorrem aos sábados e domingos. No caso da tutoria a distância, o valor da bolsa varia de acordo com a titulação do tutor, sendo: $\mathrm{R} \$ 513,00 /$ mês para Graduado, $\mathrm{R} \$ 544,00 /$ mês para Especialista, R\$ 575,00/mês para Mestre e R\$ 638,00/mês para Doutor, para 10 horas semanais de tutoria (Edital 02/2014, publicado em 24 de abril de 2014). As bolsas são concedidas pela Capes e pagas pelo Fundo Nacional de Desenvolvimento da Educação (FNDE), de acordo com a Resolução no 26 de 2009 e têm validade de 12 meses, podendo ser renovadas até quatro vezes, se for, assim, do interesse da CECIERJ e do bolsista (p.109).

Além da falta do vínculo trabalhista, outros indicadores que fortalecem a precarização do trabalho de tutoria aparecem como indicadores para que possamos refletir sobre o lugar que o tutor vem ocupando nos cursos a distância.

Sobre essa questão MENDES (2013) destaque que:

Além desse frágil vínculo trabalhista, a exploração informal da força de trabalho no EAD se expressa também no controle do tempo de trabalho, que se dá por meio do sistema de informática, que registra todos os acessos desses trabalhadores; na obrigação de responder as dúvidas dos alunos em 24 horas, o que inclui os finais de semana; na obrigação de permanecer com um número mínimo de alunos para não perder a bolsa (p.19).

Nessa mesma direção, LAPA; PRETTO (2010) reforçam a questão da baixa remuneração para os diferentes papéis na EAD, inclusive o de tutor, apontando para a questão da precarização do trabalho docente: 
No que concerne ao professor, as diretrizes financeiras determinam também o papel docente na $\mathrm{EaD}$. A docência, distribuída em diferentes papéis, como o de professor e o de tutor (a distância e presencial), está definida em resoluções que enquadram esses profissionais como bolsistas que sequer têm direito a uma declaração do trabalho que realizam como professores, devido à possível consolidação de vínculos empregatícios não desejados. Tal precarização do trabalho docente se desdobra, na prática, entre outras coisas, por meio da baixa remuneração, que exclui profissionais qualificados, e da falta de reconhecimento profissional (p.1).

Nesse contexto, percebe-se que essa frágil relação trabalhista não se configura como uma relação de trabalho entre tutor e as IES, uma vez que a ausência das garantias mínimas dos direitos trabalhistas demonstra que na verdade, existe uma relação de prestação de serviço fomentada pela exploração informal das atividades exercidas pelos tutores que atuam nas diferentes IES. Além do controle de tempo de trabalho, inclusive aos finais de semana mencionado por MENDES (2013), essa exploração é evidenciada pelo baixo valor das bolsas concedidas aos tutores, independente da sua formação e qualificação para exercer a função, formação essa exigida pela Resolução CD/FNDE $n^{\circ}$ 26, de 5 de junho de 2009 e pelo Instrumento de Avaliação Externa utilizado para avaliar a Educação Superior.

O Instrumento de Avaliação Externa, criado pela Lei nº 10.861, de 14 de abril de 2004, utilizado pelas comissões avaliadoras externas designadas pelo INEP que fazem uso para avaliar os cursos presenciais e a distância no País. Para tanto, o instrumento considera as seguintes dimensões:

- DIMENSÃO 1: A Missão e o Plano de Desenvolvimento Institucional;

- DIMENSÃO 2: A política para o ensino (graduação e pósgraduação), a pesquisa, a extensão e as respectivas normas de operacionalização, incluídos os procedimentos para estímulo à produção acadêmica, para as bolsas de pesquisa, de monitoria e demais modalidades;

- DIMENSÃO 3: A responsabilidade social da instituição, considerada especialmente no que se refere à sua contribuição em relação à inclusão social, ao desenvolvimento econômico e social, 
à defesa do meio ambiente, da memória cultural, da produção artística e do patrimônio cultural;

- DIMENSÃO 4: A comunicação com a sociedade;

- DIMENSÃO 5: As políticas de pessoal, de carreiras do corpo docente e corpo técnico-administrativo, seu aperfeiçoamento, seu desenvolvimento profissional e suas condições de trabalho;

- DIMENSÃO 6: Organização e gestão da instituição, especialmente o funcionamento e representatividade dos colegiados, sua independência e autonomia na relação com a mantenedora, e a participação dos segmentos da comunidade universitária nos processos decisórios;

- DIMENSÃO 7: Infraestrutura física, especialmente a de ensino e de pesquisa, biblioteca, recursos de informação e comunicação;

- DIMENSÃO 8: Planejamento e avaliação, especialmente em relação aos processos, resultados e eficácia da autoavaliação institucional;

- DIMENSÃO 9: Políticas de atendimento aos discentes;

- DIMENSÃO 10: Sustentabilidade financeira, tendo em vista o significado social da continuidade dos compromissos na oferta da educação superior.

O trabalho de tutoria é mencionado pelo Instrumento de Avaliação Externa na Dimensão 5, da seguinte forma:

5.5. Formação do corpo de tutores presenciais e suas condições institucionais (indicador exclusivo para IES credenciada para modalidade a distância - EAD). Conceito referencial mínimo de qualidade: Quando o corpo de tutores presenciais tem, no mínimo, graduação na área objeto da tutoria e as políticas para a sua capacitação estão implementadas e acompanhadas.

5.6. Formação do corpo de tutores a distância e suas condições institucionais (indicador exclusivo para IES credenciada para modalidade a distância - EAD). Conceito referencial mínimo de qualidade: Quando o corpo de tutores a distância tem, no mínimo, graduação na área objeto da tutoria e as políticas para a sua capacitação estão implementadas e acompanhadas (2010, p.11).

Os itens citados da Dimensão 5 se referem aos tutores presenciais e a distância e não apresentam diferenças relacionadas à formação exigida como referencial mínimo de qualidade, sendo um dos indicadores para que as IES sejam 
credenciadas para a modalidade a distância. Além disso, a Dimensão também cita como indicadores as políticas para a capacitação dos tutores. Dessa maneira, corroborando com a Resolução CD/FNDE n 26, de 5 de junho de 2009, o tutor precisa ter como formação mínima a graduação.

Diferentemente do Instrumento de Avaliação Externa de 2010 que se organiza por dimensões, o Instrumento de Avaliação Externa 2014 se divide em cinco eixos, considerando as especificidades das diferentes organizações acadêmicas, independente da modalidade de ensino, a partir do foco definido no Plano de Desenvolvimento Institucional (PDI) e nos processos de avaliação institucional (interna e externa).

O tutor é mencionado no Instrumento de Avaliação Externa de 2014 na parte dos mecanismos de interação entre docentes e discentes, entretanto, assim como a maioria dos documentos analisados neste tópico do trabalho, a tutoria é diferenciada da docência, mas citada como componente envolvido nos processos acadêmicos de ensino-aprendizagem:

Compõe o conjunto de estruturas de Tecnologia de Informação e Comunicação (TIC) e os respectivos procedimentos e as formas de utilização que caracterizam a dinâmica da comunicação e da interação entre os sujeitos envolvidos nos processos acadêmicos e de ensino e aprendizagem (que são, basicamente, os docentes, tutores e discentes), no contexto da oferta do curso superior na modalidade a distância. Justifica-se uma vez que os sujeitos deverão estabelecer comunicação permanente e continuada em diferentes espaços geográficos e tempos. O PPC deve explicitar esses mecanismos de modo a possibilitar ao discente a aquisição de conhecimentos e habilidades, bem como desenvolver a sociabilidade, por meio de atividades da comunicação, interação e troca de experiências. As TICs devem ser efetivas na comunicação dos envolvidos (Instrumento de Avaliação Externa de 2014, p.33)

Percebe-se nos materiais analisados que as ações docentes estão presentes no exercício da função de tutor a todo o momento e, muito embora, o distanciamento das funções de tutoria e docência fique evidenciado pelos materiais analisados, no que se refere aos papéis estabelecidos, "eliminando, assim, a possibilidade de reconhecimento do trabalho profissional do professor na modalidade a distância” (LAPA; PRETTO, 2010, p. 1-2).

Finalizando a discussão sobre os principais documentos oficiais que fazem referência à tutoria no Brasil e a construção da identidade do tutor, temos o Projeto de Lei n. 2435/2011 que ainda está em andamento e dispõe sobre a regulamentação do exercício da atividade de Tutoria em Educação a Distância. 
Trata-se de um documento em formato de projeto, que apresenta logo de início o conceito de tutoria sob a ótica do autor do Projeto de Lei: "Entende-se por tutoria na educação a distância a interação, a mediação e a facilitação do processo de ensino-aprendizagem" (PL2435/2011- Art. 3º).

Entretanto, o documento não deixa claro se o tutor deve ou não ser considerado um professor. Não existe alusão sob essa questão, no que se refere aos aspectos trabalhistas, profissional ou pedagógico.

Art. $8^{\circ}$ Fica facultado a cada uma das instituições de ensino, públicas ou privadas, a atestarem o tempo de docência do trabalho exercido pelo Tutor em Educação a Distância, respeitado o projeto político-pedagógico de cada curso (PL2435/2011Art. $\left.3^{\circ}\right)$.

O termo docência do trabalho é utilizado no Artigo $8^{\circ}$ para se referir ao tutor, muito embora perca a sua força quando o próprio artigo faculta às instituições de ensino atestar o tempo de docência do trabalho exercido pelo tutor, ou seja, transfere para as instituições de ensino o "poder" de atestar o tempo de trabalho exercido pelo tutor, que poderá continuar exercendo as atividades em tempo integral, inclusive nos finais de semana.

$\mathrm{O}$ fato do Artigo $7^{\circ}$ mencionar às 40 horas semanais, não evita que os tutores sejam explorados em horários que não deveriam estar trabalhando. A necessidade real gira em torno de uma legislação que garanta os mesmos direitos conquistados pelos docentes, no que se refere à legislação, ou seja, que mencione a forma como as horas serão distribuídas, garantindo inclusive o direito às férias, horários diferenciados para formação etc.

Outra questão que merece a nossa atenção se refere aos limites de atuação do tutor, pois mesmo apresentando alguns conceitos vinculados ao trabalho exercido pelo tutor, o texto se mostra evasivo no que se refere aos limites de atuação do tutor, além de se referir aos baixos salários de forma restrita e não apresentar um parâmetro que oriente e/ou determine um piso salarial que supere os baixos valores pagos aos tutores em todo Brasil.

Outro aspecto que chama atenção no texto se refere à diferenciação de salários entre tutores a distância e tutores presenciais, quando menciona que o tutor a distância ganha menos do que o tutor presencial. $\mathrm{O}$ trecho em destaque abaixo deixa dúvidas se a ideia seria comparar os salários do tutor com os dos 
professores do ensino presencial, pois o termo utilizado para a comparação feita é o de "tutores da educação presencial":

Contudo, a insatisfação dos tutores da educação a distância é muito grande: Seus salários são sempre menores se comparado com os valores pagos aos tutores da educação presencial; precisam dominar e reciclar constantemente o seu conhecimento dos recursos tecnológicos, utilizando adequadamente as ferramentas do espaço virtual; o preconceito, a discriminação e o descrédito são enormes, dentre outros problemas (PL2435/2011, p. 6).

O Projeto de Lei pode vir a ser percebido como um avanço na legitimação do trabalho do tutor, caso repense as referidas lacunas em seu texto, pois a sua aprovação no formato atual pode acarretar na continuidade da falta de delimitações da função de tutoria e no exercício de um trabalho precarizado sem as devidas garantias legais que possam ampará-los nas relações de trabalho e na legitimação da sua prática.

Dessa maneira, os materiais analisados deixam transparecer a lacuna que se constitui como ponto central de nossa análise: o distanciamento entre as funções de tutoria e docência, uma vez que "se o tutor é quem acompanha o aluno, trabalha cotidianamente com ele, participa dos processos de avaliação das aprendizagens, do curso (...) a pergunta é: no que essas atribuições são diferentes das docentes?" (ALONSO, 2010, p.13). 


\section{A opção metodológica}

Partindo das questões levantadas nesta pesquisa, adotamos para o desenvolvimento metodológico a abordagem qualitativa, com delineamento exploratório-descritivo, tendo em vista que o nosso objeto de análise ainda carece de discussão e estudos no campo da pesquisa em Educação, considerando que o delineamento de caráter exploratório "têm como objetivo proporcionar maior familiaridade com o problema, com vistas a torná-lo mais explícito ou a constituir hipóteses" (GIL, 2002, p. 41).

A opção de associar o caráter exploratório ao descritivo se justifica nos seguintes objetivos da pesquisa: (1) Identificar as principais características da identidade do tutor do curso de Administração do CEDERJ/UFRRJ; (2) Identificar as percepções que o tutor possui acerca do lugar que ocupa na Educação a Distância, uma vez que "entre as pesquisas descritivas, salientam-se aquelas que têm por objetivo estudar as características de um grupo" (GIL, 2002, p. 41).

A pesquisa bibliográfica também fez parte do delineamento metodológico desta pesquisa, a partir dos livros e artigos científicos que abordam o tema, assim como das fontes das leis e Decretos relacionados à Educação a Distância e a função do tutor ${ }^{16}$ no sentido de buscar informações que contribuíram nas respostas para as questões levantadas neste estudo e na análise e interpretação dos dados coletados.

\footnotetext{
${ }^{16}$ O Decreto $\mathrm{n}^{\mathrm{o}} 5.622$ de 19 de dezembro de 2005, que Regulamenta o art. 80 da Lei $\mathrm{n}^{\circ}$ 9.394, de 20 de dezembro de 1996, (2) O Decreto $\mathrm{n}^{\circ}$ 6.303, de 12 de dezembro de 2007, que apresenta alterações nos dispositivos do Decreto ${ }^{\circ}$ 5.622; (3) Os Referenciais de Qualidade para Educação Superior a Distância (2007); (4) A Resolução do Conselho Deliberativo (CD)/ Fundo Nacional de Desenvolvimento da Educação - FNDE (2009); (5) O Regimento interno da Fundação Centro de Ciências e Educação Superior a Distância do Estado do Rio de Janeiro (2010); (6) A Convenção Coletiva (2014) firmada entre o Sindicato dos Professores do Município do Rio de Janeiro (SIMPRO-RIO) e o Sindicato das Entidades Mantenedoras de Estabelecimento de Ensino Superior do Estado do Rio de Janeiro (SEMERJ) - que discutem as atribuições e o regime de trabalho do tutor a distância.
} 
Considerando a ideia de que a abordagem qualitativa não rejeita as múltiplas formas de quantificação, uma vez que os métodos qualitativos e quantitativos podem ser adotados como métodos complementares, utilizamos como instrumento de coleta de dados, a aplicação de um questionário online, buscando alcançar dados que colaboraram para alcançarmos respostas para as questões levantadas neste estudo, especificamente, as características do tutor e a sua percepção sobre o seu papel frente ao trabalho que desenvolve.

Sobre a ideia de complementariedade das abordagens qualitativas e quantitativas, DEMO (2001) ressalta que:

Todo fenômeno qualitativo é dotado também e naturalmente de faces quantitativas e vice-versa. Parto do ponto de vista de que entre quantidade e qualidade não existe dicotomia, pois são faces diferenciadas do mesmo fenômeno. Métodos quantitativos e qualitativos precisam ser tomados como complementares e como regra (p. 8).

Dessa maneira, concordando com DEMO (2001) essa pesquisa se fundamenta na ideia de complementariedade dos métodos qualitativos e quantitativos, acreditando que eles não se opõem em meio à realidade dos dados coletados.

\section{1.}

\section{A seleção da amostra}

Optamos por trabalhar no curso de Administração oferecido pelo CEDERJ desde 2006, em convênio com a Universidade Federal Rural do Rio de Janeiro. Segundo informações da secretária do curso, atualmente, 6.468 alunos estão matriculados no curso, divididos em 14 polos $^{17}$ de atendimento presencial.

A opção pelo curso de Administração deu-se pelo fato de se tratar de um dos primeiros cursos de graduação ofertados pelo CEDERJ, além de atender a um número expressivo de alunos.

Outro fator que contribuiu para a opção pelo curso de Administração do CEDERJ/UFRRJ foi a necessidade de garantir o distanciamento necessário entre a

\footnotetext{
${ }^{17}$ Angra dos Reis; Barra do Piraí; Cantagalo; Itaperuna; Macaé; Magé; Petrópolis; Piraí; Resende; Rio das Flores; Rocinha; São Fidélis; São Gonçalo e Saquarema.
} 
tríade objeto-sujeito-pesquisador, tendo em vista que como foi mencionado anteriormente, desenvolvo um trabalho de tutoria no CEDERJ, nas disciplinas pedagógicas dos cursos de licenciaturas.

\section{2.}

\section{A construção e validação do questionário aplicado}

A construção do questionário para esta dissertação teve seus indicadores e questões baseados nos Referenciais de Qualidade para Cursos a Distância ${ }^{18}$ (2007) e nos estudos teórico-metodológicos de MILL et. al (2008), OLIVEIRA (2008) CAMPOS; AMARAL (2011), CASTRO (2013), MACHADO; MACHADO (2004) NUNES (2013), MENDES (2013), ALONSO (2010) e TONNETTI (2002) no qual estes autores apontam para a necessidade de ampliação dos estudos e pesquisas sobre a identidade do tutor.

A partir dos achados nos estudos citados, percebe-se que a temática que envolve a identidade do tutor é permeada por contradições que interferem diretamente na qualidade dos cursos a distância, evidenciando a necessidade de uma percepção mais clara acerca da identidade profissional dos tutores.

Nesse contexto, as questões que nortearam a pesquisa foram delineadas e apresentadas no primeiro capítulo dessa dissertação e estão reproduzidas a seguir:

- Quais são as principais características que compõem o perfil do tutor no que se refere aos aspectos gerais e de formação?

- Quais são as percepções que o tutor possui acerca do lugar que ele ocupa na Educação a Distância?

- Qual a relação entre os documentos oficiais que fazem referência à tutoria no Brasil e a construção da identidade do tutor?

Partindo das questões da pesquisa e dos referenciais teórico-metodológicos dos estudos, construímos um questionário entregue aos respondentes em um formulário via Survey Monkey ${ }^{19}$. Optou-se por convidar todos os 117 tutores do

\footnotetext{
${ }^{18}$ Documento estabelecido pelo Ministério da Educação que define as diretrizes e os critérios para as instituições que oferecem cursos na modalidade a distância.

${ }^{19}$ É um serviço de armazenamento e sincronização de arquivos gratuitos, que permite a formatação, envio e quantificação de questionários online.
} 
curso de Administração do CEDERJ/UFRRJ ${ }^{20}$, buscando verificar: a) o perfil acadêmico-profissional; b) a percepção sobre seu trabalho e a descrição de suas interações e funções.

Sobre o envio do questionário via formulário Survey Monkey, cabe destacar que se constitui um instrumento viável, de fácil acesso, tornando possível alcançar um número razoável de participantes com facilidade, sendo um “instrumento de coleta de dados, constituído por uma serie ordenada de perguntas, que devem ser respondidas por escrito e sem a presença do entrevistador" (LAKATOS; MARCONI, 2007, p. 203).

A partir da revisão teórico-metodológica construímos um questionário autoaplicável composto inicialmente por um termo de livre consentimento e, logo em seguida, por questões fechadas de múltipla escolha, utilizando escalas de concordância e relevância, e duas questões abertas. O questionário priorizou o anonimato dos participantes, de modo que os tutores se sentissem à vontade para responder às questões propostas.

A fim de atingir a amostra selecionada composta pelos 117 tutores, foi preciso ter acesso aos e-mails dos respondentes. Conseguimos a listagem destes e-mails com a secretária do curso de administração do CEDERJ/UFRRJ, que cedeu a planilha com as informações necessárias.

O questionário foi organizado em quatro blocos de perguntas, sendo os três primeiros blocos com 23 questões objetivas, mais duas questões abertas no último bloco. Algumas questões fechadas apresentavam espaços para possíveis comentários, não obrigatórios, para especificar as respostas, como por exemplo, a formação acadêmica e outras atividades profissionais exercidas pelos tutores.

Assim, organizamos um quadro teórico com as questões que compuseram o questionário, fazendo referência aos autores que contribuíram para a fundamentação das questões elaboradas. As questões foram divididas em duas categorias, a saber: tutoria e docência a partir da literatura específica estudada.

\footnotetext{
${ }^{20}$ A coleta de dados será feita com os tutores a distância e presenciais do curso de Administração a distância do CEDERJ/UFRRJ, no sentido de, manter o distanciamento necessário entre a pesquisadora e objeto de pesquisa, tendo em vista que também desenvolvemos um trabalho de tutoria no CEDERJ, mas especificamente nos cursos de licenciatura, com as disciplinas pedagógicas. A escolha pelo curso de Administração a distância do CEDERJ/UFRRJ também se deu pelo fato de se tratar de um curso que atende um número expressivo de alunos.
} 


\begin{tabular}{|c|c|c|}
\hline \multicolumn{3}{|c|}{ QUADRO TEÓRICO DAS QUESTÕES } \\
\hline $\begin{array}{l}\text { Bloco 1: Perfil do tutor, experiência profissional e formação } \\
\text { acadêmica }\end{array}$ & Referências & Categoria \\
\hline $\begin{array}{l}\text { 1. Sua função como tutor (a) é: } \\
\text { A. ( ) presencial B. () a distância }\end{array}$ & MILL et. al (2008) & Tutoria \\
\hline 2. Qual é a sua idade? & MILL et. al (2008) & Tutoria \\
\hline 3. Formação Acadêmica & $\begin{array}{l}\text { REFERENCIAIS PARA A QUALIDADE } \\
\text { DA EAD (2007) }\end{array}$ & Tutoria \\
\hline 4. Formação Específica em EaD (sim ou não); & MILL et. al (2008) & Tutoria \\
\hline 5. Há quanto tempo você trabalha como tutor (a)? & MILL et. al (2008) & Tutoria \\
\hline $\begin{array}{l}\text { 6. Além de trabalhar como tutor (a) você possui outra } \\
\text { atividade profissional? (sim ou não); }\end{array}$ & MILL et. al (2008) & Tutoria \\
\hline $\begin{array}{l}\text { Bloco 2: A seguir posicione-se sobre cada item de acordo com a } \\
\text { sua experiência como tutor }\end{array}$ & Referências & Categoria \\
\hline 1. Conhece o projeto político-pedagógico do seu curso? & MACHADO \& MACHADO (2004) & Docência \\
\hline $\begin{array}{l}\text { 2. Com que frequência você percebe em sua interação } \\
\text { com o aluno que o mesmo apresenta uma postura } \\
\text { autônoma em relação ao processo de aprendizagem? }\end{array}$ & VILARINHO E CABANAS (2008) & Tutoria \\
\hline $\begin{array}{l}\text { 3. Com que frequência a interação com os alunos está } \\
\text { voltada para os temas específicos da sua disciplina? }\end{array}$ & OLIVEIRA et.al (2008) & Docência \\
\hline $\begin{array}{l}\text { 4. Com que frequência você utiliza com os alunos vídeos, } \\
\text { livros digitais e revistas eletrônicas para ampliar a } \\
\text { discussão sobre os temas da disciplina? }\end{array}$ & MACHADO \& MACHADO (2004) & Docência \\
\hline $\begin{array}{l}\text { 5. Na sua interação com os alunos, as questões } \\
\text { relacionadas ao universo acadêmico-administrativo do } \\
\text { curso aparecem com qual frequência? (Ex: prazos de } \\
\text { envio de trabalho, notas, datas de provas, problemas } \\
\text { gerais na plataforma, documentos e etc.) }\end{array}$ & MACHADO \& MACHADO (2004) & Docência \\
\hline $\begin{array}{l}\text { 6. Com que frequência você contribui na construção das } \\
\text { avaliações presenciais e a distância? }\end{array}$ & MACHADO \& MACHADO (2004) & Tutoria \\
\hline $\begin{array}{l}\text { 7. Com que frequência você participa do planejamento } \\
\text { de trabalhos e atividades acadêmicas da disciplina que } \\
\text { você atua? }\end{array}$ & MACHADO \& MACHADO (2004) & Tutoria \\
\hline $\begin{array}{l}\text { 8. Com que frequência você participa da construção do } \\
\text { ambiente virtual da disciplina que você atua, na } \\
\text { produção, avaliação, seleção e definição de estratégias } \\
\text { de uso dos materiais utilizados? }\end{array}$ & MACHADO \& MACHADO (2004) & Tutoria \\
\hline $\begin{array}{l}\text { 9. Você costuma utilizar as ferramentas da Plataforma } \\
\text { do Cederj durante o seu trabalho de tutoria? } \\
\text { (Exemplos: o portal Teca, ambiente de avisos, e-mail } \\
\text { do Cederj, Wiki e etc.) }\end{array}$ & OLIVEIRA et.al (2008) & Tutoria \\
\hline $\begin{array}{l}\text { Bloco 3: Percepções do tutor sobre o lugar que ele ocupa na } \\
\text { Educação a Distância }\end{array}$ & Referências & Categoria \\
\hline $\begin{array}{l}\text { 1. Sente-se responsável pelo desempenho e } \\
\text { desenvolvimento dos alunos na disciplina em que você } \\
\text { atua. }\end{array}$ & NUNES (2013) & Tutoria \\
\hline $\begin{array}{l}\text { 2. Participa da tomada de decisões concernentes ao } \\
\text { planejamento da sua disciplina. }\end{array}$ & MILL et. al (2008) & Tutoria \\
\hline $\begin{array}{l}\text { 3. Percebe a sua função com clareza, no que se refere } \\
\text { aos limites de atuação das práticas de tutoria. }\end{array}$ & CASTRO (2013) & Tutoria \\
\hline $\begin{array}{l}\text { 4. Sente-se valorizado pela instituição à qual você exerce } \\
\text { o trabalho de tutoria. }\end{array}$ & ALONSO (2010) & Tutoria \\
\hline 5. Sente-se valorizado pelos alunos do seu curso. & ALONSO (2010) & Tutoria \\
\hline $\begin{array}{l}\text { 6. Percebe a sua função como condição primordial para a } \\
\text { efetivação do processo de ensino-aprendizagem do } \\
\text { seu curso. }\end{array}$ & LAPA e PRETTO (2010) & Tutoria \\
\hline $\begin{array}{l}\text { 7. Sente-se satisfeito com o formato de vínculo de } \\
\text { trabalho entre você a instituição em que você atua. }\end{array}$ & MENDES (2013) & Tutoria \\
\hline 8. Percebe a função do tutor como função docente. & MILL et. al (2008) & Tutoria \\
\hline $\begin{array}{l}\text { Bloco final - Perguntas abertas: Percepções do tutor sobre o } \\
\text { lugar que ele ocupa na Educação a Distância }\end{array}$ & Referências & Categoria \\
\hline $\begin{array}{l}\text { Comente algo que você considere relevante na sua } \\
\text { função como tutor (a). }\end{array}$ & MILL et. al (2008) & Tutoria \\
\hline Você acredita que ser tutor (a) é profissão? & MILL et. al (2008) & Tutoria \\
\hline
\end{tabular}


No primeiro bloco, busca-se uma compreensão sobre aspectos referentes ao perfil do tutor, sua experiência profissional e formação acadêmica.

No segundo bloco, objetiva-se identificar as práticas predominantes no trabalho de tutoria e a relação do tutor com a função que exerce no contexto em que o seu trabalho está inserido.

No terceiro bloco e no bloco final, as percepções do tutor sobre a sua função e sobre o lugar que ele ocupa na Educação a Distância se constituem como centro das questões presentes.

A elaboração do segundo e do terceiro bloco do questionário foi pautada na escala de Likert, em que os tutores especificaram seu nível de concordância em cada item, considerando uma escala de concordância e relevância de 1 a 4 .

O questionário foi avaliado por um painel de especialistas no sentido de aprimorar as questões formuladas, o que acarretou mudanças significativas para a composição final do instrumento de medição. O painel foi composto por sete professores que atuam em pesquisas no campo da Educação a Distância, sendo três especialistas com a formação inicial em Pedagogia, dois especialistas com sua formação em Sociologia, um especialista em Engenharia de Sistemas e um especialista em Ciência da Computação. Cabe salientar que todos os especialistas que validaram o questionário são doutores e possuem ampla experiência na área de Educação a Distância.

O painel de especialistas considerou o questionário bem elaborado sendo que um dos especialistas apontou a necessidade de cuidar para que as perguntas não ficassem tendenciosas embora não tenha destacado nenhuma questão específica. Outro especialista apontou que seria aconselhável especificar melhor as opções de práticas da tutoria tornando-as mais usuais e naturais. Isto foi realizado no segundo bloco do questionário.

Os dados obtidos foram analisados através do SPSS (versão 2.0), um software voltado para a elaboração de análises estatísticas de matrizes de dados. A utilização desse software para o estudo auxiliou na geração de relatórios tabulados e gráficos, além da correlação entre variáveis.

A realização da análise dos dados coletados nas perguntas abertas teve como referencial a técnica de análise de conteúdo, no que se refere à modalidade de análise temática das respostas. Para BARDIN (2006), essa técnica está “entre 
as diferentes possibilidades de categorização, a investigação dos temas, ou análise temática, é rápida e eficaz na condição de se aplicar a discursos directos (significações manifestas) e simples" (p. 153).

Nesse sentido, buscou-se identificar os temas mais recorrentes dentro de duas categorias de análise: (1) As características relacionadas a experiência dos tutores, (2) As percepções do tutor sobre o lugar que ele ocupa na Educação a Distância.

\section{3.}

\section{Análise dos dados: afinal, quem é o tutor?}

É sobre esta figura que nos debruçamos. Consegue o tutor definir, com clareza, seu papel? Que formação possui para o exercício da tutoria? Que atividades desenvolve como tutor? (VILARINHO E CABANAS, P. 483, 2008).

Nesta seção é apresentada a descrição e análise dos resultados dos dados coletados através do questionário, identificando as principais características que compõem o perfil do tutor.

O questionário ficou disponível para os 117 tutores entre o período de 16/12/2015 à 15/01/2006. No total, 67 tutores responderam às perguntas, sendo que um respondente não concordou com o termo de consentimento livre e esclarecido e não deu prosseguimento ao preenchimento. Além disso, um respondente não completou todas as questões, recebendo sigla NR (Não houve resposta) nas questões que não respondeu.

No primeiro bloco de questões, buscou-se identificar os aspectos gerais e de formação, tais como idade, tipo de tutoria, formação acadêmica, tempo de experiência na área de tutoria, experiência profissional em outras instituições e informações referentes à sua interação com os alunos.

No segundo bloco, pretendeu-se descrever e analisar as principais características dos tutores, a partir das práticas predominantes no trabalho por eles desenvolvido no CEDERJ.

O terceiro bloco de questões buscou identificar as percepções dos tutores sobre o lugar que eles ocupam na Educação a Distância. Para isso, considerou-se a experiência dos tutores e a relação deles com a função que exercem no contexto em que o seu trabalho está inserido. Além da análise frequencial das questões, 
optou-se pela realização de uma análise fatorial dos resultados encontrados, uma vez que os dados coletados neste bloco de questões apresentaram resultados expressivos em relação às respostas das questões centrais deste estudo

Sobre o questionário, vale destacar que o segundo bloco considerou que as questões propostas atendem as duas funções de tutoria, presencial e a distância, de modo que, ao construir as perguntas, considerou-se o último edital do processo seletivo para tutores do CEDERJ (2015) no qual foi verificado que a função do tutor, independente de ser presencial ou a distância, orienta que eles se relacionem com os alunos e com a plataforma do CEDERJ. Sendo assim, considerou-se que os resultados apresentados neste bloco não precisavam ser tratados de forma diferenciada quando se trata sobre a utilização da plataforma CEDERJ.

\subsection{1 \\ Descrição e análise quantitativa: perfil do tutor, experiência profissional e formação acadêmica}

No primeiro bloco de questões intitulado "Perfil do tutor, experiência profissional e formação acadêmica" verificamos que o curso de Administração do CEDERJ/UFRRJ é composto por uma maioria de tutores presenciais. Assim, como está representado na tabela 6:

\begin{tabular}{|c|c|c|c|c|c|}
\hline \multicolumn{6}{|c|}{ SUA FUNÇÃO COMO TUTOR (A) É: } \\
\hline & & Frequency & Percent & Valid Percent & $\begin{array}{l}\text { Cumulative } \\
\text { Percent }\end{array}$ \\
\hline $\begin{array}{l}\text { Valid } \\
\end{array}$ & Presencial & $\overline{4}$ & 68,2 & 68,2 & 68,2 \\
\hline & Á distância & 2 & 31,8 & 31,8 & 100,0 \\
\hline & Total & 6 & 100,0 & 100,0 & \\
\hline
\end{tabular}

Tabela 1: Função dos tutores respondentes. Fonte: SPSS

Com relação à faixa etária dos tutores, a maior distribuição de idade (32,3\%) está entre as faixas dos 30 aos 35 anos e dos 36 a 44 anos (29,2\%), conforme representado no gráfico 5: 


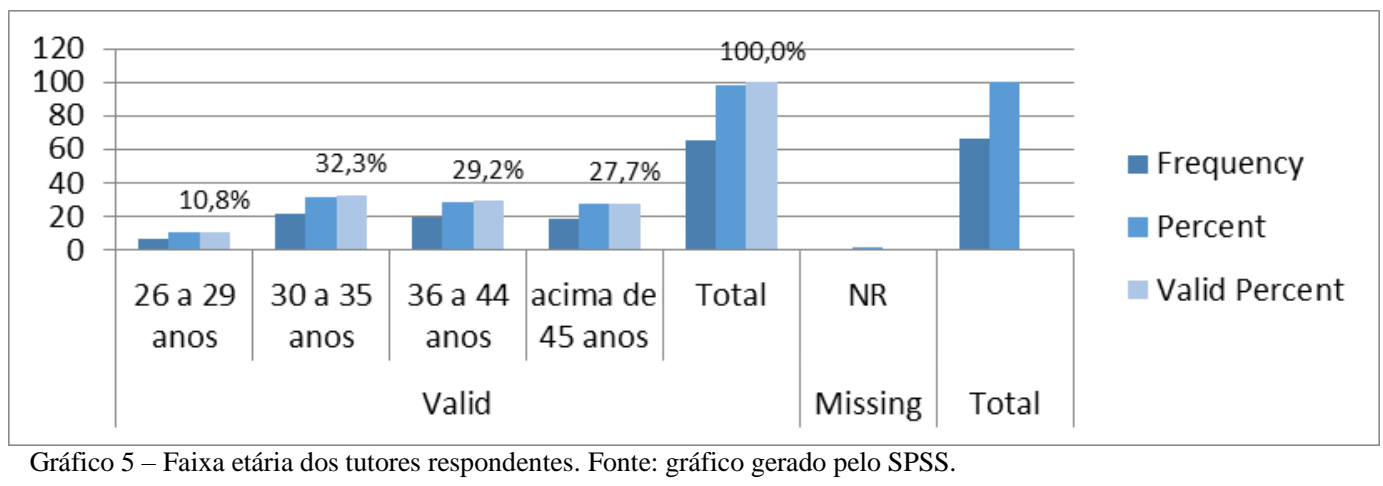

Sobre a formação dos tutores, verificamos que a maioria, $54,7 \%$, possui curso de especialização, $18,7 \%$ são graduados, $26,7 \%$ tem mestrado e nenhum tutor tem doutorado (ver tabela 7).

\begin{tabular}{|c|r|}
\hline \multicolumn{2}{|c|}{ Formação dos tutores } \\
\hline Graduação & $18,7 \%$ \\
\hline Especialização & $54,7 \%$ \\
\hline Mestrado & $26,7 \%$ \\
\hline Doutorado & $0,0 \%$ \\
\hline
\end{tabular}

Tabela 2: Formação dos tutores respondentes. Fonte: Elaboração própria.

Dessa maneira, o curso atende às exigências estabelecidas na Dimensão cinco do Instrumento de Avaliação Externa que considera a graduação do corpo de tutores presenciais e a distância como um referencial mínimo de qualidade, sendo indispensável para o credenciamento das IES na modalidade a distância EAD (Instrumento de Avaliação Externa (2014).

Em conformidade com a Resolução CD/FNDE $n^{\circ}$ 26, de 5 de junho de 2009, a maioria dos respondentes possui pós-graduação, atendendo uma das exigências para ter vínculo bolsista como tutor.

Retomando a questão das competências necessárias para as atividades de tutoria, constatou-se que existem peculiaridades na modalidade a distância que requerem do tutor competências específicas que atendam as características dessa modalidade de ensino, sendo necessário que o tutor apresente uma postura diferenciada no que se refere à sua formação. 
CAMPOS (2009) aponta para algumas características necessárias para uma formação voltada para o atendimento das peculiaridades do universo de mediação: a mobilização, a aplicação de recursos e a solução de problemas.

Nessa mesma direção, em sintonia com os apontamentos de CAMPOS (2009), MACHADO; MACHADO (2007) também destacam características que devem fazer parte da formação teórica do tutor em consonância com a formação na prática:

Este necessita entender a estrutura do assunto que ensina, os princípios da sua organização conceitual e os princípios das novas idéias produtoras de conhecimento na área. Sua formação teórica sobre o âmbito pedagógico-didático deverá ser atualizada com a formação na prática dos espaços tutoriais (p.3)

Acreditando que essas características podem ser trabalhadas na formação continuada dos tutores, buscou-se verificar no item "Você realizou formação específica em EAD?" se os tutores possuem uma formação específica para o Ensino a Distância. Assim, 75,8\% dos tutores respondentes disseram que sim, conforme consta na tabela 8:

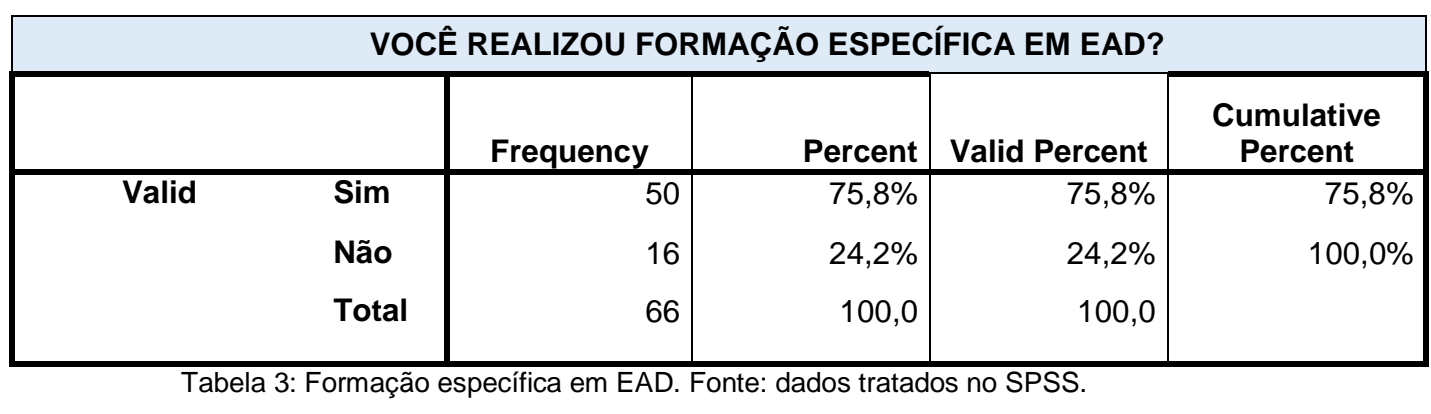

A questão abriu um espaço para que os respondentes que sinalizaram possuir formação específica em EAD identificassem o curso realizado, embora seja importante destacar que esse espaço não era um campo obrigatório no questionário, mas que foi proposto com o objetivo de complementar a compreensão dos resultados desta questão.

Nesse sentido, considerando os 34 tutores que comentaram esse item, foi possível verificar que o curso de especialização em Planejamento, Implementação e Gestão da Educação a Distância, oferecido pela UFF (Universidade Federal Fluminense) foi o mais recorrente nas respostas, seguido pelo curso de extensão de Formação de Tutores oferecido pelo próprio CEDERJ, e dos cursos em 
andamento e não especificados pelos tutores respondentes, como pode ser visto na tabela 9 correspondente aos resultados dos comentários das respostas dos tutores sobre a questão "Você realizou formação específica em EAD?":

\begin{tabular}{|c|c|}
\hline \multicolumn{2}{|l|}{ TABELA - FORMAÇÃO ESPECÍFICA DOS TUTORES } \\
\hline Apenas na pós-graduação & 1 \\
\hline Conclui um curso específico sobre EAD na Faculdade Redentor & 1 \\
\hline Concluindo o TCC de pós-graduação em EAD. & 1 \\
\hline Cursei a Especialização PIGEAD pela UFF. & 1 \\
\hline Curso de extensão oferecido pelo Cederj & 1 \\
\hline Curso de Formação de Tutores oferecido pelo próprio CEDERJ & 1 \\
\hline Curso de tutoria & 1 \\
\hline Cursos de extensão & 1 \\
\hline Cursos do CEDERJ & 1 \\
\hline Design instrucional & 1 \\
\hline Em etapa de conclusão do PIGEAD, além da capacitação desenvolvida pelo Cederj & 1 \\
\hline Especialização em EAD & 1 \\
\hline Especialização em Gestão e Implementação em EAD e outros complementares a EAD & 1 \\
\hline Especialização específica, e cursos de extensão & 1 \\
\hline Especializações citadas na questão 4 & 1 \\
\hline $\begin{array}{l}\text { Estou cursando o PIGEAD da UFF desde out/2014. Antes apenas pequenas orientações sobre a Plataforma e/ou a } \\
\text { disciplina, Algumas delas já com o curso em andamento. }\end{array}$ & 1 \\
\hline Extensão em EAD & 1 \\
\hline Fiz apenas um treinamento quando do início das atividades no CEDERJ. Treinamento de um dia. & 1 \\
\hline Foi o curso mais presencial em toda minha trajetória acadêmica & 1 \\
\hline Formação de tutores do Cederj & 1 \\
\hline Não foi oferecida formação específica em EaD. & 1 \\
\hline Participei do treinamento oferecido pelo CEDERJ aos tutores. & 1 \\
\hline PIGEAD- Planejamento, Implementação e Gestão da Educação à Distância. & 4 \\
\hline Pós em Gestão e Implementação da EAD & 1 \\
\hline Pós-Graduação em Ensino a Distância & 1 \\
\hline Pós-graduação na UFF & 1 \\
\hline Realizei curso de extensão na área. Pretendo fazer uma pós-graduação na área. & 1 \\
\hline $\begin{array}{l}\text { Sim "me referindo à cursos específicos para a EaD, embora o tema não tenha sido abordado na graduação, } \\
\text { especialização..." }\end{array}$ & 1 \\
\hline Somente curso proposto pelo Cederj & 1 \\
\hline Sou pós graduada em controladoria e finanças numa universidade EAD. & 1 \\
\hline Total & 33 \\
\hline
\end{tabular}

Tabela 4: Cursos de extensão e/ou especialização realizados pelos tutores. Fonte: dados tratados no SPSS.

O curso de especialização em Planejamento, Gestão e Implementação da Educação a Distância é oferecido gratuitamente pelo LANTE - Laboratório de 
Novas Tecnologias de Ensino desde 2008, e possui vinculo direto com o Instituto de Matemática da Universidade Federal Fluminense (UFF). Segundo informações do portal do LANTE, o curso surgiu com o objetivo de apoiar a Gestão Acadêmica do Curso de Licenciatura em Matemática a Distância implementado em colaboração com o CEDERJ e a UAB.

Sobre o curso de Formação de Tutores oferecido pelo próprio CEDERJ intitulado "Curso de Qualificação Profissional em Tutoria”, segundo informações do portal do CEDERJ, o objetivo é ofertar formação técnico-profissional na modalidade a distância, não só para os tutores do CEDERJ, como também, para todos os tutores que já atuam nesta modalidade de ensino, além de professores de escolas públicas que desejam atuar na área. O curso de extensão tem a duração de 150 horas,

Dessa maneira, percebe-se a preocupação do CEDERJ em atender as exigências estabelecidas pelo Instrumento de Avaliação Institucional Externa (2014) buscando garantir a formação continuada dos tutores.

Com relação à pergunta "Há quanto tempo você trabalha como tutor?", percebe-se na tabela abaixo que o maior percentual das respostas se concentra entre 4 a 8 anos (40,9\%), seguido pelos percentuais até dois anos $(28,8 \%)$ e de 2 a 4 anos $(18,2 \%)$, que se encaixam no período de duração das bolsas concedidas aos tutores, que, segundo o último edital do concurso para tutores do CEDERJ (Edital para seleção de Tutores para os cursos de graduação do Consórcio CEDERJ, 2015), tem a duração de dois anos, prorrogáveis por mais dois.

\begin{tabular}{|c|c|c|c|c|c|}
\hline \multicolumn{6}{|c|}{ HÁ QUANTO TEMPO VOCÊ TRABALHA COMO TUTOR (A)? } \\
\hline & & Frequency & Percent & Valid Percent & $\begin{array}{l}\text { Cumulative } \\
\text { Percent }\end{array}$ \\
\hline Valid & até 2 anos & 19 & 28,8 & $28,8 \&$ & $28,8 \%$ \\
\hline & de 2 a 4 anos & 12 & 18,2 & $18,2 \%$ & $47,0 \%$ \\
\hline & de 4 a 8 anos & 27 & 40,9 & $40,9 \%$ & $87,9 \%$ \\
\hline & mais de 8 anos & 8 & 12,1 & $12,1 \%$ & $100,0 \%$ \\
\hline & Total & 66 & 100,0 & 100,0 & \\
\hline
\end{tabular}

Tabela 5: Tempo de trabalho na tutoria em EAD. Fonte: dados tratados no SPSS.

A concentração de tutores com 4 a 8 anos de trabalho na tutoria possivelmente deve-se à implantação do sistema UAB, instituído em 2006, que 
promoveu a difusão da EAD no território nacional por meio de convênios firmados com instituições públicas de Ensino Superior.

Entretanto, a difusão da EAD caminha lado a lado com a precarização do trabalho do tutor, sem garantir o reconhecimento profissional, o pagamento de uma remuneração justa e um vínculo empregatício adequado para os tutores bolsistas, assim como também, sem apresentar condições estruturais de trabalho para eles, ocasionando a necessidade do tutor desempenhar outras atividades que complementem o seu orçamento.

A docência, distribuída em diferentes papéis, como o de professor e o de tutor (a distância e presencial), está definida em resoluções que enquadram esses profissionais como bolsistas que sequer têm direito a uma declaração do trabalho que realizam como professores, devido à possível consolidação de vínculos empregatícios não desejados. Tal precarização do trabalho docente se desdobra, na prática, entre outras coisas, por meio da baixa remuneração, que exclui profissionais qualificados, e da falta de reconhecimento profissional. Complementarmente, configura-se a implantação de uma política pública nacional, que define o papel dos tutores como não docentes (LAPA; PRETTO, 2010, p. 1).

Nessa mesma direção, sobre o desempenho de outras atividades profissionais concomitantemente à tutoria, 92,4\% dos tutores respondentes sinalizaram possuir outra atividade profissional além da tutoria no CEDERJ/UFRRJ, conforme os dados da tabela 11, reforçando a ideia de que a baixa remuneração fortalece a precarização do trabalho do tutor, ocasionando o excesso de atividades profissionais que são exercidas ao mesmo tempo que a tutoria, subentendendo-se que o trabalho desenvolvido por eles não demanda esforço e pode ser administrado concomitantemente a outras funções.

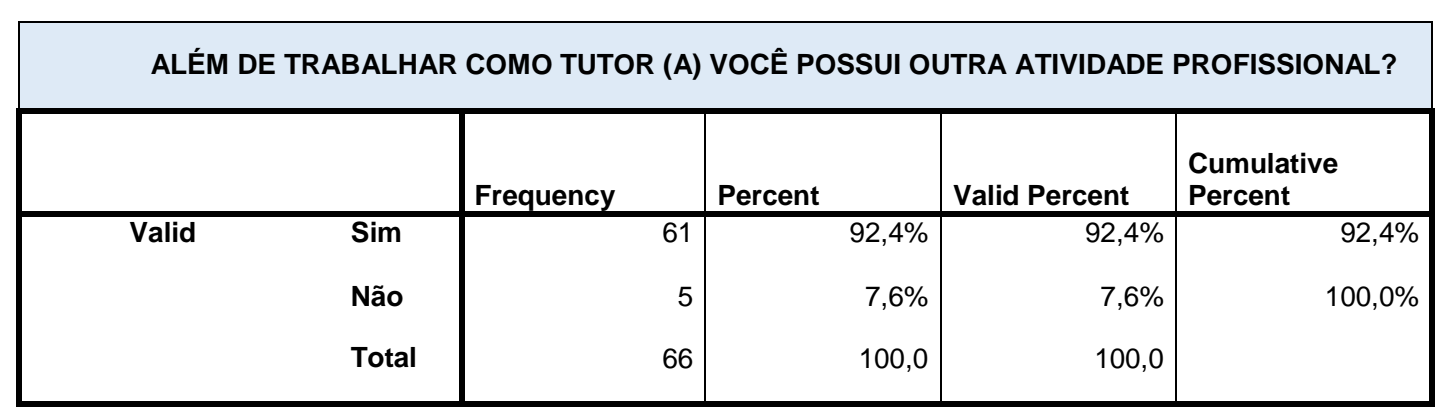

Tabela 6: Outras atividades profissionais exercidas. FONTE: dados tratados no SPSS. 
Nesse contexto, MILL et. al. (2008) destacam que:

Dessa forma, a tutoria é uma categoria profissional ainda sem regulamentação, bastante explorados, sem vínculo empregatício e sem condições estruturais de trabalho. Há um engodo em perdurar no discurso do mercado, que argumenta que a tutoria é um trabalho com flexibilidade espaço-temporal, que pode ser executado concomitantemente a outras atividades profissionais e que não demanda tanto esforço do trabalhador. (p. 68).

É preciso ter atenção com relação ao discurso da flexibilidade espaçotemporal do trabalho de tutoria destacado MILL et. al. (2008), uma vez que ele acaba camuflando a sobrecarga de trabalho e, consequentemente, acaba reforçando ainda mais o processo de precarização do trabalho do tutor.

Sobre essa questão, MENDES (2013) faz uma reflexão referente a preocupação com a flexibilidade do trabalho na EaD:

Isto porque um dos principais argumentos usados na defesa do EAD é o da criação de cursos de graduação a pessoas que não dispõem de tempo nos períodos em que são ofertados os cursos presenciais. Assim, se cada estudante poderá buscar o auxílio do professor nos momentos em que tiver disponibilidade para estudar, qual será o tempo e o espaço de trabalho desse docente? Como o uso das tecnologias interativas pode ser feito a qualquer momento e em qualquer lugar, esse professor poderá perder totalmente a noção do que seria o tempo de trabalho (formal) e de lazer, tornando-se, assim, o trabalho demanda permanente na sua vida (p. 10).

Nesse sentido, podemos inferir que a questão da flexibilidade espaçotemporal, aliada a sobrecarga de trabalho são aspectos presentes nas características do perfil dos tutores respondentes, uma vez que a grande maioria exerce outras atividades profissionais, além da tutoria.

\subsection{2 \\ Descrição e análise quantitativa: Características relacionadas à experiência dos tutores}

No segundo bloco, objetiva-se identificar as práticas predominantes no trabalho de tutoria e a relação do tutor com a função que exerce no contexto em que o seu trabalho está inserido.

A primeira questão deste bloco do questionário teve como objetivo identificar o grau de conhecimento pedagógico do tutor em relação ao curso de 
administração, partindo do conhecimento que ele possui do seu projeto políticopedagógico.

Apesar das condições expostas no primeiro bloco evidenciarem a precarização da atividade de tutoria, o fato de o tutor conhecer o projeto políticopedagógico do seu curso sugere uma disposição subjetiva frente ao seu envolvimento com a proposta e objetivos pedagógicos traçados pelo curso, demonstrando que existe uma relação de trabalho que transcende as barreiras impostas pelas dificuldades ocasionadas pela precarização da sua função na $\mathrm{EaD}$.

Conforme podemos perceber na tabela 12 , o perfil dos tutores respondentes é delineado por uma relação bem próxima entre os tutores e o projeto político-pedagógico do curso, uma vez que $67,7 \%$ dos tutores responderam ter conhecimento do projeto político-pedagógico.

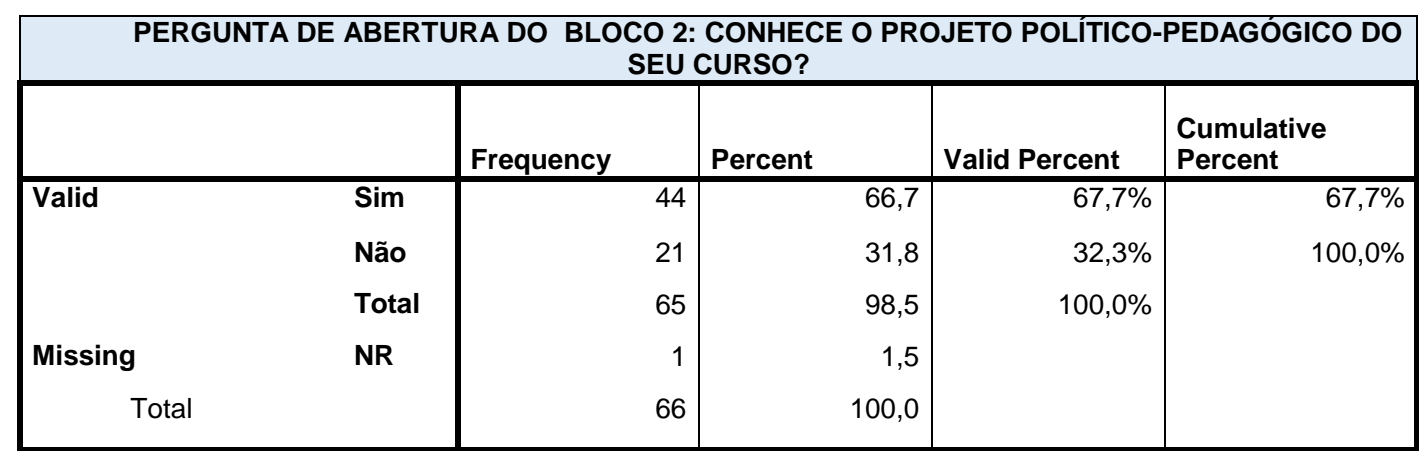

Tabela 7: Relação do tutor com o Projeto Político-Pedagógico do curso. Fonte: Dados tratados no SPSS.

É importante fazer menção ao percentual dos respondentes que não conhecem o projeto político-pedagógico do curso (31,8\%), uma vez que essa questão se constitui numa das competências que devem fazer parte da sua identidade profissional, pois é por meio do projeto político-pedagógico que se conhece a estrutura do curso, neste caso, "o contato com o aluno começa pelo conhecimento da estrutura do curso" (MACHADO; MACHADO, 2004, p. 11).

Buscando identificar as práticas predominantes no trabalho dos tutores que participaram do questionário, levantamos as questões de acordo com as experiências de cada tutor frente ao desenvolvimento de seu trabalho com os alunos considerando uma escala de relevância que variava entre "nunca, poucas vezes, muitas vezes e sempre". 
As questões listadas no bloco de perguntas apresentadas no gráfico 4 foram pensadas a partir das reflexões feitas no capítulo 3 deste estudo, referentes às competências necessárias para o exercício da função do tutor.

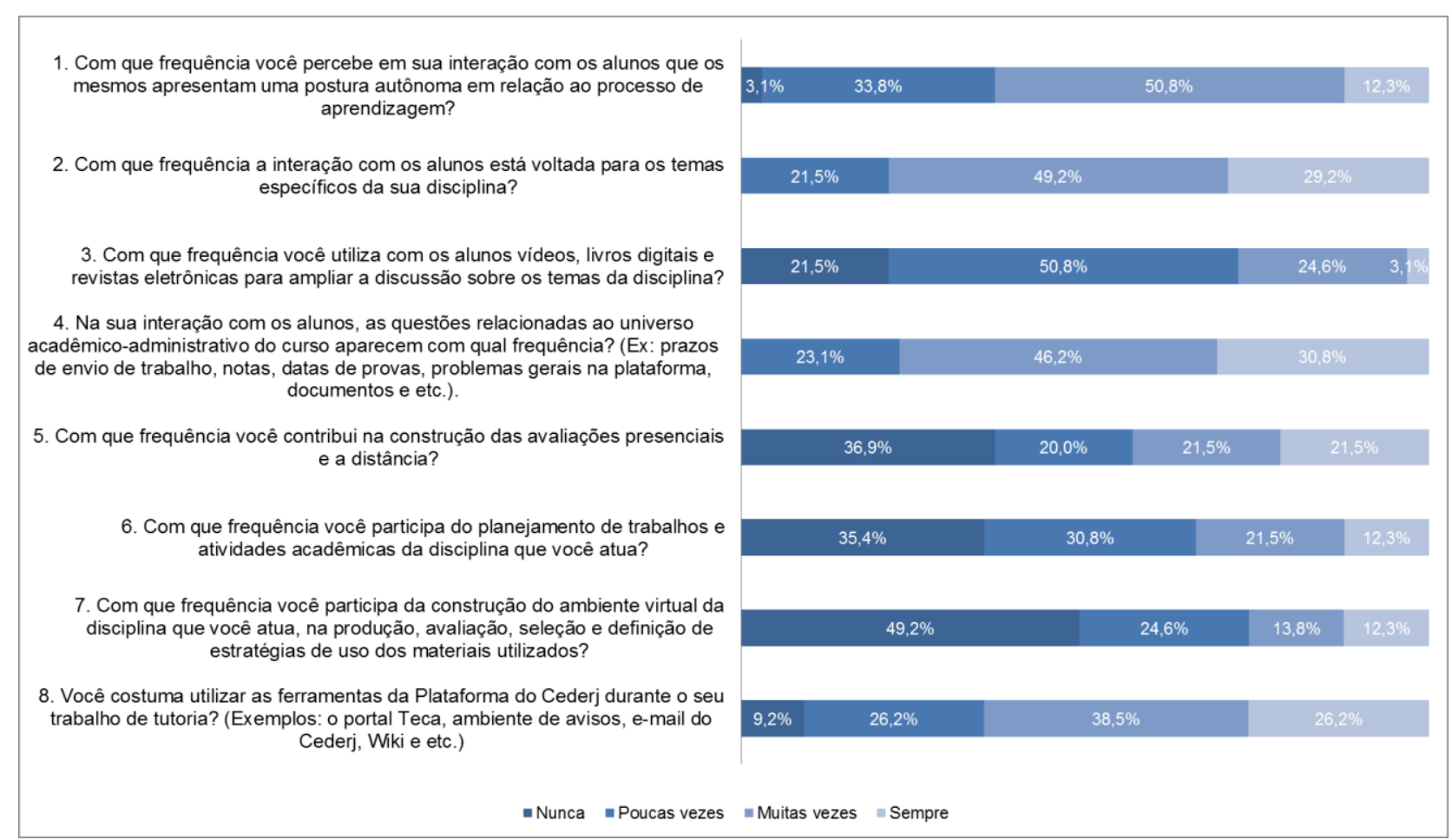

Gráfico 4: Sobre a interação com os alunos. Fonte: dados tratados no SPSS.

Com relação à pergunta 1: "Com que frequência você percebe em sua interação com os alunos que os mesmos apresentam uma postura autônoma em relação ao processo de aprendizagem?" esta, foi pensada a partir dos estudos de MILL et. al. (2008), considerando a necessidade de o tutor acompanhar os alunos em seus estudos, trabalhando a autonomia.

A partir dos resultados da pergunta 1 (um), 50,8\% dos respondentes sinalizaram perceber "muitas vezes" durante a interação com os alunos uma postura autônoma em relação ao processo de aprendizagem, somados ao percentual de "sempre", alcançamos um percentual de $63,1 \%$ dos respondentes.

Entretanto, os resultados encontrados nas respostas correspondentes à "nunca" (3,1\%) e "poucas vezes" (33,8\%) chamam a atenção para uma necessidade de refletirmos sobre o desenvolvimento de práticas que favoreçam o desenvolvimento da autonomia dos alunos, uma vez que o aprendizado autônomo e flexível é uma das características da Educação a Distância (CAMPOS, 2000). 
A questão (dois) 2: “Com que frequência a interação com os alunos está voltada para os temas específicos da sua disciplina?" foi construída com o objetivo de compreender se as ações dos tutores estão voltadas para as questões de ordem burocrática como datas das provas, notas, entre outros, reforçando a ideia de que o tutor atua apenas como informante das questões administrativas do curso, limitando a função do tutor a um mero "porta-voz" dos professores e coordenadores de curso. (VILARINHO; CABANAS, 2008).

Nesse sentido, em resposta a essa questão, alcançamos os seguintes percentuais: "poucas vezes" (21,5\%), "muitas vezes" (49,2\%) e "sempre" (29 $2 \%$ ). Os resultados encontrados apontam para um perfil de tutores que não atuam apenas com questões burocráticas do curso, mas exercem uma função voltada para os temas propostos pela disciplina que atuam. Esse resultado vai de encontro às competências apontadas por MENDES (2013), MILL et. al. (2008), SILVA (2008) e MACHADO; MACHADO (2004) que destacam a necessidade do acompanhamento dos alunos em seus estudos, através do conhecimento e diálogo sobre os assuntos relacionados à matéria e área profissional em foco.

Entretanto, buscando complementar o entendimento sobre as características do tutor, cabe relacionarmos esses resultados com a questão 4 (dois) , citada anteriormente: "Na sua interação com os alunos, as questões relacionadas ao universo acadêmico-administrativo do curso aparecem com qual frequência? (Ex: prazos de envio de trabalho, notas, datas de provas, problemas gerais na plataforma, documentos etc.)". Essa questão aponta para um percentual expressivo sobre a presença de características de ordem burocrática e administrativa nos resultados obtidos dos tutores respondentes, com 46,2\% de respostas para "muitas vezes" e 30,8\% de respostas para "sempre".

Esse resultado aponta para o trabalho de tutoria que se divide entre ações docentes, uma vez que os tutores interagem com os alunos sobre os temas da disciplina, juntamente com as ações de ordem burocrática do curso, atendendo às demandas dos alunos.

Retomando a ordem do segundo bloco de questões, na pergunta 3 (três): "Com que frequência você utiliza com os alunos vídeos, livros digitais e revistas eletrônicas para ampliar a discussão sobre os temas da disciplina?” buscou-se verificar se os tutores fazem uso de ferramentas comunicacionais com os alunos, uma vez que essas ferramentas são fundamentais para o processo de aprendizagem 
dos alunos e da "manutenção de um estado contínuo de comunicação" (CAMPOS; AMARAL, 2011, p. 10).

Os percentuais "nunca" $(21,5 \%)$ e "poucas vezes" $(50,8 \%)$ chamam a atenção para a pouca utilização destes materiais pelos tutores, uma vez que utilizar e dominar as múltiplas redes articulatórias de conexões e significados são características necessárias para a função, o que segundo SILVA (2008), saber lidar com essas múltiplas redes e ferramentas é possuir a competência de permutabilidade-potencialidade.

Com relação à pergunta 5 (cinco): "Com que frequência você contribui na construção das avaliações presenciais e a distância"? Percebe-se que os percentuais "nunca" (36,9\%) e "poucas vezes" $(20,0 \%)$ se somados, ultrapassam os percentuais "muitas vezes" (21,5\%) e "sempre" (21,5\%). Nesse sentido, os respondentes apontam para o distanciamento do processo de construção das avaliações dos alunos.

As respostas dos tutores para a pergunta 6 (seis): "Com que frequência você participa do planejamento de trabalhos e atividades acadêmicas da disciplina que você atua? também aponta para um percentual que evidencia o distanciamento dos tutores no planejamento de trabalhos e outras atividades acadêmicas da disciplina que eles atuam, uma vez que $35,4 \%$ disseram que nunca participam e $30,8 \%$ disseram que participam poucas vezes. Somando esses percentuais, a grande maioria dos respondentes aponta para um distanciamento dos tutores frente a participação no planejamento das atividades acadêmicas da disciplina em que atuam, uma vez que os percentuais de "muitas vezes" e "sempre", alcançam o percentual de $33,8 \%$ dos respondentes.

Seguindo um resultado similar aos das questões 5 e 6 , as respostas dos tutores para a pergunta 7 (sete): “Com que frequência você participa da construção do ambiente virtual da disciplina que você atua, na produção, avaliação, seleção e definição de estratégias de uso dos materiais utilizados?" também apontam para uma grande maioria de tutores que está distante da participação e construção do ambiente virtual da disciplina, uma vez que 49, $2 \%$ disse que nunca participa e $24,6 \%$ responderam que participam poucas vezes, superando os respondentes que disseram que participam "muitas vezes" $(13,8 \%)$ e sempre $(12,3 \%)$. 
Esse percentual demonstra a não participação da maioria dos tutores respondentes, não só na produção das avaliações, mas também, na seleção e definição de estratégias de uso dos materiais utilizados nas disciplinas em que atuam, caracterizando a falta de autonomia para lidar com o planejamento dos materiais que vão utilizar com os alunos nos ambientes virtuais.

Cabe destacar que as perguntas 5 (cinco), 6 (seis) e 7 (sete) foram construídas tendo como base os estudos de MACHADO; MACHADO (2004) referente ao papel da tutoria no ambiente da Educação a Distância. Segundo os autores, "a habilidade para planejar, acompanhar e avaliar atividades, bem como motivar o aluno para o estudo, também são relevantes" (MACHADO; MACHADO, 2004, p. 7).

Encerrando o segundo bloco de questões sobre as práticas predominantes no trabalho de tutoria apresentamos os resultados da pergunta oito: "Você costuma utilizar as ferramentas da Plataforma do Cederj durante o seu trabalho de tutoria? (Exemplos: o portal Teca, ambiente de avisos, e-mail do CEDERJ, Wiki e etc.)". Nesta questão, encontramos um percentual maior nas respostas referentes a "muitas vezes" (38,5\%) e "sempre" (26,2\%), frente aos percentuais de baixa frequência nas respostas "nunca" (9,2\%) e "poucas vezes" (26,2\%).

Sobre os resultados encontrados nesta pergunta percebe-se que os tutores procuram seguir as orientações do CEDERJ com relação à utilização das ferramentas da plataforma do curso, uma vez que a grande maioria dos tutores utilizam as ferramentas.

É importante comentar o resultado dos 9,2\% que nunca utilizaram, uma vez que partindo da hipótese que sejam tutores presenciais, ou seja, teoricamente poderiam não utilizar por conta de se relacionarem presencialmente com os alunos, o próprio edital do último concurso para tutores do CEDERJ (2015) orienta aos tutores presenciais que utilizem a plataforma para participar da correção das Avaliações a Distância (ADs), conhecer as ferramentas de apoio oferecidas para as disciplinas em que atuam cadastrar, na plataforma, a frequência dos alunos nas sessões de tutoria, entre outros quesitos.

Nesse sentido, trata-se de um resultado que merece ser destacado, tendo em vista que de certa forma, alguns tutores por motivos não relatados, não acessam a plataforma em momento algum, mesmo sendo uma das orientações dos 
últimos editais do processo seletivo para tutores presenciais e a distância do CEDERJ (2015).

Isso sugere a possibilidade de dificuldades encontradas pelos tutores para acessar a plataforma, ou até mesmo, a falta de tempo do tutor para lidar com as atividades extras que ele exerce de maneira a complementar o seu orçamento mensal, conforme vimos no primeiro bloco de questões quando apresentamos os resultados da pergunta referente a outras atividades desenvolvidas pelos tutores além da tutoria e $92,4 \%$ dos tutores respondentes disseram que possuíam outra atividade profissional além da tutoria no CEDERJ.

\subsection{3 \\ Descrição e análise quantitativa: percepções do tutor sobre o lugar que ele ocupa na Educação a Distância}

No terceiro bloco de questões, objetiva-se identificar as percepções do tutor sobre a sua função e sobre o lugar que ele ocupa na Educação a Distância. As questões foram construídas partindo da necessidade de compreendermos a percepção dos tutores sobre a sua identidade, considerando que "para que um tutor exerça sua função a contento, em primeiro lugar ele e as demais pessoas envolvidas no curso devem conhecer bem o seu papel" (NUNES, 2013, p. 1).

Buscando identificar as percepções dos tutores que participaram do questionário, levantamos questões de acordo com as experiências de cada tutor frente ao grau de discordância e concordância considerando uma escala de relevância que variava de "discordo totalmente, discordo parcialmente, concordo parcialmente e concordo totalmente".

Encerrando a análise dos resultados encontrados no terceiro bloco de questões, optou-se pela realização de uma análise fatorial dos resultados encontrados, no sentido de identificar as correlações entre as variáveis nas respostas deste bloco, considerando que os dados coletados apresentaram resultados significativos em relação às resposta das questões centrais deste estudo

A primeira questão do bloco 3 (três) do questionário teve como objetivo identificar o grau de percepção dos tutores em relação à sua percepção sobre a responsabilidade da função que desempenha frente ao desenvolvimento dos alunos, como podemos verificar no gráfico 05 : 


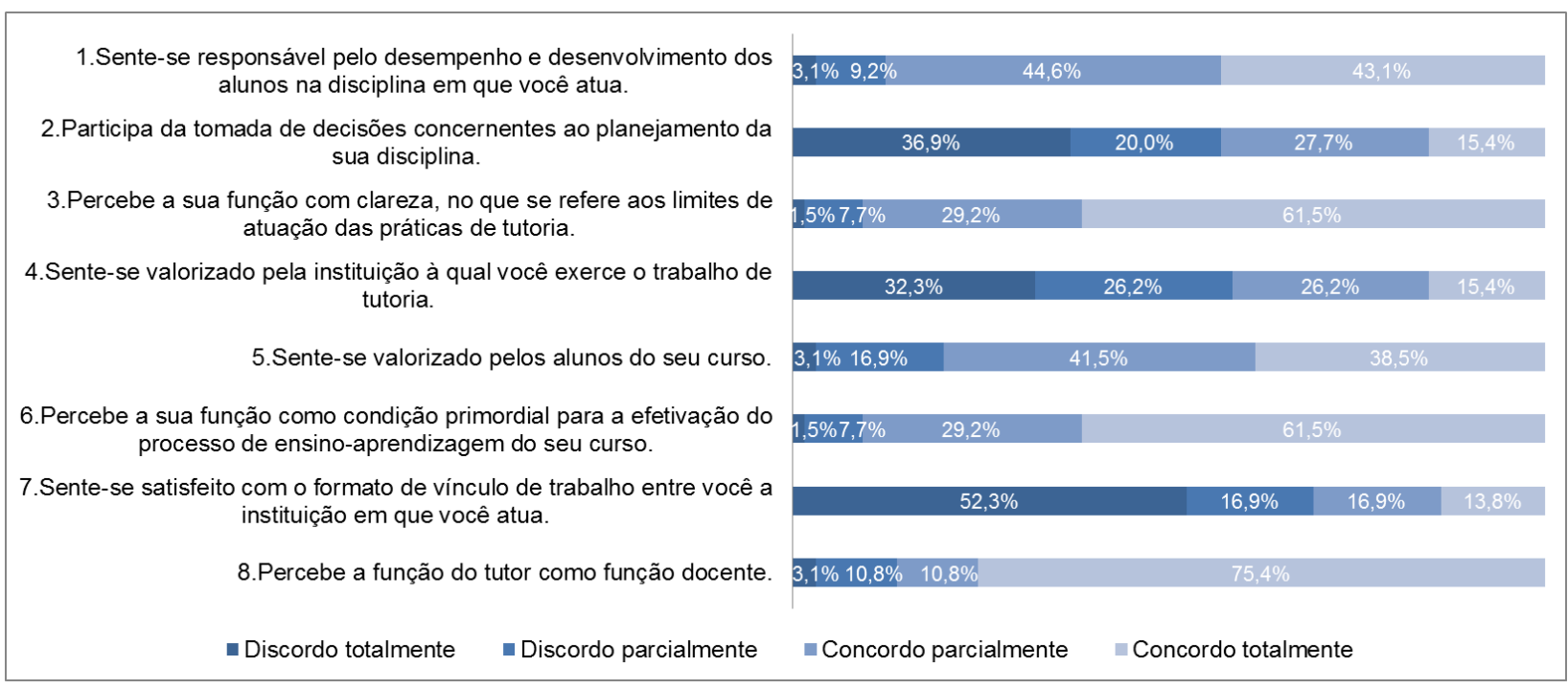

Gráfico 05: Percepções do tutor sobre o lugar que ele ocupa na Educação a Distância. Fonte: SPSS.

Nesse sentido, solicitamos que o tutor indicasse o grau de concordância de acordo com a sua experiência sobre a seguinte afirmação: "Sente-se responsável pelo desempenho e desenvolvimento dos alunos na disciplina em que você atua". Os percentuais apresentaram uma maior frequência nas respostas correspondentes a "concordo plenamente" $(44,6 \%)$ e "concordo totalmente" $(43,1 \%)$, evidenciando um grau de concordância expressivo nesta afirmação, com relação aos percentuais alcançados $(87,7 \%)$.

Entretanto, os percentuais alcançados nas respostas "discordo totalmente" $(3,1 \%)$ e "discordo parcialmente" (9,2\%), ainda que não sejam expressivos, chamam a nossa atenção para a questão do não reconhecimento do próprio tutor em relação a sua importância diante do desempenho e desenvolvimento dos alunos.

Fazendo relação desse resultado com os resultados apresentados no segundo bloco de questões, onde verificamos o distanciamento dos tutores frente à participação no planejamento das atividades acadêmicas da disciplina em que atuam, pode-se levantar a hipótese de que esse distanciamento se constitui num dos fatores que interferem nos resultados alcançados neste item do bloco três.

A pouca participação dos tutores no processo de planejamento das disciplinas que atuam, fortalece e caracteriza a falta de autonomia do tutor em lidar com o planejamento dos materiais e atividades da disciplina que eles mesmos vão utilizar com os alunos ao longo do curso, ocasionando a não 
percepção dos tutores como responsáveis pelo desempenho e desenvolvimento dos alunos na disciplina que eles atuam.

Seguindo essa mesma ideia sobre a falta de autonomia do tutor com relação às disciplinas que atuam, a segunda afirmação deste bloco de questões, também apresenta um percentual que caracteriza ainda mais o distanciamento dos tutores com relação ao planejamento da disciplina. A partir da afirmação "Participa da tomada de decisões concernentes ao planejamento da sua disciplina" os tutores respondentes, em sua maioria, discordaram da afirmação, demonstrando que não participam ou pouco participam da tomada de decisões sobre o planejamento da disciplina que atuam. Foram 36,9\% que responderam "discordo totalmente" e 20,7\% que assinalaram a opção "discordo parcialmente".

Mesmo diante dos resultados dos tutores que sinalizaram a participação na tomada de decisão do planejamento das disciplinas que atuam com "concordo parcialmente" $(27,7 \%)$ e concordo plenamente $(15,4 \%)$, representando $43,1 \%$ dos tutores respondentes, a partir das respostas dos que discordaram e dos resultados apresentados no bloco anterior sobre a participação no planejamento, podemos verificar que essa questão é um fator que precisa ser considerado na construção do perfil dos tutores do curso de Administração do CEDERJ/UFRRJ, de modo que os resultados sugerem a falta de autonomia e a não percepção dos tutores como responsáveis pelo desempenho e desenvolvimento dos alunos, uma vez que planejar, acompanhar e avaliar atividades, são características relevantes que devem fazer parte da função do tutor (MACHADO; MACHADO, 2004).

Com relação à afirmativa "Percebe a sua função com clareza, no que se refere aos limites de atuação das práticas de tutoria”, os tutores respondentes, em sua maioria, concordaram com a afirmação, sendo $29,2 \%$ que concordaram parcialmente e $61,5 \%$ que concordaram totalmente.

É importante destacar o percentual dos respondentes que discordou da afirmação sobre a percepção deles com relação à sua função e aos limites de atuação das suas práticas, mesmo não sendo um percentual expressivo, pois 1,5\% discordou totalmente e $7,7 \%$ discordou parcialmente, chama atenção por se tratar de um aspecto relevante para o desempenho da função de tutoria, de modo que para desenvolvermos bem uma função, precisamos conhecer os limites de atuação que cercam a função a ser desempenhada, principalmente, quando se trata do 
tutor, "sendo este entendido como um dos principais agentes da mediação pedagógica na modalidade a distância” (CASTRO, 2013, p.23).

Sobre a afirmativa "Sente-se valorizado pela instituição à qual você exerce o trabalho de tutoria", os percentuais de maior frequência se concentram nas respostas "discordo totalmente" com 32,3\% e "discordo parcialmente" com $26,2 \%$, alcançando juntas a maioria dos tutores respondentes. Esse percentual evidencia o sentimento de desvalorização dos tutores com relação ao trabalho desenvolvido por eles, que não se percebem valorizados pela instituição à qual estão vinculados.

Os percentuais das respostas da opção "concordo parcialmente" $(26,2 \%)$ também abre uma lacuna no que se refere ao termo "parcialmente", uma vez que podemos levantar a hipótese de que concordar parcialmente com a questão de sentir-se valorizado pela instituição à qual os respondentes exercem o trabalho de tutoria, sugere ressalvas por parte dos respondentes, transparecendo que mesmo concordando existe algum fator que deixa o sentimento de valorização incompleto, pleno. Diferentemente disso, a opção "concordo completamente", não deixa dúvidas da percepção de valorização dos $15,4 \%$ respondentes desta opção.

Neste sentido, considerando a descrição dos resultados de concordância desta afirmativa, verifica-se que o perfil dos tutores respondentes é delineado por uma percepção de não valorização pela instituição em que exercem a tutoria.

Entretanto, como vimos anteriormente na descrição do primeiro bloco de questões, o não pagamento de uma remuneração justa e a ausência de vínculo empregatício adequado para os tutores bolsistas são componentes que se destacam dentro do processo de precarização do trabalho do tutor (LAPA; PRETTO, 2010) e, certamente, devem pesar sobre a percepção com relação a não valorização pela instituição em que atuam, pois “os vínculos precários de trabalho e as condições inadequadas de exercício da docência produzem nos tutores a sensação de despreparo, insegurança, ansiedade e baixa autoestima" (MENDES, 2013, p. 19).

Em resposta à afirmação "Sente-se valorizado pelos alunos do seu curso", as opções que concentraram os maiores percentuais foram as de concordância: "concordo parcialmente" com 41,5\% e "concordo plenamente" com 38,5\% dos tutores respondentes. Muito embora, assim como foi abordado na questão anterior, é preciso ressaltar que o termo parcialmente pode sugerir ressalvas por parte dos 
respondentes, ou seja, mesmo concordando com a afirmação, existe algum fator que o deixa parcialmente de acordo.

Dessa maneira, os percentuais que apontam para a desvalorização dos tutores por parte dos alunos, não podem ser desconsiderados em nossa análise. Os percentuais de $3,1 \%$ de respondentes que discordou totalmente e de $16,9 \%$ que discordou parcialmente representam um fator que merece atenção, uma vez que se trata da relação entre alunos e tutores e deve servir de indicador para repensarmos essa relação.

É importante destacar que a interação entre tutores e alunos se constitui num dos principais elementos do processo de aprendizagem na modalidade a distância, realizado por meio das ferramentas comunicacionais, buscando garantir que a interação com os alunos não seja prejudicada. "Nesse âmbito a interação entre professor e aluno realizada pelos meios de comunicação informacionais ganha importância para que a mediação didático-pedagógica ocorra de forma efetiva" (CAMPOS; AMARAL, 2011, p.49).

$\mathrm{Na}$ questão seguinte, os tutores respondentes indicaram que percebem a sua função como condição primordial para a efetivação do processo de ensinoaprendizagem do seu curso. O resultado do item "concordo totalmente" $61,5 \%$ corresponde à maioria dos respondentes, seguido de 29,2\% do resultado dos respondentes da opção "concordo parcialmente". Identificou-se assim um perfil que percebe a importância da sua função para a efetivação do processo de aprendizagem do seu curso, uma vez que "devemos entender a tutoria como central no processo de ensino à distância, como condição sine qua non para que o ensino se efetive" (TONNETTI, 2012, p.12).

Sobre a satisfação dos tutores com o formato do vínculo de trabalho com a instituição em que atuam, os resultados apontam para um número bem expressivo de discordância dos tutores respondentes. O resultado da opção "discordo totalmente" é de 52,3\% seguido do resultado da opção "discordo parcialmente" com 16,9\% das respostas. Esse resultado evidencia o desconforto dos tutores com o formato do vínculo de trabalho que eles possuem, "além do fato de o tutor ser um bolsista, sem um vínculo mais formal de trabalho, também não há muitas garantias nos pagamentos das bolsas, que atrasam e não têm data certa de depósito" (MENDES, 2013, p. 15). 
Com relação aos resultados "concordo totalmente" 16,9\% e "concordo parcialmente" $13,8 \%$, é importante destacar que os resultados podem sugerir a ideia de que o trabalho do tutor com vínculo de bolsista é entendido pelo próprio tutor como "um incremento ao orçamento mensal" (MENDES 2013, p. 17), de modo que o tutor naturaliza essa relação de trabalho por conta de exercer outras atividades além da tutoria. Esse fator se encaixa com o perfil dos tutores respondentes deste estudo, uma vez que vimos no primeiro bloco de questões que $92,4 \%$ dos tutores respondentes desempenham outras atividades profissionais concomitantemente à tutoria no CEDERJ.

O terceiro bloco de questões referiam-se às percepções do tutor sobre o lugar que ele ocupa na Educação a Distância, buscando compreender se a função dele é percebida como função docente. Nesse sentido, em resposta ao item "Percebe a função do tutor como função docente" os tutores em sua maioria, $75,4 \%$, disseram concordar totalmente com a afirmação, seguido de 10,8\% dos tutores respondentes que optaram por concordar parcialmente.

Com relação aos percentuais de "discordo totalmente" $(3,1 \%)$ e "discordo parcialmente" $(10,8 \%)$, vale destacar que esse resultado pode sugerir a dificuldade de percepção do próprio tutor sobre o papel que ele ocupa na EAD. Vimos nos resultados sobre a questão "Percebe a sua função com clareza, no que se refere aos limites de atuação das práticas de tutoria" que 9,2\% (soma dos resultados dos resultados de "discordo totalmente" e "discordo parcialmente") dos respondentes não tem clareza quanto aos limites de sua atuação, o que sugere também, uma certa dificuldade na percepção da própria função como docência.

No recorte dessas concepções fica evidente a indefinição quanto ao tutor ser ou não um professor e aos limites e abrangência de sua ação. As indefinições em relação a quem é este personagem acabam por fragilizar e descaracterizar a EAD. Por outro lado, reconhecemos o quanto é recente a preocupação em definir esse sujeito, a partir de um olhar mais cuidadoso e com base em pesquisas nessa área (CABANAS e VILARINHO, 2007, p.8).

Aliado a isso, temos também a questão e os resultados sobre a desvalorização do seu papel como mais um fator que pode ter interferido na opção dos tutores respondentes em sinalizar esse percentual de discordância em relação a perceber a sua função como função docente. 


\subsubsection{1}

\section{As percepções dos tutores sobre o lugar que eles ocupam na Educação a Distância à luz da análise fatorial}

A ausência de um vínculo empregatício que garanta os direitos trabalhistas para os tutores bolsistas se constitui num dos elementos principais dentro do processo de precarização do trabalho do tutor (LAPA; PRETTO, 2010), contribuindo para que a percepção dessa função esteja pautada no sentimento de desvalorização, ocasionado pelo frágil vínculo de trabalho (MENDES, 2013).

Os aspectos mais frequentes nos resultados encontrados na análise frequencial no terceiro bloco de questões relacionam-se à desvalorização do papel do tutor, tanto pela instituição em que trabalham, como também pelo frágil vínculo trabalhista ao qual são submetidos e respondem de forma significativa às questões deste estudo.

Nesse contexto, optou-se pela realização de uma análise fatorial exploratória deste bloco de questões, com o auxílio do software SPSS, procurando "explorar a relação entre um conjunto de variáveis, identificando padrões de correlação" FILHO; JÚNIOR (2010, p. 165), definindo as dimensões latentes e comuns entre as respostas deste bloco, de modo a encontrar um conjunto de fatores que explique com mais clareza o que as variáveis deste bloco de questões partilham em comum.

Na concepção de FILHO; JÚNIOR (2010), “a principal função das diferentes técnicas de análise fatorial é reduzir uma grande quantidade de variáveis observadas em um número menor de fatores" (p.163).

Para COSTA (2006), a análise fatorial é uma técnica multivariada que consegue "acomodar múltiplas variáveis em uma tentativa de compreender as relações complexas não possíveis com métodos univariados e bivariados” (p.23).

Ainda sobre a definição de análise fatorial COSTA (2006) destaca que:

Análise fatorial é um nome genérico dado a uma classe de métodos estatísticos multivariados cujo propósito principal é definir a estrutura subjacente em uma matriz de dados. Em termos gerais, a análise fatorial aborda o problema de analisar a estrutura das inter-relações (correlações) entre um grande número de variáveis (por exemplo, escores de testes, itens de testes, respostas de questionários), definindo um conjunto de dimensões latentes comuns, chamados fatores (p. 22). 
Dessa maneira, buscou-se definir um conjunto dos fatores comuns entre as variáveis deste bloco de questões, a partir dos fatores que não se manifestaram claramente, ou seja, ficaram subjacentes na análise frequencial realizada.

Considerando as etapas do processo de análise fatorial, apresentamos os resultados encontrados na análise do terceiro bloco de questões deste estudo, partindo de algumas estatísticas-chaves que fazem parte do processo de análise fatorial na concepção de COSTA (2006):

- A Matriz de correlação: o triângulo inferior da matriz exibe as correlações simples, $\mathrm{r}$, entre todos os pares possíveis de variáveis incluídas na análise. Os elementos da diagonal, que são todos iguais a 1, em geral são omitidos;

- Comunialidade: porção da variância que uma variável compartilha com todas as outras variáveis consideradas. É também a proporção de variância explicada pelos fatores comuns;

- Autovalor: representa a variância total explicada por cada fator;

- Matriz de fatores ou matriz principal: contém as cargas fatoriais de todas as variáveis em todos os fatores extraídos;

- Scree plot: gráfico dos autovalores versus número de fatores por ordem de extração (p. 27-28).

As variáveis são simultaneamente consideradas nas técnicas de estatísticas-chaves elencadas e partem da visão de interdependência onde todas elas se relacionam uma com as outras, "empregando ainda o conceito da variável estatística, a composição linear de variáveis" (COSTA, 2006, p. 23).

Ao realizar as correlações simples entre todos os pares possíveis de variáveis incluídas na análise deste bloco, percebe-se que os resultados encontrados na matriz de correlação da tabela 13 apontam que o coeficiente de correlação entre os resultados das questões analisadas indica um grau de maior associação entre as seguintes variáveis:

a) Sente-se valorizado pela instituição à qual você exerce o trabalho de tutoria,

b) Sente-se valorizado pelos alunos do seu curso;

c) Sente-se satisfeito com o formato de vínculo de trabalho entre você a instituição em que você atua e

d) Percebe a sua função como condição primordial para a efetivação do processo de ensino-aprendizagem do seu curso. 


\begin{tabular}{|c|c|c|c|c|c|c|c|c|}
\hline 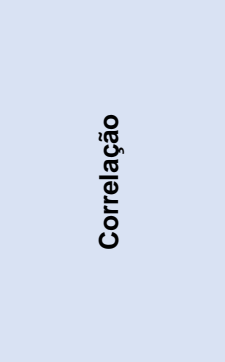 & 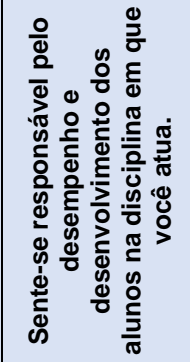 & 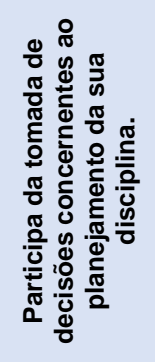 & 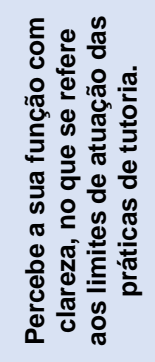 & 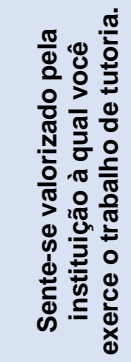 & 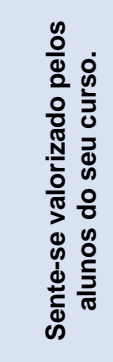 & 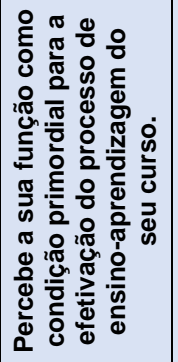 & 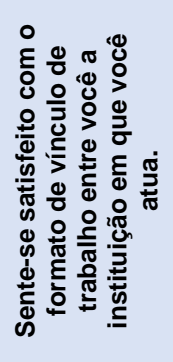 & 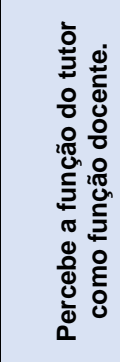 \\
\hline $\begin{array}{l}\text { Sente-se } \\
\text { responsável } \\
\text { pelo } \\
\text { desempenho e } \\
\text { desenvolvimento } \\
\text { dos alunos na } \\
\text { disciplina em } \\
\text { que você atua. }\end{array}$ & 1,000 & ,169 & ,251 & 297 & ,359 & ,372 & ,373 & ,216 \\
\hline $\begin{array}{l}\text { Participa da } \\
\text { tomada de } \\
\text { decisões } \\
\text { concernentes ao } \\
\text { planejamento da } \\
\text { sua disciplina. }\end{array}$ & , 169 & 1,000 & ,276 & ,399 & ,084 & 295 & ,327 & ,153 \\
\hline $\begin{array}{l}\text { Percebe a sua } \\
\text { função com } \\
\text { clareza, no que } \\
\text { se refere aos } \\
\text { limites de } \\
\text { atuação das } \\
\text { práticas de } \\
\text { tutoria. }\end{array}$ & ,251 & 276 & 1,000 & ,396 & 276 & ,438 & ,357 & 255 \\
\hline $\begin{array}{l}\text { Sente-se } \\
\text { valorizado pela } \\
\text { instituição à qual } \\
\text { você exerce o } \\
\text { trabalho de } \\
\text { tutoria. }\end{array}$ & ,297 & ,399 & ,396 & 1,000 & ,402 & ,202 & ,650 & ,227 \\
\hline $\begin{array}{l}\text { Sente-se } \\
\text { valorizado pelos } \\
\text { alunos do seu } \\
\text { curso. }\end{array}$ & ,359 & ,084 & 276 & ,402 & 1,000 & ,403 & ,389 & ,384 \\
\hline $\begin{array}{l}\text { Percebe a sua } \\
\text { função como } \\
\text { condição } \\
\text { primordial para a } \\
\text { efetivação do } \\
\text { processo de } \\
\text { ensino- } \\
\text { aprendizagem } \\
\text { do seu curso. }\end{array}$ & ,372 & 295 & ,438 & ,202 & ,403 & 1,000 & ,089 & ,346 \\
\hline $\begin{array}{l}\text { Sente-se } \\
\text { satisfeito com o } \\
\text { formato de } \\
\text { vínculo de } \\
\text { trabalho entre } \\
\text { você a } \\
\text { instituição em } \\
\text { que você atua. }\end{array}$ & ,373 & ,327 & ,357 & 650 & ,389 & ,089 & 1,000 & ,137 \\
\hline $\begin{array}{l}\text { Percebe a } \\
\text { função do tutor } \\
\text { como função } \\
\text { docente. }\end{array}$ & ,216 & ,153 & ,255 & ,227 & ,384 & ,346 & ,137 & 1,000 \\
\hline
\end{tabular}

Tabela 8 - Matriz de correlação. Elaboração própria. 
Partindo da ideia de que "grupos de variáveis podem ser inter-relacionados a ponto de todos serem representativos de um conceito mais geral" (COSTA, 2006, p. 23), foi possível perceber que para os tutores respondentes a questão de alcançar uma identidade profissional de tutor passa pela necessidade da existência de uma relação pautada na valorização da sua função por parte da instituição em que atuam.

Pode-se inferir que essa representação dos tutores referente à valorização da sua função está interligada ao fato de que eles se sentem valorizados pelos alunos e, ao mesmo tempo, percebem a sua função como condição primordial para a efetivação do processo de ensino-aprendizagem do seu curso.

Com relação aos resultados encontrados na tabela 14 correspondente à comunialidade das variáveis, foi possível perceber que as proporções de variância explicada pelos fatores comuns indicam um grau de maior associação entre as seguintes variáveis: (a) Sente-se valorizado pela instituição à qual você exerce o trabalho de tutoria; (b) Sente-se satisfeito com o formato de vínculo de trabalho entre você a instituição em que você atua e (c) Percebe a sua função como condição primordial para a efetivação do processo de ensino-aprendizagem do seu curso.

\begin{tabular}{|rlrc|}
\hline \multicolumn{1}{c}{ Variáveis } & Initial & Extraction \\
\hline 1. & $\begin{array}{l}\text { Sente-se responsável pelo desempenho e desenvolvimento } \\
\text { dos alunos na disciplina em que você atua. }\end{array}$ & 1,000 &, 380 \\
\hline 2. & $\begin{array}{l}\text { Participa da tomada de decisões concernentes ao } \\
\text { planejamento da sua disciplina. }\end{array}$ & 1,000 &, 359 \\
\hline 3. & $\begin{array}{l}\text { Percebe a sua função com clareza, no que se refere aos } \\
\text { limites de atuação das práticas de tutoria. }\end{array}$ & 1,000 & 431 \\
\hline 4. & $\begin{array}{l}\text { Sente-se valorizado pela instituição à qual você exerce o } \\
\text { trabalho de tutoria. }\end{array}$ & 1,000 &, 748 \\
\hline 5. & Sente-se valorizado pelos alunos do seu curso. & 1,000 &, 511 \\
\hline 6. & $\begin{array}{l}\text { Percebe a sua função como condição primordial para a } \\
\text { efetivação do processo de ensino-aprendizagem do seu } \\
\text { curso. }\end{array}$ & 1,000 &, 669 \\
\hline 7. & $\begin{array}{l}\text { Sente-se satisfeito com o formato de vínculo de trabalho } \\
\text { entre você a instituição em que você atua. }\end{array}$ & 1,000 &, 769 \\
\hline 8. & Percebe a função do tutor como função docente. & 1,000 &, 506 \\
\hline Tabela 9 - Comunalidades das variáveis. Elaboração própria. & & \\
\hline
\end{tabular}

Esse resultado demonstra que as variáveis destacadas têm em comum a questão da percepção dos tutores em relação à desvalorização da sua função, no que se refere à instituição ao qual exercem o trabalho de tutoria, associada à insatisfação sobre o vínculo de trabalho entre eles. Ao mesmo tempo, eles 
percebem a sua função como condição primordial para o curso, o que possivelmente contribuiu para que evidenciassem a condição de desvalorização de uma função percebida por eles como primordial para o processo de ensinoaprendizagem.

O gráfico 6 representa a variância total de cada fator analisado, demonstrando como os tutores responderam às perguntas do questionário. Percebem-se autovalores consideravelmente mais elevados à esquerda. Com relação aos menores números de fatores vemos que as variáveis 7 e 8 foram as que menos obtiveram variações nas respostas.

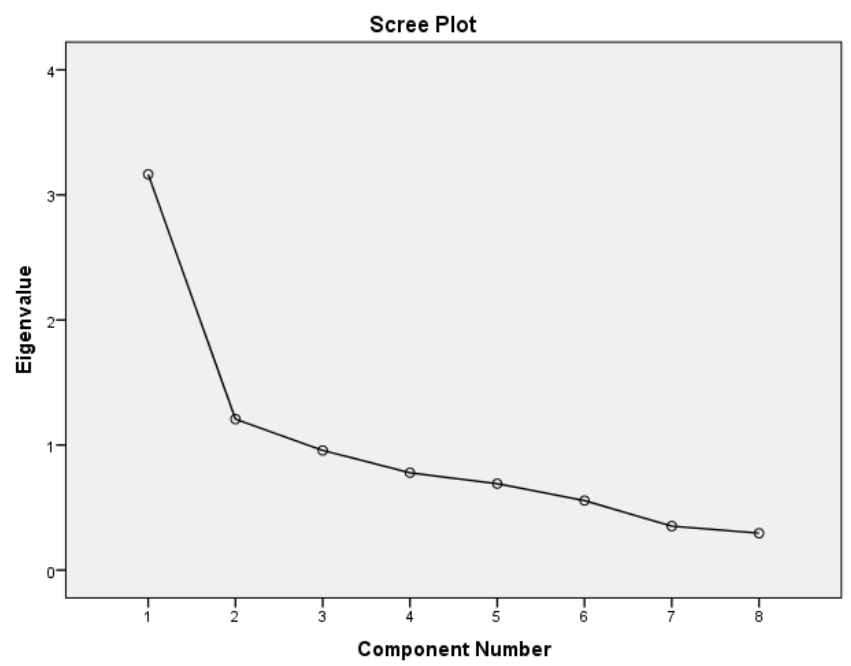

Gráfico 6: variância total dos fatores. Fonte: SPSS

Dessa maneira, a leitura dos resultados do gráfico de variância total dos fatores, confirmam a percepção dos tutores sobre o grau de insatisfação com o formato de vínculo de trabalho com a instituição em que atuam, sendo reforçado pela percepção sobre a sua função de tutoria ser uma função docente, de modo que podemos inferir que essa percepção possui relação com a necessidade de reconhecimento profissional da função e, consequentemente, da garantia dos direitos trabalhistas deles.

Os resultados da matriz de componentes na tabela 16 permite a visualização dos componentes principais das variáveis analisadas, confirmando os resultados fatoriais anteriores. Nesta matriz de correlação, as principais questões que os tutores responderam da mesma forma se concentram nas variáveis 3, 4, 5 e 7. 


\begin{tabular}{|c|c|c|}
\hline \multirow[t]{2}{*}{ Variáveis } & \multicolumn{2}{|c|}{ Componentes } \\
\hline & 1 & 2 \\
\hline $\begin{array}{l}\text { 1. Sente-se responsável pelo desempenho e desenvolvimento dos } \\
\text { alunos na disciplina em que você atua. }\end{array}$ & ,604 & ,124 \\
\hline $\begin{array}{l}\text { 2. Participa da tomada de decisões concernentes ao planejamento } \\
\text { da sua disciplina. }\end{array}$ &, 516 &,- 304 \\
\hline $\begin{array}{l}\text { 3. Percebe a sua função com clareza, no que se refere aos limites } \\
\text { de atuação das práticas de tutoria. }\end{array}$ & ,654 & ,052 \\
\hline $\begin{array}{l}\text { 4. Sente-se valorizado pela instituição à qual você exerce o } \\
\text { trabalho de tutoria. }\end{array}$ & ,740 &,- 448 \\
\hline 5. Sente-se valorizado pelos alunos do seu curso. & ,669 & ,251 \\
\hline $\begin{array}{l}\text { 6. Percebe a sua função como condição primordial para a } \\
\text { efetivação do processo de ensino-aprendizagem do seu curso. }\end{array}$ & ,611 &, 544 \\
\hline $\begin{array}{l}\text { 7. Sente-se satisfeito com o formato de vínculo de trabalho entre } \\
\text { você a instituição em que você atua. }\end{array}$ & ,690 &,- 541 \\
\hline 8. Percebe a função do tutor como função docente. &, 511 & ,494 \\
\hline
\end{tabular}

Tabela 10 - Matriz de Componentes. Elaboração própria.

Os resultados encontrados na matriz de componentes apresentam respostas significativas para as perguntas principais deste estudo, reforçando a ideia de um perfil de tutores que se sentem desvalorizados e que reconhecem com clareza os limites de sua atuação concebida por eles como docente.

O gráfico de rotação espacial representado no gráfico7 apresenta as variáveis dos dados analisados posicionadas de acordo com sua carga fatorial demonstrando que todas as variáveis foram consideradas importantes para os respondentes, uma vez que as oito questões estão no quadrante superior positivo do gráfico.

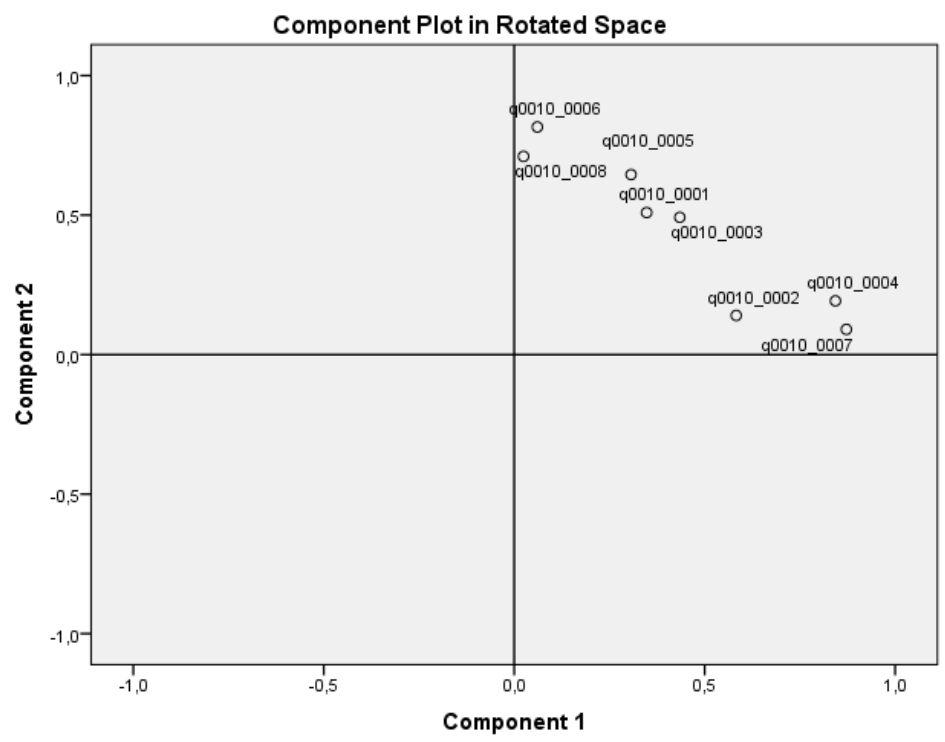

Gráfico 7: Rotação espacial. Fonte: SPSS. 
Foi possível perceber que a análise fatorial realizada neste bloco de questões, auxiliou a descoberta das variáveis latentes dos fatores analisados, concentrando-se na insatisfação dos tutores com o formato de vínculo de trabalho e na percepção deles sobre a sua função que exercem ser concebida como uma função docente evidenciando que o vínculo dos tutores como bolsistas e o não reconhecimento da sua função como docente se destacam dentro do processo de precarização do trabalho de tutoria (LAPA; PRETTO, 2010).

Nesse sentido, a técnica de análise fatorial nos permitiu validar as questões propostas no terceiro bloco, trazendo à tona informações sobre a inter-relação das variáveis e auxiliando na identificação dos fatores mais latentes do terceiro bloco de questões e que melhor respondem as questões deste estudo.

\subsection{4}

\section{Descrição e análise qualitativa: sobre a relevância e a profissionalização da função do tutor}

No bloco final de questões, buscou-se dar continuidade na identificação das percepções dos tutores sobre o lugar que eles ocupam na Educação a Distância. Para isso, elaboramos duas questões abertas, não obrigatórias, no sentido de identificar o que os tutores respondentes consideram como mais importante na função desempenhada por eles e como eles se identificam nas funções que exercem.

Dessa maneira, o bloco final foi organizado com as seguintes questões: (1) Comente algo que você considere relevante na sua função como tutor (a). (2) Você acredita que ser tutor (a) é profissão? As questões foram construídas a partir dos estudos de MILL et. al. (2008) sobre tutoria como formação docente na modalidade a distância, buscando também identificar o perfil do tutor.

Sobre a organização dos dados coletados a partir das respostas dos tutores nas duas questões abertas, optou-se pela técnica das fases que compõem a análise de conteúdo proposta por BARDIN (2006), considerando a modalidade de análise temática, dividindo a organização em três partes: (1) a pré-análise das respostas, (2) a exploração dos materiais, (3) o tratamento e análise dos resultados a partir da 
sua inferência e interpretação, por meio de uma análise crítica considerando os referenciais teóricos deste estudo.

As fases aconteceram da seguinte forma:

- Na primeira fase, realizamos a pré-análise, organizando as respostas dos tutores em duas tabelas (ver anexo A), no sentido de sistematizar as ideias.

- Na segunda fase, a partir da exploração das respostas elencadas, realizamos a inferência dos materiais coletados e a contagem frequencial dos principais temas das respostas da primeira questão. Com relação à segunda questão, realizamos o levantamento dos percentuais de "sim" e "não" das respostas dos tutores sobre a questão proposta, seguido pela contagem frequencial dos principais temas presentes nos comentários de justificativa das respostas, definindo assim as categorias de análise, no sentido de facilitar a interpretação das respostas.

- A terceira e última fase se constituiu no tratamento, inferências e interpretação dos resultados encontrados, destacando as informações, buscando interpretar os inferenciais encontrados nos materiais coletados.

Sobre as respostas da primeira questão aberta, cabe mencionar que na fase da pré-análise, observamos, durante a organização, que na resposta de número 36, o tutor respondeu com a palavra "não". Dessa maneira, como não houve resposta ao que foi solicitado na questão, a mesma foi descartada, passando de 56 para 55 respostas válidas.

Dessa maneira, a contagem frequencial realizada nas 55 respostas dos tutores em relação ao que foi solicitado na questão "Comente algo que você considere relevante na sua função como tutor", apontou para os temas elencados a na tabela 16: 


\begin{tabular}{|l|r|}
\hline \multicolumn{2}{|c|}{ Comente algo que você considere relevante na sua função como tutor } \\
\hline \multicolumn{1}{|c|}{ Temas mais frequentes nas respostas } & $\begin{array}{c}\text { Total de } \\
\text { respostas }\end{array}$ \\
\hline A importância do tutor & 28 \\
\hline Competências do tutor & 04 \\
\hline Tutoria e precarização & 03 \\
\hline Tutoria e docência & 03 \\
\hline $\begin{array}{l}\text { Outros temas: formação, relação tutor/coordenador da disciplina e formação e avaliação } \\
\text { permanente. }\end{array}$ & $\mathbf{5 5}$ \\
\hline Total de respostas mais frequentes
\end{tabular}

Tabela 11: Frequência temática das respostas para a questão 1. Fonte: Elaboração própria.

A partir dos números apresentados na tabela acima, temos o tema "A importância do tutor" com a maioria da frequência nas respostas válidas, seguido pelo tema "Competências do tutor". Além deles, com uma frequência mais baixa, estão distribuídas as respostas com as temáticas sobre "Tutoria e competência", "Tutoria e docência" e "outros temas" (formação, relação tutor/coordenador da disciplina e formação e avaliação permanente também surgiram durante a organização e pré-análise das respostas.

Nesse sentido, a partir dos temas elencados quatro categorias de análise foram delineadas, considerando os temas mais recorrentes expostos na tabela acima. Dessa maneira, para discutir essas categorias, a análise foi reorganizada em subtópicos com os seguintes títulos: (1) A importância do tutor para o Ensino a Distância, (2) As competências necessárias para o exercício da tutoria, (3) A tutoria e o processo de precarização na EAD, (4) Tutoria e Docência: onde vamos tratar sobre os limites, tensões e possibilidades dessa relação.

É importante destacar que a análise de conteúdo vai além do quantitativo de temas recorrentes, sendo necessário que estas recorrências sejam relacionadas ao contexto vivenciado pelos tutores respondentes.

Segundo CABANAS; VILARINHO (2007).

Na sua vertente qualitativa, a análise de conteúdo vai além do quantitativo de recorrências, voltando-se para o estabelecimento de inferências (interpretações / conclusões), o que exige o entrelaçamento destas ao contexto no qual são produzidas as falas dos sujeitos estudo (p. 6).

Considerando essa necessidade, após a organização dos dados obtidos nas respostas das questões abertas deste estudo, analisamos as respostas partindo do 
confronto com o referencial teórico que utilizamos neste estudo, para construir a análise dos dados nos subtópicos a seguir.

\title{
4.3.4.1
}

\section{A importância do tutor para o Ensino a Distância}

Como vimos na parte inicial deste trabalho, a Educação a Distância vem sendo construída através de uma trajetória de muitas transformações nos últimos anos, acarretando em modificações nas práticas educativas nesse formato de ensino NUNES (2013), MILL; FIDALGO (2007), VILLARDI; OLIVEIRA (2005).

Em meio a essas transformações, encontra-se o tutor, um dos principais elementos dentro dessa dinâmica de ensino, assumindo o papel de mediação pedagógica e se constituindo num dos principais elementos no processo de mediação com os alunos desta modalidade de ensino.

Corroborando com esta ideia, CAMPOS; AMARAL (2011) destacam que:

\begin{abstract}
Nesse locus, faz-se presente a "Mediação Pedagógica", atividade permanente e individualizada no processo de desenvolvimento do curso. Seu objetivo é acompanhar e oferecer aos alunos o auxílio necessário ao seu processo de autoaprendizagem, motivando-o na realização de tarefas e na relação dos conhecimentos adquiridos com a sua prática concreta (p. 50).
\end{abstract}

Nesse contexto, seria o tutor um elemento dispensável para o andamento dos cursos em formato EAD? Para o T10 (Tutor respondente número 10), essa pergunta tem uma resposta positiva, ou seja, o tutor seria um elemento dispensável:

T10 - A tutoria é hoje completamente dispensável para os gestores de CEDERJ. São mantidos somente devido às aulas práticas obrigatórias e aplicação de Ap's. (Avaliação presencial).

Em contrapartida, temos na resposta do T15 uma visão diferente da visão acima, onde a figura do tutor é percebida por ele como um elemento imprescindível para o processo de aprendizagem dentro da Educação a Distância: 
T15 - Após sete anos atuando como tutor a distância percebo que é uma figura imprescindível para que se estabeleça o processo de ensino e aprendizagem dentro da EAD. Os tutores funcionam como uma alavancagem do curso e fazem o intercâmbio entre os discentes e coordenadores de disciplina. Portanto, o coordenador que abre espaço para o seu tutor participar das tomadas de decisões da disciplina, torna o seu ambiente de aprendizagem mais enriquecedor, pois os tutores conhecem a realidade diária dos alunos.

Entretanto, é importante mencionar que se relacionarmos a resposta do T10 com os resultados da afirmativa "Sente-se valorizado pela instituição à qual você exerce o trabalho de tutoria" (que fez parte do bloco (três) 3 das questões fechadas do questionário), podemos inferir que a resposta do T10 seria resultado da sua percepção em relação a desvalorização do seu trabalho no CEDERJ, uma vez que os percentuais de maior frequência nas respostas evidenciaram a percepção dos tutores em relação a desvalorização da instituição para com a função exercida por eles.

Neste caso, para o T10, a tutoria seria algo "dispensável” pela instituição que ele atua. O termo "dispensável" utilizado pelo tutor reforça a visão sobre a desvalorização do trabalho de tutoria e sugere a fragilidade da relação entre o tutor e a instituição que ele atua. Essa fragilidade também abre caminho para uma necessidade já evidente neste estudo: o exercício de outras atividades profissionais, além da tutoria, para complementar o orçamento, como vimos no primeiro bloco de questões com o resultado expressivo de $92 \%$ dos tutores respondentes que afirmaram possuir outras atividades profissionais.

Nesse contexto, podemos inferir que a fragilidade dessa relação permeada pelo sentimento de ser "dispensável”, faz com que seja necessário estar vinculado a outro tipo de atividade profissional para garantir o seu sustento financeiro, indo de encontro ao estudo de MENDES (2013) quando ela destaca que "o trabalho no EAD não é um projeto de vida para essas pessoas. Todos desempenham outras funções ou estão em busca de outras atividades" (p. 13-14).

Entretanto, é importante mencionar que a visão do T15 sobre a importância do tutor na EAD foi frequente nas respostas, principalmente por conta do forte elo que o tutor representa dentro do universo da EAD, no que se refere ao contato com os alunos.

O contato com os alunos representa um aspecto significativo na percepção dos tutores do curso de Administração do CEDERJ/UFRRJ, assim como foi identificado em outras respostas dos tutores sobre a mesma questão: 
T37-Nosso contato com o aluno é primordial para situá-lo na modalidade de ensino EAD. Percebo os alunos muito perdidos na hora de resolver questões relevantes como dúvidas de conteúdo, revisão de nota, discussão de gabarito de prova, etc.

T45-O tutor é fundamental no processo de ensino aprendizagem dos alunos, especialmente na modalidade a distância.

T47-O tutor tem a função primordial para direcionar os alunos nos conteúdos das disciplinas.

Pode-se extrair das falas acima uma leitura sobre a importância do trabalho que esses tutores desempenham na EAD, imprimindo no perfil deles uma característica de autoreconhecimento da importância da função que eles exercem no curso de Administração do CEDER/UFRRJ.

\subsubsection{2 \\ As competências necessárias para o exercício da tutoria}

Neste subtópicos sobre as competências necessárias para o exercício da tutoria, consideramos as competências listadas na tabela 2 (dois) deste trabalho que corresponde ao quadro teórico de competências. Nesse quadro, vimos que as competências mais recorrentes, segundo os estudos de CAMPOS \& AMARAL (2007), NUNES (2013), CASTRO (2013), MENDES (2013), MILL et. al. (2008), ALONSO (2010), MACHADO; MACHADO (2004) e SILVA (2008), giram em torno do acompanhamento e auxílio frente às dúvidas dos alunos, da orientação e estímulo aos alunos relação às suas dificuldades, da participação nos processos de avaliação, do domínio dos conteúdos do curso e do uso das tecnologias que instrumentalizam todo o processo no universo virtual de aprendizagem, entre outras.

Assim como já foi mencionado anteriormente, o termo competência utilizado nesta dissertação é baseado nos estudos de CAMPOS (2009), que define competência como "a capacidade de o sujeito mobilizar recursos para resolver uma série de situações" (p.272).

Nesse contexto, considerando as respostas dos tutores e a identificação do tema "competências" como um dos mais recorrentes, cabe destacar que nas 
respostas apresentadas por eles, os conceitos de orientação e estímulo estavam presentes em sua maioria, na composição das respostas dos tutores. Além do domínio do conhecimento a ser trabalhado com os alunos.

T28-Fomentar a autonomia nos estudos da disciplina.

T18-Conhecimento do conteúdo e ser carismático.

T47-O tutor tem a função primordial para direcionar os alunos nos conteúdos das disciplinas.

T52-Ser facilitador do processo de ensino-aprendizagem.

T5-Ter total domínio e conhecimento da disciplina e buscar contínuo aperfeiçoamento.

T54-Ser um artista e fazer com que a aula pule pra fora do monitor, a fim de promover o estímulo do aluno.

Essas respostas também estão em consonância com as competências listadas em nosso quadro teórico, sugerindo que os tutores respondentes, em sua maioria, percebem as principais competências necessárias para o exercício da função de tutoria, considerando os autores que fundamentaram o quadro teórico de competências apresentado neste trabalho.

Podemos inferir que essa percepção dos tutores em relação às competências necessárias para o exercício da função de tutoria possui ligação com os resultados encontrados na questão "Você realizou formação específica em EAD?", na qual $75,8 \%$ dos tutores respondentes confirmaram possuir formação específica em EAD.

Nesse caso, acreditamos que essa percepção sobre as competências abordadas pelos tutores está relacionada aos saberes adquiridos nos cursos específicos de formação continuada dos quais eles participaram, fortalecendo a sua formação para lidar com as peculiaridades desta modalidade de ensino e atendendo, também, o Instrumento de Avaliação Externa, que destaca na Dimensão 5 (cinco), a formação do corpo de tutores como um indicador exclusivo para IES credenciada para a modalidade a distância, reforçando a necessidade de políticas para a sua capacitação (Instrumento de Avaliação Externa, 2010). 


\subsubsection{3}

\section{A tutoria e o processo de precarização na EAD}

O processo de precarização da EAD e sua relação com a tutoria surgiu como algo latente nos resultados obtidos no questionário. Vimos nas respostas das questões do segundo bloco, especificamente, nas questões que solicitavam concordância ou discordância aos itens "Sente-se valorizado pela instituição à qual você exerce o trabalho de tutoria" e Sente-se satisfeito com o formato de vínculo de trabalho entre você e a instituição em que você atua", que a maioria dos tutores respondentes discordaram parcialmente e totalmente de ambos os itens".

A exploração informal da força de trabalho que é evidenciada pelo frágil vínculo trabalhista com o CEDERJ, o baixo valor das bolsas concedidas e a falta de autonomia no exercício da sua função, são alguns indicadores que justificam a percepção dos tutores com relação à desvalorização da sua função na EAD (MENDES, 2013).

A questão da baixa remuneração é colocada como um aspecto relevante e surge como um fator significativo nas respostas à solicitação feita na primeira questão aberta "Comente algo que você considere relevante na sua função como tutor". Essa questão da baixa remuneração também surge associada ao atraso de pagamento:

T-02. A bolsa que recebemos é uma vergonha. Nosso compromisso e com o CEDERJ acaba sendo ruim por causa disso. Não temos valor. E às vezes nem recebemos e trabalhamos de graça.

T-51. Remuneração incompativel com as atividades desenvolvidas.

Esses tutores expressam uma das problemáticas que envolvem a função de tutoria na EAD: a exploração do seu trabalho. Essa questão se mostra alicerçada numa estrutura frágil em vários aspectos. A partir das respostas deles pode-se extrair a insatisfação que também surge como parte da caracterização do perfil do tutor que atua no curso de Administração do CEDERJ/UFRRJ, fortalecendo a ideia de que "o trabalho desempenhado pelo tutor é a expressão da precarização do trabalho na atualidade". (MENDES, 2013, 19). 
Além da questão que envolve a baixa remuneração, outro aspecto encontrado foi a falta de autonomia dos tutores em relação ao trabalho desenvolvido por eles, como podemos verificar na resposta do tutor abaixo:

T-48. O tutor tem pouca autonomia na construção da avaliação do aluno, apesar de ter mais contato direto com o aluno.

Além da resposta do T-48 sobre a falta de autonomia na construção da avaliação do aluno, temos também os resultados do segundo bloco de questões que evidenciam a mesma percepção dos tutores sobre a falta de autonomia no exercício da sua função na EAD. Esses resultados ficaram evidentes nas respostas das seguintes questões: (1) Com que frequência você contribui na construção das avaliações presenciais e a distância? (2) Com que frequência você participa do planejamento de trabalhos e atividades acadêmicas da disciplina que você atua? (3) Com que frequência você participa da construção do ambiente virtual da disciplina que você atua, na produção, avaliação, seleção e definição de estratégias de uso dos materiais utilizados?

Os resultados dessas questões apontaram para a falta de autonomia dos tutores, deixando transparecer a não participação da maioria dos tutores respondentes na produção das avaliações e na seleção e definição de estratégias de uso dos materiais utilizados nas disciplinas em que atuam.

Esse resultado evidencia a falta de autonomia para lidar com o planejamento dos materiais que os próprios tutores vão utilizar na interação com os alunos nos ambientes virtuais, tornando o exercício da sua função ainda mais precário.

A falta de autonomia faz parte de um dos elementos que dificultam a compreensão das atribuições do tutor na EAD, fortalecendo a indefinição do papel dos tutores, tornando as suas condições de trabalho ainda mais precárias, contribuindo de forma significativa na construção de uma identidade profissional que legitime a função do tutor.

Os resultados apontam para um perfil de tutores que demonstram insatisfação com as questões da baixa remuneração e da falta de autonomia e que necessitam não só de garantias de boas condições de trabalho, no que se refere à 
remuneração, mas também delimitações mais claras sobre a sua função na EAD (VILARINHO; CABANAS, 2008).

\subsubsection{4}

Tutoria e docência: limites, tensões e possibilidades

Algumas evidências sobre a indefinição da identidade profissional do tutor foram apresentadas neste trabalho através de autores como SANTOS; WINCHUAR (2014), NUNES (2013), MENDES, (2013) CABANAS; VILARINHO (2007) e LAPA; PRETTO (2010), que discutem as aproximações e distanciamentos dessas duas funções, tornando possível perceber as tensões geradas a respeito da questão do tutor ser ou não ser compreendido como um professor.

A questão da identidade profissional do tutor também foi evidenciada nos resultados encontrados nesta pesquisa, pois os conceitos de tutoria e docência estiveram presentes nas respostas dos tutores sobre o que eles consideram relevante na sua função como tutor. Nas respostas obtidas foi possível perceber que a figura do tutor, para eles, se assemelha à figura do docente (professor e/ou educador):

T40-O papel de educar, de transmissão de conhecimento em um sistema inovador e de grande interatividade.

T17-Como tutor presencial não posso abrir mão das funções de professor. Antes de ser tutor sou um professor, portanto é necessário rever sempre a minha prática pedagógica oferecendo aos alunos os meios para alcançar os objetivos propostos.

O respondente T-40 associa o papel de educar e transmitir conhecimentos à função do tutor. Enquanto o respondente T-17 destaca que faz uso das funções de professor como tutor presencial.

Relacionando essas respostas aos resultados obtidos no bloco 3 (três) sobre o item "Percebe a função do tutor como função docente", é possível verificar que os tutores respondentes também percebem a função do tutor como função docente, considerando os $75,4 \%$ dos respondentes que disseram concordar totalmente com a afirmação. 
A docência na EAD é distribuída em diferentes papéis LAPA; PRETTO (2010). Professores coordenadores e tutores (a distância e presencial) atuam em conjunto na organização das disciplinas dos cursos, mas cabe ao tutor o papel de interagir com os alunos no ambiente virtual e presencialmente.

Essa relação entre tutores e professores coordenadores também foi mencionada nas respostas dos tutores:

T16-Cada curso ou Universidade é de um jeito. No meu curso, o coordenador não sabia nada de EAD no início e continua não sabendo hoje. O curso é o mesmo há 10 anos.

T27- Falta integração entre tutores presenciais e os professores

Os tutores evidenciam em suas respostas o distanciamento entre tutores e professores coordenadores. Na resposta do T-16 é possível perceber que ele se refere ao conhecimento do curso, sugerindo um distanciamento do coordenador frente às questões do curso. Ao mesmo tempo, pode-se extrair dessa resposta, que o tutor conhece mais o curso do que quem o coordena.

A resposta do T-27 é clara e direta sobre a ausência de uma integração entre os tutores presenciais e professores, contrariando a ideia defendida por MILL; FIDALGO (2007) que destacam a importância da participação articulada de todos os trabalhadores envolvidos na EAD, sendo a docência para estes autores compreendida como um conceito amplo, que envolve articulação entre os trabalhadores da EAD frente ao processo de ensino-aprendizagem. "Enfim, a esse conjunto articulado de trabalhadores, necessário para a realização das atividades de ensino-aprendizagem na educação a distância, denominamos de Polidocência (MILL; FIDALGO (2007, p. 6).

Entretanto, se partimos da visão de MILL; FIDALGO (2007) sobre a Polidocência, as responsabilidades que envolvem as atividades desenvolvidas na EAD devem ser feitas de forma articulada por todos os envolvidos no processo de aprendizagem dos alunos, sendo indispensável à integração entre eles.

Nesse contexto, a ideia de Polidocência defendida por MILL; FIDALGO (2007) corrobora as respostas dos tutores em relação à falta de integração e distanciamento entre os participantes do processo de aprendizagem do curso de Administração do CEDERJ/UFRRJ, uma vez que vimos que os tutores respondentes se percebem como docentes e, ao mesmo tempo, têm conhecimento 
de que o termo docência é atribuído aos coordenadores de disciplina, que neste caso, a partir das respostas dos tutores, não estão presentes de forma articulada, como defendem MILL; FIDALGO (2007) .

SANTOS; WINCHUAR (2014) corroboram com a ideia de trabalho coletivo de MILL; FIDALGO (2007), destacando a importância do trabalho em grupo e articulado no processo de ensino aprendizagem, onde os sujeitos não podem ser vistos de forma isolada, pois se complementam na relação uns com os outros e "mesmo ocupando posições diferenciadas, possuem um perfil aproximado" (p. 15).

\section{4}

\section{Você acredita que ser tutor (a) é profissão?}

Neste tópico vamos apresentar os resultados encontrados na pergunta: "Você acredita que ser tutor (a) é profissão?". Assim como foi mencionado anteriormente, trata-se da segunda pergunta aberta do questionário, de caráter não obrigatório aos tutores respondentes.

Buscou-se identificar nas respostas desta questão elementos que sirvam de indicadores sobre a percepção que os tutores têm em relação à função que exercem, especificamente, se acreditam que ser tutor é profissão.

É importante ressaltar que a função ainda não foi reconhecida profissionalmente e o tutor acaba por exercer um papel de mero coadjuvante nas IES, pois sem a profissionalização da função, os direitos trabalhistas do tutor vão continuar sendo negados, considerando que não há lei que o ampare profissionalmente.

Em contrapartida, assim como já foi mencionado anteriormente neste trabalho, existe um projeto de lei a respeito da profissionalização dos tutores da EAD (PL2435/201), que tem como objetivo regulamentar o exercício da atividade de Tutoria na EAD. Esse projeto está em andamento na Câmara dos Deputados desde 2011 e tem como autor o deputado Ricardo Izar, do Partido Verde de São Paulo.

Dessa maneira, questionar os tutores sobre a crença deles em relação a acreditar ou não na tutoria como profissão, é buscar identificar a percepção sobre 
como eles se percebem dentro dessa relação de trabalho desprovida de uma legislação específica. Seriam eles profissionais ou prestadores de serviço?

Sobre a organização dos dados das respostas, exportamos os resultados pelo SPSS e organizamos uma tabela (ver apêndice B) com as 39 respostas coletadas. Dentro desse universo de respondentes, 33 tutores disseram acreditar que a função de tutor é uma profissão.

É importante destacar que a maioria das respostas não foi justificada pelos tutores respondentes, sendo respondida com "sim" ou "não", mas todas as respostas foram consideradas na análise dos resultados desta pergunta.

A resposta abaixo é um dos exemplos de resposta justificada e ilustra a percepção da maioria dos tutores sobre a sua função:

T36-Sim. Nós tutores somos tratados como uma categoria inferior aos professores. Mas, esta é uma percepção errônea da tutoria. Me considero uma PROFESSORA. Não possuo qualquer formação pedagógica, mas, minha atuação como tutora é, pra mim, uma espécie de atuação docente.

A reposta do T36 destaca a sua percepção quanto à inferiorização da função de tutoria, mas também sugere que a tutora se percebe como docente, mesmo não possuindo, segundo a resposta, formação pedagógica.

A resposta do T36 nos leva a refletir sobre a construção da identidade partindo da ótica de TARDIF; RAYMOND (2000) pautada na relação entre o trabalhador e o trabalho, em que ambos acabam transformando um ao outro. Nessa relação, saberes são construídos de acordo com a ocupação dos envolvidos "progressivamente durante um período de aprendizagem variável, de acordo com cada ocupação” (TARDIF; RAYMOND, 2000 p211).

Nesse sentido, a resposta do T36 sugere que a sua percepção em relação à docência foi construída pelo próprio processo de trabalho na tutoria, ocasionada por saberes ligados à sua prática, o que segundo ela, independe de qualquer formação específica.

A ideia da construção da identidade profissional baseada nas relações entre o trabalhador e o trabalho nos permite perceber que independente da profissionalização da função do tutor, a identidade desse sujeito vem sendo delineada pelos saberes que são construídos nas relações com os alunos, "saberes oriundos do próprio processo de trabalho nele baseados. Ora, são exatamente 
esses saberes que exigem tempo, prática, experiência, hábito etc" (TARDIF; RAYMOND, 2000 p.211).

É importante destacar que quando nos referimos à modalidade de ensino a distância, os saberes necessários para o exercício das práticas desenvolvidas nesse universo, assumem uma conotação diferenciada, no que se refere às ferramentas comunicacionais utilizadas no processo de ensino-aprendizagem, buscando garantir a intercomunicação entre todos os participantes.

Para CAMPOS; AMARAL (2011):

O Mediador Pedagógico precisa estruturar sua tarefa estabelecendo contato com o aluno por meio das ferramentas comunicacionais que tenha ao seu alcance como, por exemplo, grupos e listas de discussão, correio-eletrônico e chat. Assim, tornase possível traçar um perfil completo do aluno, seja pelo trabalho que ele desenvolve, pelo seu interesse ou por sua vontade de aprender. A atividade do mediador pedagógico garante, assim, a intercomunicação entre todos os atores do processo (professor-autor - mediador - aluno) e reúne uma função tríplice: orientação, docência e avaliação (p. 54).

A garantia dessa intercomunicação vai exigir dos tutores um perfil profissional que atenda à essa necessidade, permitindo que eles consigam lidar com as peculiaridades que fazem parte da Educação a Distância, especificamente, do processo de aprendizagem dos alunos, além de ser o elo de intercomunicação entre todos os participantes desse processo.

Nesse contexto, vemos que a função do tutor envolve múltiplas atividades, que vão além da interação com os alunos através da sala de tutoria do Ambiente Virtual das disciplinas. Entretanto, ao assumir múltiplas atividades, corre-se o risco de ir além das atribuições previstas, assumindo responsabilidades que não fazem parte da função do tutor:

Os professores e os tutores que atuam nos cursos possuem responsabilidades diferentes. De acordo com Mendes (2012, p. 121), “[...] pode-se dizer que, [...], ao professor cabe organizar e planejar a disciplina e, em alguns casos, a correção de algumas tarefas. Já ao tutor cabe o esclarecimento de dúvidas, o acompanhamento do aluno e a correção de trabalhos". Entretanto, não raras vezes, as funções do professor também são assumidas pelo tutor (MENDES, 2012, p. 13).

A questão destacada por MENDES evidencia a ausência de uma legislação que trate diretamente dos limites de atuação do tutor, pois essa questão interfere diretamente na indefinição da sua identidade no cenário da Educação a Distância. 
Assim, o tutor acaba assumindo diferentes papéis, inclusive responsabilidades que pertencem aos coordenadores, tornando a sua função mais trabalhosa e complexa. Sobre essa questão, foi possível perceber na resposta do T.5 que ele percebe a função do tutor como uma forma de docência mais trabalhosa e difícil, sugerindo a possibilidade dessa visão ter como referência a realização de tarefas que vão além da sua responsabilidade:

T5-Claro que sim, é uma forma de docência só que no ambiente virtual, o que é muito mais trabalhoso e difícil.

Entretanto, podemos inferir a partir da resposta do T-5, que a tutoria não deve ser vista de forma reducionista, pois envolve uma série de caraterísticas que a torna complexa, trabalhosa e relevante, assim como a docência.

LAPA; PRETTO (2010) apontam outras tensões geradas a partir da distribuição de tarefas destacando que:

É possível reconhecer essa dificuldade, por exemplo, quando o professor não trata o tutor como um professor como ele e atribui à tutoria um papel administrativo, de cobrar presença e trabalhos. Ou quando o professor planeja tudo sozinho e espera que os outros professores e tutores apenas executem a sua proposta, quando esses sequer conseguem compreender os objetivos pedagógicos que a orientaram, tornando-se, assim, um professor de script de autoria alheia (p. 85).

Diante das questões expostas, percebe-se que a função do tutor é permeada por tensões que envolvem os limites de sua atuação, interferindo na construção de uma identidade que legitime a sua função na EAD. Ao questionar os tutores sobre a crença deles em relação a acreditar ou não na tutoria como profissão, foi possível identificar que eles a percebem como profissão e procuram, em sua maioria, aproximá-la da função docente.

Até mesmo nas respostas dos tutores que disseram não acreditar que ser tutor é profissão foi possível identificar a percepção deles de que a função que desempenham é algo que requer responsabilidade dentro do processo de aprendizagem, assim como também, a crença de que muito em breve a tutoria será reconhecida e legitimada como profissão:

T12-Não, mas requer toda a responsabilidade na condução do processo de aprendizagem.

T13-Não! Mas acho brevemente isto vai acontecer. 
Os resultados da pergunta deste tópico apontam para um perfil de tutores que acreditam que a função desempenhada por eles na EAD é uma profissão. Ao mesmo tempo, foi possível perceber também na análise das respostas que existe uma necessidade de aproximação da função com a docência, muito embora, permeada por conflitos relacionados à ausência de limites de atuação, gerada pela falta de uma legislação que profissionalize a função legitimando as suas reais atribuições. 


\section{5 \\ Apontamentos finais: algumas respostas encontradas}

Este trabalho teve como objeto de análise a compreensão da identidade profissional do tutor. Buscou-se identificar o perfil e as percepções dos tutores do curso de Administração do CEDERJ/UFRRJ acerca do papel que desempenham no contexto da Educação a Distância. A construção do objeto de pesquisa deste trabalho passou pela experiência que vivenciei em minha trajetória como tutora, sendo de grande valia para o amadurecimento das questões deste estudo, me motivando a colaborar na contribuição do reconhecimento de uma classe de trabalhadores, ao qual eu pertenço e que carece da profissionalização da sua função, tendo em vista a importância do seu trabalho na EAD.

Nesse sentido, discutimos as práticas desenvolvidas pelos tutores no universo da Educação a Distância, uma vez que ainda não houve avanços frente à compreensão da sua função e, consequentemente, na compreensão da sua identidade profissional.

A seguir, apresento as respostas encontradas nesta pesquisa, sistematizando os principais achados a partir dos resultados encontrados em cada bloco de questões.

Em resposta à primeira questão deste estudo, os resultados do primeiro bloco de questões apontou que o curso de Administração do CEDERJ/UFRRJ é composto por 117 tutores, que em sua maioria atuam presencialmente.

Com relação à faixa etária dos tutores vimos que se trata de um grupo jovem, no qual a maior distribuição de idade entre os tutores respondentes se concentra nas faixas dos 30 aos 35 anos e dos 36 aos 44 anos.

Sobre o perfil de formação dos tutores, trata-se de um grupo, em sua maioria, de tutores especialistas na área da Educação a Distância, atendendo às exigências estabelecidas nos dois últimos Instrumentos de Avaliação Externa (2010/2014), que consideram a graduação do corpo de tutores presenciais e a distância como um referencial mínimo de qualidade, sendo indispensável para o credenciamento das IES na modalidade a distância. 
Sobre o tempo de trabalho na tutoria no curso de Administração do CEDERJ/UFRRJ foi possível perceber que a maior concentração das respostas dos tutores respondentes indica que os mesmos estão de 4 a 8 anos no trabalho de tutoria, assumindo também outras atividades profissionais concomitantemente à tutoria.

A partir das respostas do primeiro bloco de perguntas foi possível identificar um perfil de tutores jovens, com formação adequada para exercer a tutoria e que estão desenvolvendo uma função que requer a busca de outras atividades profissionais, evidenciando que o trabalho de tutoria não se constitui num único vínculo de trabalho, sendo concebido como um trabalho com flexibilidade espaço-temporal, corroborando com MILL et. al. (2008), pois para eles "a tutoria é um trabalho com flexibilidade espaço-temporal, que pode ser executado concomitantemente a outras atividades profissionais e que não demanda tanto esforço do trabalhador" (p. 68).

O discurso da flexibilidade espaço-temporal do trabalho de tutoria destacado por MILL et. al. (2008) maquia a sobrecarga de trabalho reforçando o processo de precarização do trabalho do tutor. Desse modo, torna-se possível perceber que a questão da flexibilidade espaço-temporal aliada à sobrecarga de trabalho faz parte dos resultados obtidos nas respostas do primeiro bloco de questões e que ambos os aspectos estão presentes nas características do perfil dos tutores respondentes que exercem outras atividades profissionais além da tutoria.

O segundo bloco de questões buscou identificar as práticas predominantes no trabalho de tutoria e a relação do tutor com a função que exerce no contexto em que o seu trabalho está inserido, buscando a aproximação dessas práticas com a docência e/ou com ações que se aproximem ao viés administrativo, no sentido de responder a questão: "A identidade do tutor na Educação a Distância se constrói buscando uma aproximação com a docência ou se estabelece no viés burocrático-administrativo?”.

A primeira questão do segundo bloco apontou que apesar das condições que evidenciam a precarização da atividade de tutoria, os tutores respondentes, em sua maioria, conhecem o projeto político-pedagógico do seu curso, demonstrando uma disposição subjetiva em relação ao envolvimento deles com a proposta e objetivos pedagógicos traçados pelo curso, evidenciando a existência de uma 
relação de trabalho que ultrapassa as barreiras impostas pelas dificuldades ocasionadas pela precarização da sua função na EAD.

As respostas relacionadas as quatro primeiras $^{21}$ perguntas deste bloco, apontam para um perfil de tutores que se divide em suas interações com os alunos, entre as questões burocráticas do curso e o exercício da função voltada para os temas propostos pela disciplina que atua.

Com relação aos resultados encontrados nas respostas das perguntas (5) "Com que frequência você contribui na construção das avaliações presenciais e a distância?"; (6) "Com que frequência você participa do planejamento de trabalhos e atividades acadêmicas da disciplina que você atua?" e a questão (7)" Com que frequência você participa da construção do ambiente virtual da disciplina que você atua, na produção, avaliação, seleção e definição de estratégias de uso dos materiais utilizados?" vimos que os resultados apontam para uma participação reduzida da maioria dos tutores respondentes, no que se refere à produção das avaliações e à seleção e definição de estratégias de uso dos materiais utilizados nas disciplinas em que atuam, evidenciando a falta de autonomia dos tutores respondentes para lidar com o planejamento dos materiais das disciplinas que atuam.

Encerrando o segundo bloco de questões sobre as práticas predominantes no trabalho de tutoria apresentamos os resultados da pergunta 8 (oito): "Você costuma utilizar as ferramentas da Plataforma do Cederj durante o seu trabalho de tutoria? (Exemplos: o portal Teca, ambiente de avisos, e-mail do CEDERJ, Wiki e etc.)". Nesta questão, encontramos um percentual maior nas respostas referentes a "muitas vezes" (38,5\%) e "sempre" (26,2\%), frente aos percentuais de baixa frequência nas respostas "nunca" (9,2\%) e "poucas vezes" $(26,2 \%)$.

Sobre os resultados encontrados nesta pergunta percebe-se que os resultados deste bloco de questões aponta para um perfil de tutores que se divide entre ações docentes e administrativas, uma vez que os tutores interagem com os

\footnotetext{
${ }^{21}$ Com que frequência você percebe em sua interação com os alunos que eles apresentam uma postura autônoma em relação ao processo de aprendizagem?; (2) Com que frequência a interação com os alunos está voltada para os temas específicos da sua disciplina?; (3) Com que frequência você utiliza com os alunos vídeos, livros digitais e revistas eletrônicas para ampliar a discussão sobre os temas da disciplina?; (4) Na sua interação com os alunos, as questões relacionadas ao universo acadêmico-administrativo do curso aparecem com qual frequência? (Ex: prazo de envio de trabalho, notas, data de provas, problemas gerais na plataforma, documentos e etc.
} 
alunos sobre os temas da disciplina, juntamente com as ações de ordem burocrática do curso, atendendo às demandas administrativas dos alunos.

O terceiro bloco e o bloco final de perguntas buscaram identificar as percepções dos tutores sobre a sua função e sobre o lugar que eles ocupam na EAD, no sentido de responder a questão "Quais são as percepções que o tutor possui acerca do lugar que ele ocupa na Educação a Distância?”.

A primeira questão do bloco 3 (três) teve como objetivo, identificar o grau de percepção dos tutores em relação à sua percepção sobre a responsabilidade da função que desempenha frente ao desenvolvimento dos alunos. Os resultados apontaram para um grau de concordância expressivo nesta afirmação $(87,7 \%)$, demonstrando que a maioria dos tutores respondentes se sente responsável pelo desempenho e desenvolvimento dos alunos nas disciplinas em que atuam.

A segunda afirmação do terceiro bloco de questões "Participa da tomada de decisões concernentes ao planejamento da sua disciplina" apontou para um percentual que caracteriza o distanciamento dos tutores em relação ao planejamento da disciplina, reforçando o delineamento de um perfil que vem sendo construído frente à falta de autonomia do tutor com relação às disciplinas que atuam, contrariando a necessidade do tutor participar dos processos avaliativos e de planejamento das disciplinas, uma vez que planejar, acompanhar e avaliar atividades, são características relevantes que devem fazer parte da função do tutor (MACHADO; MACHADO, 2004).

Sobre a afirmativa "Percebe a sua função com clareza no que se refere aos limites de atuação das práticas de tutoria”, os tutores respondentes, em sua maioria, concordaram com a afirmação, caracterizando o perfil do grupo pesquisado com mais um aspecto relevante para o desempenho da função de tutoria: a percepção dos tutores sobre os limites de atuação das suas práticas. Conhecer os limites de atuação que cercam a função a ser desempenhada por eles é de fundamental importância para o trabalho de tutoria, uma vez que o tutor se constitui num dos principais agentes da mediação pedagógica na EAD (CASTRO, 2013).

Com relação à afirmativa "Sente-se valorizado pela instituição à qual você exerce o trabalho de tutoria" houve uma discordância na maioria das respostas dos tutores, demonstrando o sentimento de desvalorização dos tutores com relação ao trabalho desenvolvido por eles no CEDERJ/UFRRJ. Essa questão mostrou que os 
tutores não se percebem valorizados pela instituição à qual estão vinculados. Esse resultado se relaciona diretamente com os resultados com a afirmativa "Sente-se satisfeito com o formato de vínculo de trabalho entre você a instituição em que você atua". Os resultados também apontaram para um número bem expressivo de discordância dos tutores respondentes, demonstrando o desconforto e a insatisfação com o frágil vínculo de trabalho.

Assim como foi visto na discussão teórica a partir dos estudos de LAPA; PRETTO (2010), o não pagamento de uma remuneração justa e a ausência de um vínculo de trabalho adequado para os tutores bolsistas são aspectos que fortalece o processo de precarização do trabalho do tutor.

Em contrapartida, os resultados sobre a afirmação "Sente-se valorizado pelos alunos do seu curso", apontaram para uma percepção positiva por parte da maioria dos tutores respondentes, demonstrando que possivelmente, a interação entre os tutores e alunos no curso de administração do CEDERJ/UFRRJ oferece elementos para um bom relacionamento entre eles, traduzindo o percentual de respostas acerca do sentimento de valorização da função deles pelos alunos do curso.

Nessa mesma direção, na afirmativa "Percebe a sua função como condição primordial para a efetivação do processo de ensino-aprendizagem do seu curso", os tutores responderam em concordância com esta afirmação, sendo possível identificar um perfil de tutores que mesmo vivenciando um universo que evidencia a precarização do seu trabalho, percebe a importância da sua função para a efetivação do processo de aprendizagem do seu curso.

A utilização da técnica de análise fatorial realizada no terceiro bloco de questões contribuiu para a descoberta das variáveis dos fatores analisados, tornando possível perceber a insatisfação dos tutores com o formato do vínculo de trabalho, assim como também a percepção deles sobre a sua função ser entendida como função docente.

Nesse sentido, a análise fatorial realizada nos permitiu validar as questões propostas no terceiro bloco e identificar os fatores que melhor responderam às questões deste estudo, apontando para uma característica marcante no perfil do grupo de tutores respondentes: a percepção da desvalorização do seu trabalho pela instituição em que exercem a tutoria. 
Em resposta à questão "Qual a relação entre os documentos oficiais que fazem referência à tutoria no Brasil e a construção da identidade do tutor?" identificou-se através da pesquisa bibliográfica realizada referente às fontes das leis e Decretos relacionados à Educação a Distância e selecionados para este estudo, que os materiais selecionados evidenciam o distanciamento entre as funções de tutoria e docência. Entretanto, em resposta ao item "Percebe a função do tutor como função docente" os tutores $(75,4 \%)$ concordaram totalmente, demonstrando que mesmo diante de um distanciamento legal que sugere o distanciamento entre tutoria e docência, eles se percebem como docentes no exercício de suas práticas na EAD.

A percepção dos tutores respondentes em relação ao trabalho de tutoria ser um trabalho que pode ser visto como docência não deixa de evidenciar as mazelas que se agregam à sua função entendida por eles como docente.

A partir da análise dos resultados das questões abertas ficou perceptível que as respostas dos tutores apontaram para a falta de autonomia deles no desempenho de suas funções percebidas como docentes. Esses resultados deixam transparecer a não participação da maioria dos tutores respondentes na produção das avaliações e na seleção e definição de estratégias de uso dos materiais utilizados nas disciplinas em que atuam e possivelmente são frutos das lacunas existentes nas leis e Decretos relacionados à Educação a Distância discutidas neste trabalho.

Além disso, os resultados encontrados nas respostas abertas evidenciam a falta de autonomia e a ausência de leis que garantam a profissionalização da função do tutor na EAD e tornam o exercício dessa função ainda mais precário.

Sendo assim, percebe-se que o tutor, na verdade, busca uma aproximação do seu trabalho ao trabalho docente, na tentativa de ser percebido e respeitado como docente, com as mesmas garantias e direitos, conferindo dignidade e respeito à sua função, no que tange às questões de ordem trabalhista.

Nesse contexto, os resultados desta pesquisa apontam para um perfil de tutor que ainda permanece na indefinição do seu papel no que se refere à legislação e, até mesmo, ao olhar que a instituição em que trabalham atribui a eles. Contudo, conseguem perceber claramente a sua função com a devida relevância que representa para o processo de aprendizagem na EAD. 
Dentro desse universo de contradições e desvalorização da função do tutor na EAD, a identidade desse sujeito encontra-se indefinida legalmente, desprovida de direitos trabalhistas que ocasionam a falta da sua legitimação no cenário educacional.

As incertezas e precariedades fazem parte do processo de construção da identidade profissional do tutor, sendo entendido neste estudo como aspectos inerentes ao processo de construção da identidade profissional, em concordância com as ideias de DUBAR (1997) acerca da construção da identidade em meio às incertezas e precariedades, sendo por meio delas que a identidade do sujeito se constrói ao longo da vida.

A identidade do tutor se constrói na dinâmica do seu trabalho, no exercício da sua prática, na interação com os alunos e que tais práticas geram experiências que certamente estão presentes na constituição da sua identidade em formação e que se aproximam bastante das práticas docentes, reforçando a ideia de que não deveria haver diferenciação entre tutoria e docência.

Nesse sentido, a concepção de TARDIF; RAYMOND (2000) acerca de que quem modifica o trabalhador é o trabalho e que essa relação interfere na construção da identidade do trabalhador, se encaixa perfeitamente na trajetória identitária do tutor do curso de Administração do CEDERJ/UFRRJ.

As características da docência aliada a questões de cunho administrativo estão presentes na função desempenhada por eles, uma vez que os resultados apontaram que eles compartilham o trabalho com os coordenadores das disciplinas que atuam, aproximando-se de certa forma, de um modelo de trabalho coletivo que ainda não consegue se organizar dentro dos limites de atuação de cada ator, pois, em vários momentos, os tutores sinalizaram exercer funções que vão além das suas atribuições, ou, até mesmo, apontaram para o fato de ter mais domínio das questões da disciplina do que os próprios coordenadores. Esse aspecto me levou a pensar que o trabalho coletivo na EAD precisa ser repensado, pois a Polidocência que muitas vezes justifica essa prática, pode estar sendo entendida de forma equivocada, uma vez que esse conceito passa pela ideia de trabalho coletivo, no qual a participação de todos os envolvidos no processo de aprendizagem fique bem delimitada e garantida.

Entretanto, acredito que a função do tutor deve ir além do conceito de Polidocência proposto por MILL; FIDALGO (2007), na qual o tutor esteja 
assumindo um lugar singular na $\mathrm{EAD}$, em meio à coletividade de diferentes papéis e funções, de modo que ele alcance a garantia dos seus direitos trabalhistas e, principalmente, conquiste um espaço bem delimitado no quadro de trabalhadores que atuam na docência nesta modalidade de ensino.

Sendo assim, concluo que o trabalho do tutor vai além do suporte virtual, se constituindo numa função ainda em processo de construção de identidade profissional, mas que aponta para a necessidade de legitimação e profissionalização de sua prática, esta que é revestida de características docentes, mas com peculiaridades e competências próprias do universo da Educação a Distância, sugerindo uma nova forma de profissional docente que já se percebe nessa condição, mas que ainda depende da sua profissionalização.

Pretendo continuar discutindo a questão da identidade do tutor em estudos posteriores, buscando a percepção dos alunos sobre esse personagem e de suas práticas, no que se refere à relação tutor/aluno, de forma a continuar contribuindo na ampliação da visão sobre os limites de atuação dos tutores e sobre o espaço que ocupam na modalidade de ensino a distância. 


\section{6 Referências bibliográficas}

ALVES, A.J.A. Revisão da Bibliografia em Teses e Dissertações: Meus Tipos Inesquecíveis. Cadernos de Pesquisa, nº81, p. 53-60, maio, 1992.

ALONSO, K. M. A expansão do ensino superior no Brasil e a EaD: dinâmicas e lugares. Educ. Soc. Campinas, v. 31, n. 113, p. 1319-1335, out.-dez. 2010.

BARDIN, L. (2006). Análise de conteúdo (L. de A. Rego \& A. Pinheiro, Trads.). Lisboa: Edições 70. (Obra original publicada em 1977). Disponível em: http://pt.slideshare.net/RonanTocafundo/bardin-laurence-anlise-de-contedo. Acesso em 31 de janeiro de 2016.

BRASIL, Ministério da Educação/ Secretaria de Educação a Distância. Referenciais de qualidade para cursos a distância. Disponível em: http://portal.mec.gov.br/seed/arquivos/pdf/referenciais.pdf. Acesso em: 19 de set 2014.

BRASIL. Resolução CD/FNDE $\mathbf{n}^{\mathbf{0}}$ 26, de 5 de junho de 2009. Brasília: Ministério da Educação. Coordenação de Aperfeiçoamento de Pessoal de Nível Superior/Universidade Aberta do Brasil. Disponível em: $<$ http://uab.capes.gov.br/index.

php?option=com_content $\&$ view=article\&id=9\&Itemid=21>. Acesso em: 10 mar. 2014.

BRASIL, Decreto 42.765 - 22/12/10, SUNOP/SILEP de 27 de dezembro de 2010. Rio de Janeiro: Regimento interno da fundação centro de ciências e educação superior a distância do estado do rio de janeiro - Fundação CECIERJ. Disponível em: http://CEDERJ.edu.br/fundacao/regimento-interno/ Acesso em out. 2014.

BRASIL. Ministério da Educação. 2007. Referenciais de Qualidade para Educação Superior a Distância. Disponível em: 
http://portal.mec.gov.br/seed/arquivos/pdf/legislacao/refead1.pdf Acesso em out. 2014.

BRASIL. Ministério da Educação. Resolução n. 26, de 5 de junho de 2009. Estabelece orientações e diretrizes para o pagamento de bolsas de estudo e de pesquisa a participantes da preparação e execução dos cursos dos programas de formação superior, inicial e continuada no âmbito do Sistema Universidade Aberta do Brasil (UAB), vinculado à Coordenação de aperfeiçoamento de Pessoal de Nível Superior (Capes), a serem pagas pelo FNDE a partir do exercício de 2009.

BRASIL. Ministério da Educação. Lei no 11.180, de 23 de setembro de 2005 Institui o Programa de Educação Tutorial - PET. Disponível em http://portal.mec.gov.br/index.php?option=com_content\&id=12227\%3Aprograma -de-educacao-tutorial-pet\&Itemid=480. Acesso em fevereiro de 2015.

BRASIL. Ministério da Educação. Portaria n ${ }^{\circ}$ 343, de 24 de abril de 2013 Altera dispositivos da Portaria MEC n 976, de 27 de julho de 2010, que dispõe sobre o Programa de Educação Tutorial - PET. Disponível em http://portal.mec.gov.br/index.php?option=com_content\&id=12227\%3Aprograma -de-educacao-tutorial-pet\&Itemid=480. Acesso em fevereiro de 2015.

BRASIL, Projeto de Lei n. 2435/2011 - Dispõe sobre a regulamentação do exercício da atividade de Tutoria em Educação a Distância. Disponível em: http://www.camara.gov.br/proposicoesWeb/fichadetramitacao?idProposicao=522 182. Acesso em 01 de fevereiro de 2016.

BRASIL. Instituto Nacional de Pesquisas Educacionais - Anísio Teixeira. Censo de Educação Superior 2013. Disponível em: http://portal.inep.gov.br/web/censoda-educacao-superior. Acesso em 23 de dezembro de 2015.

BRASIL, Instituto Nacional de Estudos e Pesquisas Educacionais Anísio Teixeira. Instrumento de Avaliação Institucional Externa. Brasília, setembro de 2010. Disponível em: http://download.inep.gov.br/download/superior/institucional/2010/instrumento_av aliacao_institucional_externa_recredenciamento.pdf. Acesso em 21 de setembro de 2015 . 
BRASIL. Instituto Nacional de Estudos e Pesquisas Educacionais Anísio Teixeira. Instrumento de Avaliação Institucional Externa. Subsidia os atos de credenciamento, recredenciamento e transformação de organização acadêmica (presencial).

Disponível

em: http://download.inep.gov.br/educacao_superior/avaliacao_institucional/instrument os/2014/instrumento_institucional.pdf. Acesso em 01 de fevereiro de 2016.

BRAVO, R. S. Técnicas de investigação social: Teoria e exercícios. 7 ed. Ver. Madrid: Paraninfo, 1991.

BELLONI, Maria Luiza. Ensaio sobre a Educação a Distância no Brasil. Educação \& Sociedade, ano XXIII, nº 78, Abril/2002.

BELLONI, M. L. Educação a Distância. $4^{\text {a }}$ ed. Campinas, São Paulo: Autores Associados, 2001. 115p.

CABANAS, Maria Inmaculada Chao. VILARINHO, Lúcia Regina Goulart. Educação a Distância: tutor, professor ou tutor-professor? E-TIC, $5^{\circ}$ Encontro de Educação e Tecnologias de Informação e comunicação. Universidade Estácio de Sá, Mestrado em Educação e Cultura Contemporânea. Novembro - 2007.

CAMPOS, Gilda Bernardino de. EAD: Mediação e aprendizagem durante a vida toda. In: LITTO, Frederic M. FORMIGA, Marcos. Educação a Distância: O estado da arte. São Paulo, Pearson Education do Brasil, 2009.

CAMPOS, Gilda Helena Bernardino de, AMRARAL, Sérgio Botelho. Mediação Pedagógica: cooperação entre pares como estratégia pedagógica. In: CAMPOS, Gilda Helena Bernardino de, ROQUE, Gianna O. Bogossian, AMRARAL, Sérgio Botelho. As relações colaborativas: desafios da docência na Educação a Distância. Curitiba, PR: CRV, 2011.

CALADO, S.dos S; Ferreira, S.C dos R. Análise de documentos: método de recolha a análise de dados. Disponível em:http://www.educ.fc.ul.pt/docentes/ichagas/mi1/analisedocumentos.pd. Acesso em 25 de janeiro de 2015.

CASTRO e SILVA, Eunice de. Concepção dos Alunos sobre Mediação Pedagógica: um estudo de caso em curso na modalidade a distância. Dissertação de Mestrado - PUC - Rio, 2013. 
COSTA, Giovani Glaucio de Oliveira. Um procedimento inferencial para análise fatorial utilizando as técnicas Bootstrap e Jackknife: construção de intervalos de confiança e testes de hipóteses. Tese (doutorado) - Pontifícia Universidade Católica de Rio de Janeiro, Departamento de Engenharia Elétrica, 2006.

CONVENÇÃO COLETIVA que, entre si, fazem, de um lado, o Sindicato dos Professores do Município do Rio de Janeiro e Região - SINPRO-RIO, CNPJ ${ }^{\circ}$ 33.654.237/0001-45, e, de outro lado, o Sindicato das Entidades Mantenedoras de Estabelecimentos de Ensino Superior do Estado do Rio de Janeiro - SEMERJ, CNPJ n 4 6.511/0001-87. Rio de Janeiro, 01 de abril de 2014. Disponível em www.sinprorio.org.br/download/convencoes/2014/superior2014.doc. Acesso em 15 de abril de 2015.

CENSO EAD.BR: Relatório Analítico da Aprendizagem a Distância no Brasil. ABED - Fundação Getúlio Vargas. São Paulo, 2013. Disponível em : http://www.abed.org.br/censoead2013/CENSO_EAD_2013_PORTUGUES.pdf. Acesso em 23 de novembro de 2014.

DEMO, Pedro. Pesquisa e informação qualitativa: aportes metodológicos. Campinas, São Paulo. Papirus, 2001.

DEMO, Pedro (1998). Questões para a Teleducação. Petrópolis: Vozes.

DUBAR, C. (1997). A socialização: Construção das identidades sociais e profissionais. Porto: Porto Editora.

DUBAR, C. 2000 La Socialisation: Construction des Identités Sociales et Professionnelles. Paris: Armand Colin.

EDITAL PARA SELEÇÃO DE TUTORES PARA OS CURSOS DE GRADUAÇÃO DO CONSÓRCIO CEDERJ. Fundação Cecierj - Consórcio Cederj, 2015. Disponível em: http://cederj.edu.br/fundacao/selecao-de-tutores/. Acesso em 19 de dezembro de 2015.

FEIJOO, Ana Maria Lopez Calvo de. A pesquisa e a estatística na psicologia e na Educação. Rio de Janeiro: Bertrand Brasil, 1996.

FLEURY, Maria Tereza Leme. FLEURY, Afonso. Construindo o Conceito de Competência. RAC, Edição Especial 2001: 183-196. 
FREIRE, Djenane Luisa. CONSÓRCIO CEDERJ: as fragilidades de duas dimensões da organização. Dissertação de Mestrado. Rio de Janeiro, UFRJ/FE/PPGE, 2013.

FURTADO, Valéria Almeida. A formação em serviço do tutor de Educação a Distância sob a ótica do pensamento complexo: a construção de uma identidade. Tese de doutorado - PUC-SP, 2009.

GATTI, A. B.; BARreto, E. S.; ANDRÉ, M. E. D. Políticas Docentes no Brasil: um Estado da Arte. Brasília: UNESCO, 2011.

GATTI, Bernardete A. Formação de professores: condições e problemas atuais. Revista Brasileira de Formação de Professores, v. 1, n. 1, p. 90-102, maio, 2009.

GIL, Antonio Carlos. Como elaborar projetos de pesquisa, SP: Atlas, 2002.

GOMES, Ednaldo Farias. Perfil e identidade do tutor em cursos na modalidade a distância do IFAL vinculados ao Sistema Universidade Aberta do Brasil: definições e prática docente. Revista Eletrônica Multidisciplinar Pindorama do Instituto Federal de Educação, Ciência e Tecnologia da Bahia - IFBA, No 01 Ano I - Agosto/2010.

GOMES, Ednaldo Farias. Perfil e identidade do tutor em cursos na modalidade a distância do IFAL vinculados ao Sistema Universidade Aberta do Brasil: definições e prática docente. Revista Eletrônica Multidisciplinar Pindorama do Instituto Federal de Educação, Ciência e Tecnologia da Bahia - IFBA No 01 Ano I - - Agosto/2010. Disponível em: http://www.revistapindorama.ifba.edu.br/files/Ednaldo\%20Farias\%20Gomes\%20I FAL.pdf. Acesso em 20 de janeiro de 2015.

GONZALES, Mathias. Fundamentos da Tutoria em Educação a Distância. São Paulo: Editora Avercamp, 2005

HACKMAYER, Michelle Brust. BOHADANA, Estrella. O tutor na Educação a Distância: identidade, funções e ação docente. Anped-Sudeste, 2014. Disponível em https://anpedsudeste2014.files.wordpress.com/2015/05/michellebrust-hackmayer-estrella-bohadana.pdf. Acesso em 20 de janeiro de 2016. 
LAKATOS, Eva Maria; MARCONI, Marina de Andrade. Fundamentos de Metodologia Científica. 6. ed.Sao Paulo: Atlas, 2007.

LAPA, Andrea; PRETTO, N. de L. Educação a Distância e precarização do trabalho docente. Aberto, Brasília 23.84 (2010): 79-97.

LAPA, Andrea; PRETTO, Nelson De Luca. "Educação a distância e precarização do trabalho docente" Em Aberto, Brasília, v. 23, n. 84, p. 79-97, nov. 2010.

MACHADO, Lidiane. D.; MACHADO, E. C. O papel da tutoria em ambientes de EAD. São Paulo: Associação Brasileira de Educação a Distância, 2004. Disponível em: http://www.abed.org.br/congresso2004/por/htm/022-TC-A2.htm Acesso em: 08/07/2015.

MACHADO, M.F. Diálogo entre Metodologias Quantitativas e Qualitativas no Campo da Saúde. Documento produzido em 21/04/2011. Disponível em: www.psicologia.pt.

MASETTO, M. Novas Tecnologias e Mediação Pedagógica. Campinas, SP: Papirus, 2000.

MENDES, Valdelaine. O tutor no ensino a distância: uma forma de precarização do trabalho docente? R. Educ. Públ. Cuiabá, v. 22, n. 51, p. 855877, set./dez. 2013.2 Disponível em: http://periodicoscientificos.ufmt.br/index.php/educacaopublica/article/viewFile/12 61/1013. Acesso em 22 de novembro de 2015.

MILL, Daniel R. S, RIBEIRO, Luis Roberto C, Oliveira, M.R.G. Polidocência na Educação a Distância: múltiplos enfoques, São Carlos: EdUFSCar, 2010.

MILL, Daniel R, PIMENTEL, Nara Maria. Educação a Distância: desafios contemporâneos, São Carlos: EdUFSCar, 2010.

MILL, Daniel Ribeiro, Santiago, F. Carla; VIANA, Inajara de Salles. Trabalho docente na Educação a Distância: condições de trabalho e implicações trabalhistas. Revista extra-classe, N1-V1, Fevereiro, 2008.

MILL, D. (2012) Docência virtual: uma visão crítica. Campinas: Papirus. MILL, Daniel, ABREU E LIMA, Denise; Lima, S. Valéria; TANCREDI, Regina M. S. P. O desafio de uma interação de qualidade na Educação a Distância: o 
tutor e sua importância nesse processo. Cadernos da Pedagogia - Ano 2 Volume, 2 Número 4, agosto/dezembro 2008.

MILL, D.; FIDALGO, F. Sobre tutoria virtual na Educação a Distância: caracterizando o teletrabalho docente. Virtual Educa 2007, São José dos Campos, 2007. Disponível em: http://reposital.cuaed.unam.mx:8080/jspui/bitstream/123456789/1472/1/236DM.PDF. Acesso em 02 dez. 2015.

MINAYO, M.C. de S. (2010). O desafio do conhecimento: Pesquisa Qualitativa em Saúde. (12 a edição). São Paulo: Hucitec-Abrasco.

MOON, Bob. O papel das novas tecnologias da comunicação e da Educação a Distância para responder à crise global na oferta e formação de professores: uma análise da experiência de pesquisa e desenvolvimento. Educação e Sociedade, vol.29, n.104, 2008, p. 791-814.

MOORE, Michael G.; KEARSLEY, Greg. Educação a Distância: uma visão integrada. Tradução Roberto Galman. São Paulo: Thompson Learning, 2007.

NEVES, Viana de Salles Inajara; FIDALGO, Fernando Selmar. Docente virtual na Educação a Distância: condições de trabalho na rede privada de ensino. FAE-UFMG, 2008. Anais do I Seminário Nacional de Educação Profissional e Tecnológica -UFMG, 2008.

NUNES, Vanessa Battestin. O papel do tutor na educação a distância: o estado da arte. ESUD 2013 - X Congresso Brasileiro de Ensino Superior a Distância Belém/PA, 11 - 13 de junho de 2013 - UNIREDE. Disponível em: http://www.aedi.ufpa.br/esud/trabalhos/oral/AT2/114143.pdf. Acesso em 19 de set. 2014.

OLIVEIRA, Eloiza da Silva Gomes de; DIAS, Alessandra Cardoso Soares; FERREIRA, Aline Campos da Rocha. A importância da ação tutorial na Educação a Distância: discussão das competências necessárias ao tutor. Disponível em: http://www.niee.ufrgs.br/ribie2004/trabalhos/comunicações/com20-28.pdf. Acesso em: 19 set.2014. 
OLIVEIRA, Luciana Charão de. SANTOS, Adriana Cristina Omena do. A tutoria no curso de pedagogia a distância da universidade federal de Uberlândia: um estudo sobre condições de trabalho e prática docente ENPED. São Carlos, UFSCar: 2014.

PRETI, Oreste. O estado da arte sobre "tutoria" e modelos e teorias em construção. Programa CAERENAD- Télé-université du Québec, Canadá, agosto 2003. Dsponível em: http://uab.ufmt.br/uploads/pcientifica/tutoria_estado_arte.pdf. Acessado em: 23 de dezembro de 2015.

PALERMO, Roberta Rossi Oliveira. Formação e identidade do professor tutor no ensino superior na modalidade a distância: o percurso de uma pesquisa ENPED. São Carlos, UFSCar: 2014.

PERRENOUD, Philippe. A teoria das Competências. 1999. Disponível <http://www2.videolivraria.com.br/pdfs/14867.pdf >. Acesso em: 1 fev. 2016. PERRENOUD, Philippe et al. As competências para ensinar no século XXI. Porto Alegre: Artmed, 2002.

PIMENTEL, Fernando Silvio Cavalcante Pimentel. Interação On-line: um desafio da tutoria -Educação a Distância e educação on-line, Maceió: EDUFAL, 2013.

PIMENTEL, Fernando Silvio Cavalcante Pimentel, VIDAL, Odaléa F; BORBA, Sara Ingrid. Sob o Olhar da tutoria - Educação a Distância e Educação online 2, Maceió: EDUFAL, 2013.

PRETI, O. Educação a Distância: uma prática educativa mediadora e mediatizada. In: (org.). Educação a Distância: inícios e indícios de um percurso. Cuiabá: EdUFMT, 1996. P. 15-56.

SANTOS, Jader Camposdos; CUNHA, Anderson Leonardo da Silva; PEREIRA, Júlio H. da Silva. A identidade do professor-tutor na Educação a DistânciaENPED. São Carlos, UFSCar: 2014. Disponível em: www.siedenped2014.ead.ufscar.br/ojs/index.php/2014/article/.../202. Acesso em 16 de fevereiro de 2016. 
SANTOS, Mariana Estevam Camilo dos. WINCHUAR, Marcio José de Lima. O passo a passo do professor e do tutor de referência na EAD. ESUD 2014 - XI Congresso Brasileiro de Ensino Superior a Distância. UNIREDE. Florianópolis/SC, $05-08$ de agosto de 2014. Disponível em: http://esud2014.nute.ufsc.br/anais-esud2014/files/pdf/128182.pdf. Acesso em 17 de fevereiro de 2016.

SANTOS, Camila Silva Sousa. Entre a forma, a formação e a transformação: O que pensam os coordenadores sobre qualidade no curso de Pedagogia na modalidade a distância. Dissertação de Mestrado - PUC - Rio, 2015.

SILVA, Marco. Cibercultura e educação: a comunicação na sala de aula presencial e online. Revista Famecos. Porto Alegre, n 37, dez. de 2008. Disponível em: file:///C:/Users/Erika\%20Lins/Downloads/4802-15354-1-PB.pdf. Acesso em 10 de janeiro de 2016.

SILVA, Karina Bernardes de Oliveira e; QUARTIERO, Elisa Maria. Educação a Distância e identidade docente - Esud 2013 - X Congresso Brasileiro de Ensino Superior a Distância, Belém/PA, 11 - 13 de junho de 2013 - UNIREDE.

SCHMID. A. M. Tutorías: losrostros de la educación a distancia. Educação e Contemporaneidade. Revistas da FAEEBA. Vol 13, n.22, jul/dez, 2004, p.275285.

TARDIF, Maurice. Saberes docentes e formação profissional. Petrópolis, RJ: Vozes, 2002.

TARDIF, Maurice; RAYMOND, Danielle. Saberes, tempo e aprendizagem do trabalho no magistério. Educação e Sociedade. 2000, vol.21, n.73, pp. 209-244. ISSN 1678-4626.

TENÓRIO, André; JÚNIOR, José Ferrari; TENÓRIO, Thaís. A visão de tutores sobre o uso de fóruns em cursos a distância. Associação Brasileira de Educação a Distância - Volume 4, 2015.

TONNETTI, Flávio Américo. Tutor é professor: algumas considerações sobre o trabalho docente na educação a distância. SIED-ENPED. UFSCar, 2012.

VILLARDI, R.; OLIVEIRA, E. G. Tecnologia na Educação : uma perspectiva sócio-interacionista. Rio de Janeiro : Dunya, 2005. 
VILLARDI, R.; OLIVEIRA, E. G. Tecnologia na Educação: uma perspectiva sócio-interacionista. Rio de Janeiro: Dunya

VILARINHO, Lúcia Regina Goulart; CABANAS, Maria Imaculada Chao. Educação a Distância (EAD): o tutor na visão de tutores. Revista Educação, Santa Maria, v. 33 - set./dez. 2008. 
7

\section{Apêndices}

\section{Apêndice A: Termo de Consentimento Livre e Esclarecido}

\section{Termo de Consentimento Livre e Esclarecido}

Prezado (a) professor (a) tutor (a),

Solicito o preenchimento deste questionário que é parte integrante do levantamento de dados para a minha dissertação de mestrado intitulada "Tutor, professor ou suporte virtual? Um estudo sobre identidade profissional em construção no contexto da Educação a Distância".

A dissertação tem como objeto de análise a compreensão da figura do tutor, suas especificidades e o delineamento da sua identidade profissional. Em função disso, solicito sua valiosa colaboração ao responder às questões apresentadas a seguir, levando cerca de, no máximo, 15 minutos para responder o questionário.

Sua participação voluntária é muito importante.

Os dados coletados nesse estudo serão confidenciais, sendo o sigilo assegurado, quando da apresentação dos resultados em publicação científica, uma vez que os resultados da pesquisa serão sempre apresentados em um contexto de grupo e não individual. Você poderá se recusar a responder algumas das questões, ou retirar-se da pesquisa a qualquer momento, não havendo nenhum prejuízo pessoal.

O preenchimento e envio das suas respostas só poderá ser efetivado com a concordância do participante em relação a este termo de consentimento livre e esclarecido sobre a pesquisa.

Não é necessário se identificar, a não ser que deseje fazê-lo.

Agradeço a sua contribuição para a pesquisa.

Érika de Paula Lins.

erikaplins@gmail.com

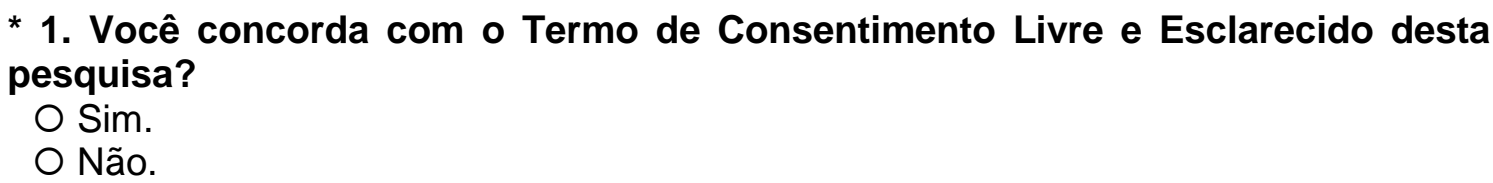


Apêndice B: Questionário aplicado

Questionário Tutor, professor ou suporte virtual?

Bloco 1: Perfil do tutor, experiência profissional e formação acadêmica

* 2. Sua função como tutor (a) é:

O presencial

à distância

* 3. Qual é a sua idade?

* 4. Qual a sua formação acadêmica?

$\square$ Graduação

$\square$ Especialização

$\square$ Mestrado

Doutorado

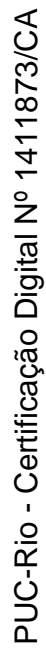

Utilize esse espaço para dizer qual(is) curso(s) você concluiu.

* 5. Você realizou formação Específica em EaD?

O Sim.

O Não.

\section{Comentários}

* 6. Há quanto tempo você trabalha como tutor (a)?

* 7. Além de trabalhar como tutor (a) você possui outra atividade profissional?

O Sim.

O Não.

Comentários 
Questionário Tutor, professor ou suporte virtual?

Bloco 2: Práticas predominantes no trabalho de tutoria

* 8. Conhece o projeto político-pedagógico do seu curso?

O Sim

○ Não

Comentários

\section{* 9. A seguir posicione-se sobre cada item de acordo com a sua experiência como tutor.}

Nunca Poucas Muitas Sempre

Com que frequência você percebe em sua interação com os alunos que os mesmos apresentam uma postura autônoma em relação ao processo de aprendizagem?

Com que frequência a interação com os alunos está voltada para os temas específicos da sua disciplina? Com que frequência você utiliza com os alunos vídeos, livros digitais e revistas eletrônicas para ampliar a discussão sobre os temas da disciplina? $\mathrm{Na}$ sua interação com os alunos, as questões relacionadas ao universo acadêmico-administrativo do curso aparecem com qual frequência? (Ex: prazos de envio de trabalho, notas, datas de provas, problemas gerais na plataforma, documentos e etc.) Com que frequência você contribui na construção das avaliações presenciais e a distância?

vezes vezes

000

$+2$

0

O 0

Com que frequência você participa do planejamento de trabalhos e atividades acadêmicas da disciplina que você atua?

Com que frequência você participa da construção do ambiente virtual da disciplina que você atua, na produção, avaliação, seleção e definição de estratégias de uso dos materiais utilizados?

Você costuma utilizar as ferramentas da Plataforma do Cederj durante o seu trabalho de tutoria? (Exemplos: o portal Teca, ambiente de avisos, email do Cederj, Wiki e etc.)

\section{Comentários}


Questionário Tutor, professor ou suporte virtual?

\section{Bloco 3: Percepções do tutor sobre o lugar que ele ocupa na Educação a}

* 10. Indique sua concordância para cada item abaixo de acordo com a sua experiência como tutor.

$\begin{array}{cccc}\text { Discordo } & \text { Discordo } & \text { Concordo } & \text { Concordo } \\ \text { totalmente } & \text { parcialmente } & \text { parcialmente } & \text { totalmente }\end{array}$

\begin{tabular}{|c|c|c|c|c|}
\hline $\begin{array}{l}\text { Sente-se responsável pelo } \\
\text { desempenho e desenvolvimento dos } \\
\text { alunos na disciplina em que você } \\
\text { atua. }\end{array}$ & 0 & 0 & 0 & 0 \\
\hline $\begin{array}{l}\text { Participa da tomada de decisões } \\
\text { concernentes ao planejamento da sua } \\
\text { disciplina. }\end{array}$ & 0 & 0 & 0 & 0 \\
\hline $\begin{array}{l}\text { Percebe a sua função com clareza, } \\
\text { no que se refere aos limites de } \\
\text { atuação das práticas de tutoria. }\end{array}$ & 0 & 0 & 0 & 0 \\
\hline $\begin{array}{l}\text { Sente-se valorizado pela instituição à } \\
\text { qual você exerce o trabalho de tutoria. }\end{array}$ & 0 & 0 & 0 & 0 \\
\hline $\begin{array}{l}\text { Sente-se valorizado pelos alunos do } \\
\text { seu curso. }\end{array}$ & 0 & 0 & 0 & 0 \\
\hline $\begin{array}{l}\text { Percebe a sua função como condição } \\
\text { primordial para a efetivação do } \\
\text { processo de ensino-aprendizagem do } \\
\text { seu curso. }\end{array}$ & 0 & 0 & 0 & 0 \\
\hline $\begin{array}{l}\text { Sente-se satisfeito com o formato de } \\
\text { vínculo de trabalho entre você a } \\
\text { instituição em que você atua. }\end{array}$ & 0 & 0 & 0 & 0 \\
\hline $\begin{array}{l}\text { Percebe a função do tutor como } \\
\text { funcão docente. }\end{array}$ & 0 & 0 & 0 & 0 \\
\hline
\end{tabular}

\section{Comentários}

* 11. Comente algo que você considere relevante na sua função como tutor.

* 12. Você acredita que ser tutor é uma profissão? 


\section{Questionário Tutor, professor ou suporte virtual?}

\section{Agradecimento}

O questionário chegou ao fim.

Obrigada pela sua contribuição nesta pesquisa.

Vale lembrar que os resultados serão utilizados para fins exclusivamente acadêmicos e o sigilo da sua participação será garantido.

Caso você tenha o interesse de conhecer o trabalho final, basta entrar em contato através do e-mail abaixo.
Atenciosamente,
Érika de Paula Lins.
erikaplins@gmail.com 


\section{Anexo A: Tabelas das respostas sobre o item: "Comente algo que você considere relevante na sua função como tutor".}

\begin{tabular}{|c|}
\hline COMENTE ALGO QUE VOCÊ CONSIDERE RELEVANTE NA SUA FUNÇÃO COMO TUTOR. \\
\hline $\begin{array}{l}\text { 1. Desenvolvimento de profissionais nas mais diversas localidades, disseminando o } \\
\text { conhecimento. }\end{array}$ \\
\hline $\begin{array}{l}\text { 2. A bolsa que recebemos é uma vergonha. Nosso compromisso com o CEDERJ acaba } \\
\text { sendo ruim por causa disso. Não temos valor. E às vezes nem recebemos e } \\
\text { trabalhamos de graça. }\end{array}$ \\
\hline $\begin{array}{l}\text { 3. A importância da tutoria é incontestável. Sem ela, os coordenadores de disciplina } \\
\text { estariam em apuros, isto é, limitados na sua atuação profissional enquanto um } \\
\text { docente que busca praticar um ensino digital de qualidade. }\end{array}$ \\
\hline $\begin{array}{l}\text { 4. A importância de reduzir a distância entre aluno e Instituição de Ensino, mostrando que } \\
\text { mesmo à distância existem pessoas neste processo. }\end{array}$ \\
\hline $\begin{array}{l}\text { 5. A importância saber interagir com os alunos de forma a motivar, orientar e despertar o } \\
\text { estímulo a aprendizagem autônoma dos mesmos, utilizando-se de metodologias e } \\
\text { meios adequados para facilitar a aprendizagem. }\end{array}$ \\
\hline $\begin{array}{l}\text { 6. A mediação é instrumentos primordial na atuação de um tutor, haja vista a necessidade } \\
\text { de engajar permanentemente o aluno ao planejamento político-pedagógico do curso. }\end{array}$ \\
\hline 7. A participação ativa no crescimento dos alunos, no que tange a sua educação. \\
\hline 8. A possibilidade dos encontros possibilita a troca de conhecimento \\
\hline 9. A relação com os discentes. \\
\hline $\begin{array}{l}\text { 10. A tutoria eh hoje completamente dispensável para os gestores de Cederj. São mantidos } \\
\text { somente devido às aulas práticas obrigatórias e aplicação de Ap's. (Avaliação } \\
\text { presencial). }\end{array}$ \\
\hline $\begin{array}{l}\text { 11. A tutoria possui sua relevância na orientação cientifica na construção do entendimento } \\
\text { dos conteúdos abordados e também serve como intermédio para evolução } \\
\text { institucional para o melhoramento das praticas de ensinos e avaliação. }\end{array}$ \\
\hline $\begin{array}{l}\text { 12. Acompanhamento e orientação não só acadêmicas bem como profissionais e pessoais. } \\
\text { Interação vital para o bom funcionamento do projeto de ensino e referência de } \\
\text { contato humano para os estudantes }\end{array}$ \\
\hline 13. Acredito que mudança de nomenclatura para professor on-line. \\
\hline $\begin{array}{l}\text { 14. Apesar de ser uma função relativamente nova, o tutor é importantíssimo para os alunos } \\
\text { de cursos na modalidade EAD. }\end{array}$ \\
\hline $\begin{array}{l}\text { 15. Após sete anos atuando como tutor a distância, percebo que é uma figura } \\
\text { imprescindível para que se estabeleça o processo de ensino e aprendizagem dentro da } \\
\text { EAD. Os tutores funcionam como uma alavancagem do curso e fazem o intercâmbio } \\
\text { entre os discentes e coordenadores de disciplina. Portanto, o coordenador que abre } \\
\text { espaço para o seu tutor participar das tomadas de decisões da disciplina, torna o seu } \\
\text { ambiente de aprendizagem mais enriquecedor, pois os tutores conhecem a realidade } \\
\text { diária dos alunos. }\end{array}$ \\
\hline
\end{tabular}




\begin{tabular}{|c|}
\hline $\begin{array}{l}\text { 16. Cada curso ou Universidade é de um jeito. No meu curso, o coordenador não sabia } \\
\text { nada de EAD no início e continua não sabendo hoje. O curso é o mesmo há } 10 \text { anos. }\end{array}$ \\
\hline $\begin{array}{l}\text { 17. Como tutor presencial não posso abrir mã das funções de professor. Antes de ser tutor } \\
\text { sou um professor, portanto é necessário rever sempre a minha prática pedagógica } \\
\text { oferecendo aos alunos os meios para alcançar os objetivos propostos. }\end{array}$ \\
\hline 18. Conhecimento do conteúdo e ser carismático. \\
\hline $\begin{array}{l}\text { 19. Dado a quantidade de alunos, que não podem se atendidos diretamente pelo professor, } \\
\text { que alguém disponível praticamente o dia todo, é muito importante. }\end{array}$ \\
\hline $\begin{array}{l}\text { 20. Deve ser valorizado, reconhecido como verdadeiro professor. Pois o tutor desempenha } \\
\text { por completo a função de professor. Inclusive na fundação CECIERJ ele não é um tutor } \\
\text { e sim o professor atuante. }\end{array}$ \\
\hline $\begin{array}{l}\text { 21. É o elo entre aluno e professor, exercendo papel importantíssimo no processo ensino- } \\
\text { aprendizagem. Pouco valorizado em todo o país. }\end{array}$ \\
\hline $\begin{array}{l}\text { 22. É relevante a humanização da educação, incentivando e estimulando o progresso dos } \\
\text { alunos. }\end{array}$ \\
\hline 23. EMPATIA \\
\hline 24. Ensinar \\
\hline $\begin{array}{l}\text { 25. Estimular e incentivar os alunos na continuação até a conclusão do curso de graduação, } \\
\text { auxiliando-os na fixação da aprendizagem e percebendo as limitações de cada um, } \\
\text { auxiliando-os pedagogicamente. Contribuir para que o aluno não se sinta isolado, por } \\
\text { ser um curso a distância. }\end{array}$ \\
\hline 26. Estímulo ao aluno. \\
\hline 27. Falta integração entre tutores presenciais e os professores \\
\hline 28. Fomentar a autonomia nos estudos da disciplina. \\
\hline 29. Formação e avaliação permanente \\
\hline $\begin{array}{l}\text { 30. Grande parte dos alunos que passam por mim estão tendo o primeiro contato com a } \\
\text { EaD. Nesse passo, os contatos iniciais são de grande relevância, pois auxiliam os alunos } \\
\text { a melhor compreender esse sistema de ensino e a se acostumar com ele. }\end{array}$ \\
\hline $\begin{array}{l}\text { 31. Há muito caminho a ser perseguido, mas observo que não somos valorizados como } \\
\text { deveríamos e somos extremamente responsáveis pela construção do conhecimento, } \\
\text { pois somos a representação da universidade na vida do aluno, no entanto o consorcio } \\
\text { criou um método que nos distancia do valor real de nossa atribuição. }\end{array}$ \\
\hline 32. Interação com os alunos \\
\hline 33. Interação contínua com os alunos \\
\hline 34. Mediação \\
\hline 35. Mediação e motivação dos alunos. \\
\hline 36. Não \\
\hline $\begin{array}{l}\text { 37. Nosso contato com o aluno é primordial para situá-lo na modalidade de ensino EAD. } \\
\text { Percebo os alunos muito perdidos na hora de resolver questões relevantes como } \\
\text { dúvidas de conteúdo, revisão de nota, discussão de gabarito de prova, etc. }\end{array}$ \\
\hline $\begin{array}{l}\text { 38. O contato com o aluno é primordial para a transição do aluno que estava acostumado } \\
\text { com o ensino presencial e se depara com uma graduação EAD. }\end{array}$ \\
\hline $\begin{array}{l}\text { 39. O fato de estar diretamente em contato com os alunos, o que em algumas disciplinas } \\
\text { acaba sendo bem mais do que o próprio coordenador da disciplina. Destaca-se, ainda, } \\
\text { que alguns professores sequer contatam seus alunos ou a Plataforma. Acho } \\
\text { importante na função do tutor quando ele interage com os alunos, dando-lhes } \\
\text { feedback sobre suas atividades, conduta, comentários, etc, bem como, interessando-se } \\
\text { pelo aluno ou por sua ausência, seja em atividades, provas, fóruns. }\end{array}$ \\
\hline $\begin{array}{l}\text { 40. O papel de educar, de transmissão de conhecimento em um sistema inovador e de } \\
\text { grande interatividade. }\end{array}$ \\
\hline 41. O processo de mediação entre o ambiente e o aluno \\
\hline $\begin{array}{l}\text { 42. O trabalho conjunto com toda coordenação e a utilização de outras ferramentas para a } \\
\text { melhor compreensão dos alunos. }\end{array}$ \\
\hline
\end{tabular}




\begin{tabular}{|c|}
\hline $\begin{array}{l}\text { uma dúvida respondida auxilia tanto no aprendizado quanto na fixação do conteúdo - } \\
\text { assim, a função do tutor é relevante no na aquisição do conhecimento. }\end{array}$ \\
\hline 44. O tutor e a ponte entre o aluno e a disciplina e tem a função estimular esse circulo. \\
\hline $\begin{array}{l}\text { 45. O tutor é fundamental no processo de ensino aprendizagem dos alunos, especialmente } \\
\text { na modalidade a distância. }\end{array}$ \\
\hline 46. O tutor é o vínculo entre o aluno e o curso \\
\hline $\begin{array}{l}\text { 47. O tutor tem a função primordial para direcionar os alunos nos conteúdos das } \\
\text { disciplinas. }\end{array}$ \\
\hline $\begin{array}{l}\text { 48. O tutor tem pouca autonomia na construção da avaliação do aluno, apesar de ter mais } \\
\text { contato direto com o aluno. }\end{array}$ \\
\hline 49. Orientação \\
\hline $\begin{array}{l}\text { 50. Para o tutor presencial é necessário o conhecimento de atuar em sala de aula, pois o } \\
\text { aluno não exige do tutor uma tutoria, mas sim uma aula de nível universitário, que } \\
\text { procuro fornecer adequadamente para a qualidade do curso e satisfação minha e dos } \\
\text { alunos. }\end{array}$ \\
\hline 51. Remuneração incompatível com as atividades desenvolvidas. \\
\hline 52. Ser facilitador do processo de ensino-aprendizagem. \\
\hline 53. Ser o referencial do aluno no processo de adaptação ao ensino à distância. \\
\hline $\begin{array}{l}\text { 54. Ser um artista e fazer com que a aula pule pra fora do monitor, a fim de promover o } \\
\text { estímulo do aluno. }\end{array}$ \\
\hline 55. Ter total domínio e conhecimento da disciplina e buscar contínuo aperfeiçoamento. \\
\hline $\begin{array}{l}\text { 56. Tornar possíveis os resultados de uma interação tutor/aluno, quase sempre tão } \\
\text { geograficamente distantes, visando a complementação do processo de aprendizagem. }\end{array}$ \\
\hline Total: 56 tutores respondentes \\
\hline
\end{tabular}

\section{Anexo B: Bloco final - Tabela das respostas da pergunta aberta "Você acredita que ser tutor é uma profissão"?}

\section{Você acredita que ser tutor é uma profissão?}

1. Acredito que o tutor é um docente.

2. Acredito que ser tutor é uma profissão que mereça a devida regulamentação e consequentes garantias de direitos trabalhistas, extinguindo, desta maneira, a condição fugaz e desvalorizada do bolsista.

3. Apoio o projeto de lei -> PL2435/2011, veja: 'Está em andamento na Câmara dos Deputados um projeto de lei a respeito da profissionalização de tutores em EAD: trata-se do PL2435/2011, que dispõe sobre a regulamentação do exercício da atividade de Tutoria em EaD.' fonte:<http://www.fe.unb.br/catedraunescoead/destaque/teste-2>

4. Claro.

5. Claro que sim, é uma forma de docência só que no ambiente virtual, o que é muito mais trabalhos e difícil.

6. Com certeza.

7. Com toda a certeza que se pode ter.

8. Concordo totalmente

9. Deveria ser, mas não é tida como na integra.

10. É uma missão - e das mais nobres!

11. Na minha opinião, o tutor é um professor e é uma profissão, assim como os professores em faculdades particulares, que é uma profissão.

12. Não, mas requer toda a responsabilidade na condução do processo de aprendizagem.

13. Não! Mas acho brevemente isto vai acontecer.

14. Não.

15. Participei de um treinamento no final do ano passado onde foi colocado que tutoria é atividade. Pode ser praticada por graduados, alunos de pós-graduação. Não é 


\begin{tabular}{|c|c|}
\hline & regulamentado como profissão e, por isso, não temos direitos trabalhistas. \\
\hline & Plenamente, sim \\
\hline 17. & Pode até ser, mas o tutor nada mais é que o professor auxiliar. \\
\hline 18. & Sem sombra de dúvida. \\
\hline & $\begin{array}{l}\text { Ser tutor é uma profissão, apesar de não reconhecida, mas ser tutor presencial, já é } \\
\text { docência. }\end{array}$ \\
\hline & Sim \\
\hline 21. & Sim \\
\hline 22. & Sim \\
\hline 23. & Sim acredito, mas infelizmente não é reconhecida e não tem os devidos valores. \\
\hline 24. & Sim, e de importância muito válida. \\
\hline 25. & Sim, acredito. \\
\hline 26. & Sim, atribuição similar ao do professor. \\
\hline 27. & Sim, com nomenclatura diferente. \\
\hline 28. & Sim, é como um professor facilitador. \\
\hline & Sim, é uma profissão. No entanto, não é reconhecida como tal pelas nossas autoridades. \\
\hline & $\begin{array}{l}\text { Sim, na minha concepção o tutor desempenha papel tão relevante na formação acadêmica } \\
\text { dos alunos quanto um professor. }\end{array}$ \\
\hline & Sim, plenamente. \\
\hline & Sim! \\
\hline 33. & Sim! É um professor/orientador \\
\hline 34. & Sim! Porém não reconhecida e nem remunerada justamente. \\
\hline 35. & Sim. \\
\hline & $\begin{array}{l}\text { Sim. Nós tutores somos tratados como uma categoria inferior aos professores. Mas, esta é } \\
\text { uma percepção errônea da tutoria. Considero-me uma PROFESSORA. Não possuo qualquer } \\
\text { formação pedagógica, mas, minha atuação como tutora é, pra mim, uma espécie de } \\
\text { atuação docente. }\end{array}$ \\
\hline 37. & Sim. O mundo da educação é outro. \\
\hline & $\begin{array}{l}\text { Sim. O tutor realiza diversas atribuições profissionais indispensáveis ao processo de } \\
\text { Educação a Distância. Sem eles, a atuação de professores e coordenadores de disciplina } \\
\text { estariam limitadas. Tutores são auxiliares/assistentes educacionais. Em qualquer área de } \\
\text { atuação, existem os cargos de assistência, como assistentes administrativos, sociais, } \\
\text { hospitalares, etc. A tutoria sendo uma continuação dessas assistências, só que voltada para } \\
\text { a área educacional, não deveria ser considerada uma profissão? }\end{array}$ \\
\hline & $\begin{array}{l}\text { Sim. Para os alunos dos cursos semipresenciais e/ou à distância, a figura do tutor em nada } \\
\text { difere da figura de um professor tradicional. }\end{array}$ \\
\hline & Total: 39 tutores respondentes \\
\hline
\end{tabular}

